\title{
TRIAL DISTORTION AND THE END OF INNOCENCE IN FEDERAL CRIMINAL JUSTICE
}

\author{
RONALD F. WRIGHT ${ }^{\dagger}$
}

INTRODUCTION 80

I. GUILTY PleAs That RESOLVE CASES BUT NOT QUESTIONS................ 87

A. Federal Guilty Plea Growth Spurts ..................................................... 88

B. Plea Bargain Theories, Looking High and Low ............................... 91

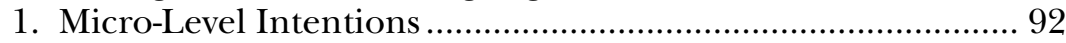

2. Macro-Level Social Purposes.................................................... 97

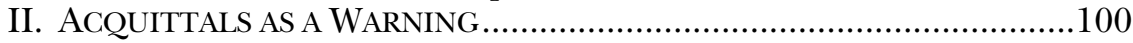

A. Federal Acquittal Rates and the Guilty Plea Connection ......................101

B. Acquittals and the Other Displaced Outcomes ...................................103

C. The Mid-Level Trial Distortion Theory............................................106

1. Trial Distortion and Trial Penalties......................................107

2. Are Lost Acquittals and Dismissals Trial Distortions?..............112

3. The Accuracy Hypothesis ...................................................114

III. WHAT MADE FEDERAL ACQUITTALS DISAPPEAR?..............................116

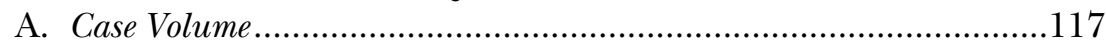

B. Legal Complexity and Defense Counsel in the 1950s and 1960 s........122

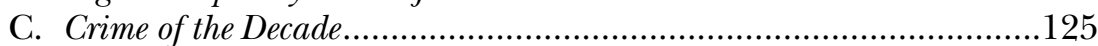

D. Sentence Severity and Trial Penalties in the 1990s............................129

E. Prosecutor Power as the Leading Acquittal Culprit ............................134

IV. LEGAL ENVIRONMENTS HOSTILE TO INNOCENCE ............................137

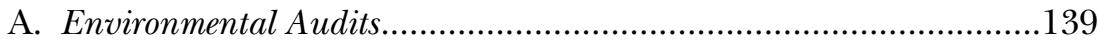

B. Trials and Tribulations by the Numbers ..........................................146

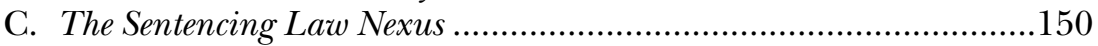

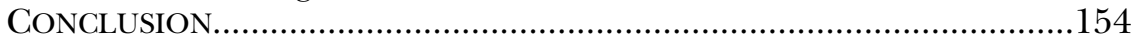

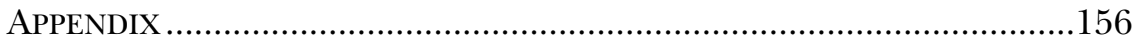

\footnotetext{
${ }^{\dagger}$ Professor of Law, Wake Forest University. My thanks go to my literate and numerate readers: Rachel Barkow, Stephanos Bibas, Steve Chanenson, Jennifer Collins, Michael Curtis, Nora Demleitner, Margareth Etienne, Richard Frase, Nancy King, Andrew Leipold, Kay Levine, Marc Miller, Michael O'Hear, Wendy Parker, Ralph Peeples, Suzanne Reynolds, Daniel Richman, Ahmed Taha, and Margaret Taylor.
} 


\section{INTRODUCTION}

Listen for a while to crime victims and you will hear both frustration and resignation about plea bargaining, but you will hear no true believers. Some crime victims sound relieved that the plea bargain spares them from the prolonged ordeal of a trial: as one woman put it, "I just want it over with." Others take comfort in the idea that a guilty plea holds the defendant responsible: "It's what we were looking for the last three years.... He admitted that he was involved and played a part." ${ }^{2}$ Some note that the plea eliminates any risk of acquittal at trial: "I know there are people out there who do far worse and get off for their crimes." ${ }^{3}$

Alongside these lukewarm endorsements, there are plenty of comments on the negative side of the ledger. Victims frequently say the punishment that the defendant received after a plea bargain was not what they expected, complaining about "a slap on the wrist."

\footnotetext{
${ }^{1}$ Gwen Filosa, Woman Changes Guilty Plea in Killing, Times-PiCAYUne (New Orleans), May 4, 2004, at B-1 (internal quotation marks omitted) (quoting a murder victim's mother after the alleged killer changed her guilty plea); see also Carol Demare, Victim at Peace with Boxley Plea Deal, Times UnION (Albany), Dec. 24, 2003, at B1 (quoting the sexual assault victim of a politically powerful defendant as saying, "[a]ctually, I was relieved that a plea bargain could be reached," and noting that she was "extremely nervous" about testifying).

${ }^{2}$ Thomasi McDonald, Parents Accept Wreck Penalty, News \& OBSERVER (Raleigh), July 2, 2004, at B1 (internal quotation marks omitted) (quoting a manslaughter victim's father, who was responding to the killer's acceptance of a plea bargain); see also Demare, supra note 1, at B1 (quoting the victim as saying, "I felt most importantly that Boxley be held accountable for what he did and [the plea] took care of that").

${ }^{3}$ Sarah Coppola, Sentence Has Some Victims Unhappy, Austin Am.-STATESMAn, July 1, 2004, at B1 (internal quotation marks omitted) (quoting a victim, familiar with the plea bargaining system through her employment with Child Protective Services, who was responding to the plea bargain accepted by a man guilty of improper photography).

${ }^{4}$ See, e.g., Alan Gomez, Delray Pastor To Serve No Time for Molestation, Palm Beach Post, June 25, 2004, at 1C (discussing the case of a pastor who received five years probation as punishment for sexually molesting a nine-year-old girl); see also, e.g., John Caher, Ex-Assembly Counsel Boxley Sentenced to a Misdemeanor, N.Y.L.J., Feb. 24, 2004, at 1 (quoting a sexual assault victim after her assaulter was sentenced only on a misdemeanor sex count); Coppola, supra note 3, at B1 (discussing the plea bargain of two years imprisonment accepted by a defendant who secretly videotaped 500 women in the dressing room of a gym); McDonald, supra note 2, at B1 (quoting a manslaughter victim's father who said, in response to a plea bargain of thirty-six months probation and a suspended license, "[B]asically there were no dire consequences"). For survey evidence about popular disapproval of plea bargaining, see Stanley A. Cohen \& Anthony N. Doob, Public Attitudes to Plea Bargaining, 32 CRIM. L.Q. 85, 103 (1989) (concluding that "[m] ost Canadians disapprove of the process of plea bargaining"); Patricia A. Payne, Plea Bargaining: A Necessary Evil?, in CRITICAL IsSUES IN CRIME AND JUSTICE
} 
Some question the judgment of prosecutors who are overly driven by a fear of losing or the emotional costs of a trial: "[The prosecutor] told me that if they went to trial and he gets acquitted, she couldn't live with that .... It's not for her to live with. It's for me." ${ }^{5}$ For others, the problem with a plea bargain is that it blocks the public from learning the full story of the defendant's crime: "it prevents all the facts from coming out." ${ }^{6}$ Worst of all, plea bargaining can pressure some defendants to accept convictions for crimes they did not commit. ${ }^{7}$

It is little wonder that crime victims demonstrate such contradictory, even confused, reactions to plea bargains. Those of us who study or work in criminal justice full-time are likewise conflicted and confused about the practice, and as a result we have not yet created adequate ways to change plea negotiations for the better.

Our current discussions of plea bargains offer little hope of improving matters because they take place either at too high or too low a level of abstraction. Sometimes we evaluate plea bargains at the case level. The trial judge asks whether a particular defendant entered a "knowing and voluntary" guilty plea, founded on some "factual basis."

232, 232 (Albert R. Roberts ed., 1994) (describing common public concerns regarding plea bargaining); Julian V. Roberts, Public Opinion, Crime, and Criminal Justice, in 16 Crime AND Justice: A Review OF RESEARCH 99, 149 (Michael Tonry ed., 1992) (discussing studies that have shown that a majority of Americans and Canadians disapprove of plea bargaining).

${ }^{5}$ See Gwen Filosa, Family of Dead Teen is Against Plea Deal, Times-PiCAYune (New Orleans), Apr. 6, 2004, at B-1 (internal quotation marks omitted) (quoting the mother of a homicide victim); see also Coppola, supra note 3, at B1 (noting the prosecutor's hesitation to try an alleged improper photographer in nine separate cases, in part because of the emotional drain on victims); Gomez, supra note 4, at 1C (quoting a victim who said that in offering a plea bargain, prosecutors were too preoccupied with the emotional toll a trial would put on her); Fred Lebrun, Courtroom Shift Spurs New Debate, Times Union (Albany), Feb. 24, 2004, at B1 (quoting the victim as saying, "I was eager to avoid a trial the district attorney's office said we could not win").

${ }^{6}$ See Rex Bowman, Former Law-School Student Gets Life for Three Slayings, RicHMOND Times-DisPATCH, Feb. 28, 2004, at A1 (internal quotation marks omitted) (quoting the attorney for students wounded by a shooter); see also Rose Dunn, Letter to the Editor, Plea Bargain Wasn't Punishment Enough, Home News TrIB. (East Brunswick, N.J.), Dec. 25, 2003, at A15 (responding to the plea bargain in an aggravated manslaughter case by asking, "Why was this case decided by two people instead of a jury?").

${ }^{7}$ See Daniel Givelber, Meaningless Acquittals, Meaningful Convictions: Do We Reliably Acquit the Innocent?, 49 RUTGERS L. REV. 1317, 1342 (1997) (“[A] rational [but innocent] defendant who is likely to be convicted may choose the lesser sentence resulting from a plea bargain rather than risk erroneous conviction.").

${ }^{8}$ For various formulations of the standards for factual basis, voluntariness, and knowledge, see FED. R. CRIM. P. 11(b) (2) ("Before accepting a plea of guilty . . . , the court must address the defendant personally in open court and determine that the plea is voluntary and did not result from force, threats, or promises (other than promises in a plea agreement)."); FED R. CRIM. P. 11(b) (3) ("Before entering judgment on a 
Any plea meeting this standard will be legally sound and will meet the approval of most judges and attorneys. Yet this standard that courts use to evaluate guilty pleas at the individual case level is anemic, since the facts supporting guilty pleas can be remarkably thin, and many "knowing" and "voluntary" guilty pleas are nevertheless coercive and unjust.

At other times, we evaluate plea bargaining at a very high level of abstraction, treating this disposition of criminal cases as a social institution that deserves our embrace, or our acquiescence, or our condemnation as a whole. Perhaps we should think of plea bargaining as a method of making criminal adjudication more efficient; ${ }^{9}$ perhaps instead we should consider it a squalid and unnecessary procedural shortcut. ${ }^{10}$ In any case, the point of thinking at this highest level of abstraction is to evaluate the impact of all plea bargains on criminal justice and on the social order.

This vantage point, considering plea bargaining as a social institution, delivers genuine insights about the practice, yet it is also enervating. Because no one will abolish plea bargains entirely from the American criminal courtroom, ${ }^{11}$ what we need is a regulatory strategy rather than further insights on the question of abolition. The caseand society-wide levels of analysis have not shown us where to regulate or how to sort the good plea bargains from the bad ones.

A mid-level theory would fit better with the current reality of plea bargaining in the United States and would best mark the road to reform. This sort of theory would allow us to analyze guilty pleas at the system level for each jurisdiction, recognizing that in some places plea bargain practices are relatively benign, while in others there is something amiss in bargain justice.

guilty plea, the court must determine that there is a factual basis for the plea."), and compare U.S. SENTENCING GUIDELINES MANUAL $\$ 6 B 1.2$ (a) (2004) ("[T] he court may accept [a charge bargain] if ... the remaining charges adequately reflect the seriousness of the actual offense behavior and ... accepting the agreement will not undermine the statutory purposes of sentencing or the sentencing guidelines.").

${ }^{9}$ See Frank H. Easterbrook, Criminal Procedure as a Market System, 12 J. LEGAL STUD. 289, 289 (1983) (arguing that plea bargaining is an element "of a well-functioning market system").

${ }^{10}$ See generally Stephen J. Schulhofer, Is Plea Bargaining Inevitable?, 97 HARV. L. REV. 1037, 1107 (1984) (arguing that plea bargaining is not inevitable and that it should not be preferred to a bench trial).

${ }^{11}$ See generally George Fisher, Plea Bargaining's Triumph, 109 YALE L.J. 857 (2000) (examining the development of plea bargaining into a dominant force in American criminal procedure). 
This Article develops a "trial distortion" theory as one possible mid-level evaluation of plea negotiation practices in particular systems. According to this theory, criminal courts in a jurisdiction produce too many dysfunctional guilty pleas when those guilty pleas distort the pattern of outcomes that would have resulted from trials. A healthy system would aspire to replicate through its guilty pleas the same pattern of outcomes that trials would have produced. Trial distortion theory calls attention to case outcomes rather than negotiations in progress, and to patterns across cases rather than practices in a single case.

Acquittals and dismissals play a starring role in the trial distortion story. These are cases that might have resulted in a defendant's freedom, and when a system starts to produce fewer acquittals and fewer dismissals, it triggers a warning light about the truth-finding function of the criminal justice system.

In some systems, further inquiry might show that a drop in the acquittal rate amounted to a false alarm, revealing no real basis for concern. According to a reassuring line of reasoning that I will call the "accuracy hypothesis," fewer acquittals might simply reveal a system that produces increasingly accurate outcomes. The accuracy might be achieved through a higher quality of cases entering the system, an improvement made possible when prosecutors make more time to screen more carefully the cases referred to them. Perhaps law enforcement agents get better at collecting the evidence needed to win a case. Similarly, downward trends in the acquittal rates might merely reflect better trial preparation and performance by prosecutors, or better negotiating skills among all the attorneys.

In some other systems, however, a drop in the acquittal rate could point to very real problems with the quality of criminal justice. Lower acquittal rates might show that prosecutors sell difficult cases too cheaply and only take easy cases to trial. On the other hand, lower acquittal rates might indicate that defendants sell too cheaply, either because timid or underfunded defense attorneys cannot or will not challenge the prosecutor's weakest cases, or (the most chilling possibility) because the judge and the prosecutor threaten the defendant with too great a penalty for going to trial. ${ }^{12}$

\footnotetext{
${ }^{12}$ In addition, a long-term drop in the rate of acquittals might become worrisome when acquittals no longer serve their market discipline function during plea negotiations. Acquittals at trials might become so rare that they cannot check abuses during bargaining. See Stephanos Bibas, Plea Bargaining Outside the Shadow of Trial, 117 HARV. L. REV. 2463, 2470-76 (2004) (discussing the problematic incentives of prosecutors in plea negotiations that do not reflect expected trial outcomes); Gerard E. Lynch, Our
} 
It is only possible to choose between these theoretical possibilities-the trial distortion theory and the accuracy hypothesis-by observing particular criminal justice systems at work; accordingly, this Article interprets the patterns of guilty pleas and acquittals in the federal criminal justice system. ${ }^{13}$ Acquittals are steadily disappearing from the federal system. Indeed, acquittals are disappearing more quickly than any other outcome, including trial convictions and dismissals, as guilty pleas expand to displace all other outcomes in federal court. The drop in acquittals over the last thirty years flags some serious doubts about the quality of justice in the federal system today. $^{14}$

A close look at the system tells us that increasing accuracy probably does not explain this trend; unfortunately, the pattern has unfolded because federal prosecutors have accumulated so much power under the sentencing laws that they can punish defendants too severely for going to trial. Federal law must respond to the current distorting form of plea negotiations by restoring counterbalances to prosecutorial bargaining power and by limiting the techniques available to reward defendants for waiving their trials.

Part I of this Article reviews the underappreciated history of guilty plea rates in the federal criminal justice system. Surprisingly, federal guilty plea rates stayed flat during some periods and even declined significantly during the 1950 s and 1960s. After a relentless climb from the early 1970 s to the present, however, the most recent numbers show the highest rates of guilty pleas in the history of federal criminal justice. Part II documents how acquittal rates moved down whenever guilty plea rates went up. In fact, since 1971 acquittal rates have dropped faster than other outcomes, such as dismissals or trial convictions.

Administrative System of Criminal Justice, 66 FORDHAM L. REV. 2117, 2146 (1998) ("[F]ully-adjudicated cases may be too rare to serve as a meaningful check on the executive authorities.").

${ }^{13}$ To evaluate these patterns, I have compiled the relevant data in a web-based Statistical Appendix for this Article, available at http://ssrn.com/abstract=809124 [hereinafter Statistical Appendix]. Unless otherwise noted, the Statistical Appendix is the source for the data in this Article's tables and figures.

${ }^{14}$ In 1975, Michael Finkelstein pursued this insight about the importance of acquittals and dismissals in the evaluation of guilty pleas in a path-breaking statistical analysis of federal criminal justice. Michael O. Finkelstein, A Statistical Analysis of Guilty Plea Practices in the Federal Courts, 89 HARV. L. REV. 293 (1975). For a discussion of the intellectual debt I owe Finkelstein, and the limitations of his approach, see infra note 74 . 
What explains the disappearance of acquittals in recent decades? In Part III we look for answers based in the history of federal criminal justice. Shifts in the types of crimes charged explain some of the patterns. The strengthened presence of defense counsel accounts for the declining guilty plea rate in the 1950s and 1960s. However, the most important cause of rising guilty pleas and falling acquittals in recent decades has been a dramatic increase in prosecutorial resources. Surprisingly, federal prosecutors today handle far fewer cases per attorney than they did in the middle of the twentieth century.

Part IV pursues a deeper inquiry into federal plea practices, concentrating on more recent years. Building on the premise that each of the ninety-four federal judicial districts employs its own plea practices with distinctive side effects, I analyze district-level statistics from 1994 to the present to determine which environmental factors most strongly affect both guilty pleas and acquittals.

This study points toward a symbiosis between plea practices and sentencing law. The federal system over the last three decades has featured increasingly severe sentences, and the adoption of federal sentencing guidelines in the late 1980s enhanced the power of prosecutors and judges to reward cooperation from defendants. In those districts where prosecutors took full advantage of the tools available to them under the sentencing laws, it became more expensive than ever for a federal defendant to insist on a trial; fewer paid the price each year.

Two of the most important tools used to increase the plea discount were "substantial assistance" departures that rewarded defendants with lighter sentences for cooperating with the government to develop cases against other defendants, ${ }^{15}$ and "acceptance of responsibility" adjustments to lighten the sentences of defendants who pled guilty early and gave the government full information about their crimes. ${ }^{16}$ The real power of these tools becomes clear when we notice that districts making heavy use of these techniques produced both higher guilty plea rates and lower acquittal rates. In those districts,

${ }^{15}$ See U.S. SENTENCING Guidelines Manual § 5K1.1 (2004) ("Upon motion of the government stating that the defendant has provided substantial assistance in the investigation or prosecution of another person who has committed an offense, the court may depart from the guidelines.").

${ }^{16}$ See id. \$3E1.1 (mandating the reduction of a defendant's offense level "[i]f the defendant clearly demonstrates acceptance of responsibility for his offense," and under some circumstances, if "the defendant has assisted authorities in the investigation or prosecution of his own misconduct by timely notifying authorities of his intention to enter a plea of guilty"). 
the trial penalty-that is, the differential between the sentence after plea and sentence after trial-convinced more defendants to abandon worthwhile defenses. In short, the combination of charging and sentencing options gave federal prosecutors the power to distort trial outcomes.

Having identified some features of the federal legal landscape that contribute to the most distorting plea negotiation practices, can we put these discoveries to work? Is reform possible? These questions achieved new urgency in early 2005, when the Supreme Court threw federal sentencing out of kilter with its decision in United States $v$. Booker. ${ }^{17}$ It was immediately clear that federal sentencing would never be the same after this case. Congress began considering ways to repair the broken system, and key legislators pronounced this to be a moment for serious rethinking of the federal sentencing system. ${ }^{18}$

In this rare time of reflection and redesign, the effects of sentencing rules on plea negotiation practices should remain at the center of our attention. When we judge plea negotiations by the patterns of outcomes they produce, they reveal the importance of two avenues for reform. First, sentencing rules need to check the monopoly power of prosecutors over key sentencing discounts. The judge needs credible authority to override prosecutorial decisions that punish defendants too severely when they insist on a trial. Second, sentencing reforms must keep within tolerable bounds the penalty that a defendant must pay for going to trial, whether the prosecutor or the judge is the source of that penalty. Sentencing reforms moving in these directions will both restore a balance of powers in federal criminal justice and improve the accuracy of the system. Federal sentencing should become more a servant of truth and less a slave to efficient case disposition.

${ }^{17} 125$ S. Ct. 738, 756 (2005) (holding that any facts that increase the maximum available sentencing range must be found by the jury rather than the sentencing judge); see also Blakely v. Washington, 124 S. Ct. 2531, 2536 (2004) (holding similarly to Booker, but with respect to state sentencing guidelines).

${ }^{18}$ See Posting of Douglas A. Berman to Sentencing Law and Policy, Panel 1 Sentencing Hearing Highlights, http://sentencing.typepad.com/sentencing_law_and_ policy/2004/07/panel_1_senate_html (July 13, 2004, 11:53 AM) (describing the statements of senators in the hearing of the Senate Judiciary Committee on "Blakely $v$. Washington and the Future of the Federal Sentencing Guidelines"). See generally Posting of Douglas A. Berman to Sentencing Law and Policy, The House Hearing and Data Versus Anecdote in Sentencing Policy-Making, http://sentencing.typepad.com/ sentencing_law_and_policy/2005/02/data_versus_ane.html (Feb. 10, 2005, 12:58 PM) (describing the hearing of the House Judiciary Committee on "The Implications of the Booker/Fanfan Decisions for the Federal Sentencing Guidelines"). 


\section{Guilty Pleas That Resolve Cases but not Questions}

High-quality criminal justice and guilty pleas can coexist under the right conditions. Nevertheless, for over a century, lawyers and judges in the United States have treated "high" levels of guilty pleas as a cause for concern.

The worries became more acute during times of change, when guilty pleas threatened to make the criminal trial disappear. For instance, in the 1920s, attorneys and academics studied criminal justice systems in many states and reported with alarm that criminal jury trials were vanishing. ${ }^{19}$ In many cities, the percentage of convictions obtained from guilty pleas exceeded $70 \%$-low figures by today's standards, but jarring to attorneys at the time. ${ }^{20}$ Concern about the loss of criminal trials picked up again in the late 1960s and 1970s. ${ }^{21}$

Although higher guilty plea percentages captured the headlines, times of growth were not constants. For example, we know that guilty pleas fell dramatically during several decades during the nineteenth century in Massachusetts. ${ }^{22}$ We know a lot about what sends guilty

${ }^{19}$ See, e.g., Alfred Bettman, Prosecution, in Cleveland Found., CRIMINAL Justice IN Cleveland 83, 95 tbl.3, 149, 181, 208 (Roscoe Pound \& Felix Frankfurter eds., 1922) (discussing the reasons, which included the prevalence of guilty pleas, for fewer trials); Hugh N. Fuller, Criminal Justice IN Virginia 79 tbl.39 (1931) (showing an increase in urban-jurisdiction guilty plea rates, out of those for whom guilt was established, from $50 \%$ in 1917 to $75 \%$ in 1927); C.E. Gehlke, Recorded Felonies: An Analysis and General Survey, in ILl. Ass'N FOR CRIMINAL Justice, The IllinOIS CRIME SURVEY 25, 42-46, 72-86 (John H. Wigmore ed., 1929) (providing reasons for "trial court eliminations" and discussing the impact of plea bargaining thereon); see also Albert W. Alschuler, Plea Bargaining and Its History, 79 ColuM. L. REV. 1, 26-32 (1979) (discussing the criminal justice surveys of the 1920s).

${ }^{20}$ See Raymond Moley, The Vanishing Jury, 2 S. CAL. L. REv. 97, 105 (1928) (showing that, of twenty-four jurisdictions surveyed, only three showed that less than $70 \%$ of convictions were obtained through guilty pleas and five showed that at least $90 \%$ were so obtained).

${ }^{21}$ See, e.g., Harry Kalven, JR. \& HANS Zeisel, The AmErican Jury 19-20 (1966) (assessing the reasons for guilty pleas); DONALD J. NEWMAN, CONVICTION: THE DETERMINATION OF GUILT OR INNOCENCE WiTHOUT TRIAL 3 (Frank J. Remington ed., 1966) ("Roughly 90 per cent of all criminal convictions are by pleas of guilty ...."); DALLIN H. OAKS \& WARREN LEHMAN, A CRIMINAL JUSTICE SYSTEM AND THE INDIGENT: A STUdy OF CHICAGO AND COOK COUNTY 59, 66 (1968) (providing tables illustrating guilty plea percentages in Chicago). See generally Alschuler, supra note 19 (reviewing studies of guilty plea rates).

${ }^{22}$ Our most complete information about nineteenth-century plea rates (and about early guilty plea practices more generally) comes from George Fisher's engaging history of the middle-tier criminal courts in Massachusetts. GEORGE FISHER, PLEA BARGAining's Triumph: A History OF Plea Bargaining in AMERICA (2003). Fisher also offers some useful breakdowns among different types of crimes, with distinctive movement in the rates for liquor sales crimes, murders, and other offenses. See, e.g., id. at 35 tbl.1.2 
plea rates up, but we could also profit from asking what sends them sideways or down. Just as we can draw lessons from particular places that operate with unusually low levels of negotiated guilty pleas, ${ }^{23}$ we can also learn much from concentrating on time periods when guilty plea rates decline. Special attention to periods of declining rates might better explain the causes of, and predict the future of, guilty plea rates. The federal system has seen both-times of boom and bust-in guilty pleas.

If periods of increasing guilty pleas provoke questions about the quality of criminal justice, what answers have we found so far? What qualifies as a rate that is "too high"? The last section of this Part surveys the misleading answers we give from analysis at the individual case level, and the truthful but paralyzing answers we give at the societal level.

\section{A. Federal Guilty Plea Growth Spurts}

The federal courts handled federal crimes from the nation's earliest years, but the number of criminal cases moving through the system each year remained quite small for several decades. Nationwide statistics about federal criminal enforcement first became available in a convenient form in 1871, after Congress required an annual report from the Attorney General. ${ }^{24}$ These reports collected figures for convictions, acquittals, dismissals, and jury trials, but in a telling omission,

There were also some remarkable stretches of stability for the rates in Connecticut. Milton Heumann's study of the superior courts in Connecticut was one of the few efforts to track plea rates over many decades in the twentieth century. Milton Heumann, A Note on Plea Bargaining and Case Pressure, 9 LAW \& Soc'Y REV. 515 (1975). The study confirmed stable trial rates from 1880 to 1954 . See id. at 520. Heumann constructed this study as part of an effort to show that caseload does not drive guilty plea practices; he compared guilty plea rates in high-volume courts to those in low-volume courts, and compared guilty plea rates before and after a large decrease in court caseload (although he did not account for increased system resources to handle the additional cases). See id. at 518-524.

${ }^{23}$ See generally Teresa White Carns \& John Kruse, A Re-evaluation of Alaska's Plea Bargaining Ban, 8 ALASKA L. REV. 27 (1991) (examining the continuing feasibility of Alaska's ban on plea bargaining); Colin Loftin et al., Mandatory Sentencing and Firearms Violence: Evaluating an Alternative to Gun Control, 17 LAW \& SOC’Y REV. 287 (1983) (analyzing Detroit's prosecutorial ban on plea bargaining in firearms cases); Schulhofer, supra note 10 (studying the exceptionally low guilty plea rates in Philadelphia); Ronald Wright \& Marc Miller, The Screening/Bargaining Tradeoff, 55 STAN. L. REV. 29 (2002) (studying the effects of limits on charge bargains and sentence bargains in New Orleans from the 1970s through the 1990s).

${ }^{24}$ See Act of June 22, 1870, ch. 150, § 12, 16 Stat. 162, 164 (requiring the Attorney General to make an annual report including statistics on federal and state crimes), amended by Act of Mar. 3, 1873, ch. 238, § 1, 17 Stat. 578, 578. 
they did not include information about guilty pleas until the 1908 report. ${ }^{25}$

The reports depicted a growing system, although the expansion was uneven, as Table 1 shows. ${ }^{26}$ The earliest annual reports, from the decade of the $1870 \mathrm{~s}$, reported an average of 6,984 cases terminated in the federal criminal docket each year. During the 1920s and early 1930s, spurred by liquor prosecutions under the National Prohibition Act,${ }^{27}$ the number of cases shot up from 26,476 in 1920 to 95,820 in 1932 , before dropping back to 38,667 in $1934,{ }^{28}$ the year after the constitutional basis for the Act was repealed. ${ }^{29}$

Table 1: Average Annual Number of Defendants or Cases, Terminated in Federal Courts by Decades, 1871-2002 ${ }^{30}$

\begin{tabular}{lr}
\hline \hline $1871-1879$ & 6,984 \\
\hline $1880-1889$ & 9,181 \\
\hline $1890-1899$ & 14,026 \\
\hline $1900-1909$ & 8,713 \\
\hline $1910-1919$ & 14,334 \\
\hline $1920-1929$ & 58,326 \\
\hline $1930-1939$ & 64,489 \\
\hline
\end{tabular}

\begin{tabular}{ll}
\hline \hline $1940-1949$ & 41,178 \\
\hline $1950-1959$ & 37,366 \\
\hline $1960-1969$ & 32,782 \\
\hline $1970-1979$ & 46,619 \\
\hline $1980-1989$ & 46,202 \\
\hline $1990-1999$ & 61,364 \\
\hline $2000-2002$ & 76,519 \\
\hline
\end{tabular}

${ }^{25}$ See Finkelstein, supra note 14, at 301 ("Federal data for [guilty plea rates] are available in the Annual Reports of the Attorney General back to 1908." (footnote omitted)). By 1940, the job of collecting and reporting the annual statistics on terminated criminal cases in the federal courts fell to the newly formed Administrative Office of the United States Courts (AOUSC). See Act of Aug. 7, 1939, ch. 501, sec. 1, § 304, 53 Stat. 1223, 1223-24 (establishing the AOUSC and giving that office the duty to collect statistical data of the business transacted by the courts).

${ }^{26}$ See also Edward Rubin, A Statistical Study of Federal Criminal Prosecutions, 1 LAW \& CONTEMP. PROBS. 494, 496-508 (1934) (analyzing criminal prosecutions from 1922 until 1933). For more complete annual statistics, see the Statistical Appendix, supra note 13. Earlier compilations of federal criminal case disposition statistics appear in Finkelstein, supra note 14, apps. I, II, \& III, and ALI, A STUDY OF THE BUSINESS OF THE FEDERAL COURTS, pt. I, at 56-58 (1934).

${ }^{27}$ Pub. L. No. 66-66, 41 Stat. 305 (1919) (repealed 1933) (restricting the use and manufacture of alcoholic beverages).

${ }^{28}$ See Statistical Appendix, supra note 13, at app. 1 (showing the number of convictions, acquittals, and dismissals for each year).

${ }^{29}$ See United States v. Chambers, 291 U.S. 217, 222-26 (1934) (holding that the National Prohibition Act was inoperative following the ratification of the Twenty-First Amendment of the U.S. Constitution and that any prosecutions or appeals pending under that Act were to be dismissed for lack of jurisdiction).

${ }^{30}$ The figures from 1906, 1909, 1935, and 1942-1944 are not included in these averages because the source data is either incorrect, unavailable, or in a different format. See Statistical Appendix, supra note 13, at 4. 
The number of defendants ${ }^{31}$ dropped modestly in the late $1940 \mathrm{~s}$ and $1950 \mathrm{~s}$, partly a result of a decline in immigration cases. ${ }^{32}$ The number surged between 1970 and 1977 and then fell back temporarily from 1977 to 1980. Finally, the system grew in almost every year from 1980 to the present. ${ }^{33}$

Not surprisingly, the number of guilty pleas entered in federal court grew along with the system, but the overall proportion of guilty pleas also ballooned over the last twenty-five years. Using a baseline of all adjudicated cases, ${ }^{34}$ guilty pleas trended downward from the $1950 \mathrm{~s}$ through the 1970 s before starting a sustained climb in 1980 . The vertical line on Figure 1 marks the two distinct periods. ${ }^{35}$ By 2002, defendants pleading guilty represented the largest share of adjudicated cases in the history of federal criminal justice, at $95.2 \% .^{36}$

${ }^{31}$ Starting in 1936, the federal statistics calculate the number of defendants rather than the number of cases. See ALI, supra note 26, at 27 (arguing that the difference between the two units of analysis is not very large in the federal system).

${ }^{32}$ Cf. Statistical Appendix, supra note 13, at 13-14.

${ }^{33}$ See id. at app. 1. Some of this growth is to be expected in a nation with a growing population. In 1950, the federal courts terminated one criminal case for every 3,580 people in the country; in 2000 , the federal courts terminated one criminal case for every 4,760 people.

${ }^{34}$ For a discussion of the merits of adjudicated cases (guilty and nolo pleas, trial convictions, acquittals, and mistrials) as a base, and an alternative base of terminated cases (adjudicated cases plus dismissals), see the Statistical Appendix, supra note 13, at $4-5$.

${ }^{35}$ The story from earlier years is interesting in its own right, but less pertinent for our immediate purposes. The first prominent event in the story of guilty plea rates is the remarkable growth between 1910 (with a starting point of 67.1\%) and 1933 (when the rate reached $91.1 \%$ ). A second phase, from 1935 to 1951, saw a brief drop to $80.4 \%$ in 1941 , and then a decade of increases, topping out at $90.3 \%$ in 1951 . See Statistical Appendix, supra note 13, at app. 1.

${ }^{36}$ That same year guilty pleas accounted for $96.2 \%$ of the federal convictions. See Statistical Appendix, supra note 13, at app. 1 (showing 68,188 guilty pleas and 70,882 convictions in 2002). Reports from the Bureau of Justice Statistics have noted the increased guilty plea rate in recent decades. See, e.g., BUREAU Of Justice STATISTICS, U.S. DeP’T OF Justice, NCJ 197104, Federal Criminal Case Processing, 2001: With TRENDS 1982-2001, at 1 (2003), available at http://www.ojp.usdoj.gov/bjs/pub/pdf/ fccp01.pdf ("Almost all (95\%) of those convicted in [2001 federal criminal cases] pleaded guilty or no contest."). 


\section{Figure 1: Federal Guilty and Nolo Pleas in Adjudicated Cases, 1945-2002 (Percent)}

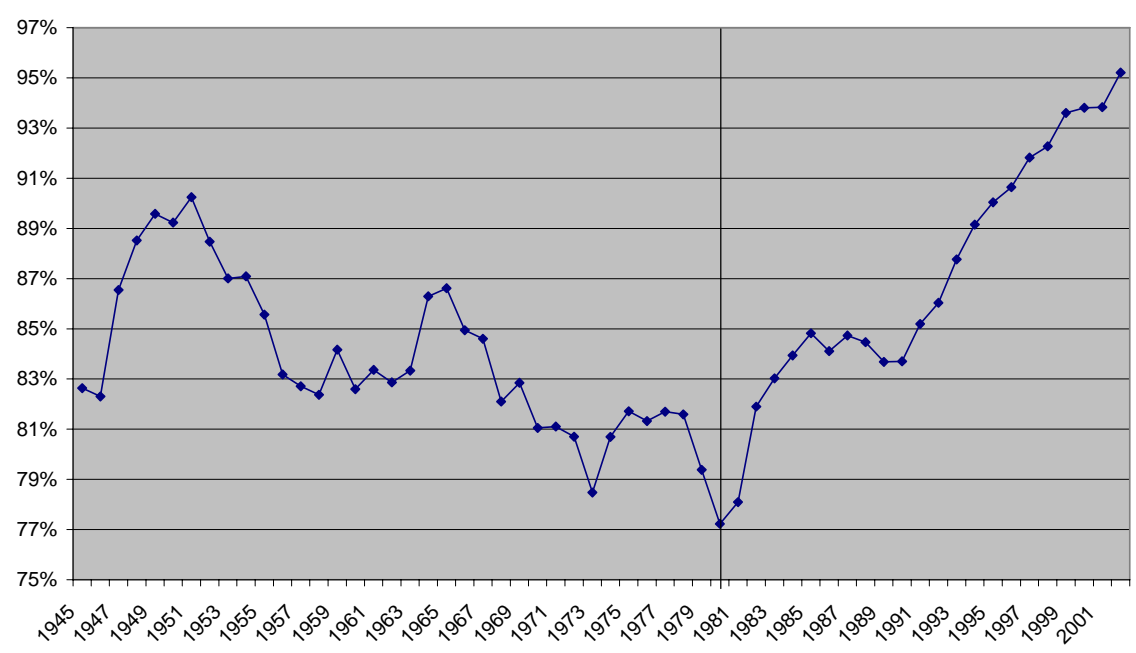

These levels of change in the last quarter of the century carry serious consequences. If plea rates were to fall back to 1980 levels and the total number of defendants remained the same, the number of federal trials (and all the resources needed to support them) would increase nearly ten-fold. ${ }^{37}$

The possible explanations for these high and low tides of guilty pleas must wait for Part III. Before seeking out the causes of the changes, we must become acquainted with two ways to evaluate the growth of guilty pleas.

\section{B. Plea Bargain Theories, Looking High and Low}

In an adversarial system of litigation, can true justice happen in the absence of trials? ${ }^{38}$ There was a time in the United States when judges in criminal cases answered this question with a clear-cut "no."

${ }^{37}$ See Warren Burger, The State of the Judiciary-1970, 56 A.B.A. J. 929, 931 (1970) (noting that a small reduction in guilty pleas could have a large impact on the court system).

${ }^{38}$ Cf. Owen M. Fiss, Against Settlement, 93 YALE L.J. 1073, 1075 (1984) (arguing that settlement poses serious problems for justice and should not be accepted as an alternative to trial); Gillian K. Hadfield, Where Have All the Trials Gone? Settlements, Nontrial Adjudications and Statistical Artifacts in the Changing Disposition of Federal Civil Cases, $1 \mathrm{~J}$. EMPIRICAL LEGAL STUD. 705, 733 (2004) (suggesting that normative evaluation of the disappearance of civil trials depends on whether such trials are replaced by private settlements or public, non-trial adjudication). 
Some judicial opinions from the nineteenth century refused to countenance negotiated guilty pleas, and some even had qualms about guilty pleas entered without apparent negotiations between the prosecution and defense. ${ }^{39}$

And yet the answer to this question today, for those who work daily in courtrooms across the United States, is a troubled "yes." Criminal justice experts-prosecutors, judges, and defense attorneys-assure us that plea bargains are necessary and create important public benefits, ${ }^{40}$ so the practice remains unpopular but stable. The guilty plea rates are sky-high everywhere and have stayed high for decades, yet the sky never falls.

Scholars have created theoretical accounts of guilty pleas on two different levels in response to this reality. Some guilty plea theories evaluate plea negotiations on the micro-level, asking about the intentions of the parties in each case. Other theories pursue a macro-level approach, tracing the broad social effects of discounted sentences. This section will explain why neither level of analysis can help us diagnose problems with and improve plea practices.

\section{Micro-Level Intentions}

One of the important differences among guilty plea theories is the type of information they use for evaluation. Some accounts of guilty pleas look to the intentions of individual actors in each case. These tests fail, however, because they turn on information that is not routinely available.

The standard legal test for the validity of guilty pleas rests on a micro-level inquiry, asking whether the defendant in a particular case "knowingly and voluntarily" waived the right to trial. ${ }^{41}$ Courts and

\footnotetext{
${ }^{39}$ See Edwards v. People, 39 Mich. 760, 763 (1878) (requiring the trial judge to examine the defendant, out of the presence of the prosecutor, about his reasons for pleading guilty, to prevent abuses of prosecutorial power); Commonwealth v. Battis, 1 Mass. 95, 95-96 (1804) (demanding extreme caution in the acceptance of guilty pleas entered in capital cases).

${ }^{40}$ See Barnett E. Hoffman, Letter to the Editor, Courts Would Stall Without Plea Bargains, Home News TriB. (East Brunswick, N.J.), Jan. 9, 2004, at A10 (arguing that, given the extremely high ratio of indictments to judges, plea bargaining is a practical necessity).

${ }^{41}$ See, e.g., United States v. Ruiz, 536 U.S. 622, 629 (2002) (“[T]he Constitution insists ... that the defendant enter a guilty plea that is 'voluntary' and that the defendant must make related waivers 'knowing[ly], intelligent[ly], [and] with sufficient awareness of the relevant circumstances and likely consequences." (brackets in original) (quoting Brady v. United States, 397 U.S. 742, 748 (1970))). See generally MARC L. Miller \& Ronald F. Wright, Criminal Procedures: Cases, Statutes, and Execu-
} 
procedural rules set up easily achieved requirements for demonstrating knowledge: the defendant must know some specifics about the charges filed, the most important procedural rights available at trial, and at least some of the consequences of a conviction. ${ }^{42}$ The defendant in a serious case must also have competent legal counsel to explain this information before pleading guilty. ${ }^{43}$ But when it comes to the defendant's "voluntariness"-the second half of the formulacourts have walked away. The proper knowledge, together with a pro forma statement from the defendant that her guilty plea was not coerced, normally suffices.

Consider some of the coercive environments that are said to produce "voluntary" guilty pleas according to this standard. The size of the differential between the post-trial sentence and the post-plea sentence can become enormous. When a defendant faces a possible life sentence after conviction at trial and the prosecutor offers to reduce charges, making possible a sentence of only a few years, the resulting guilty plea is considered voluntary so long as the defendant says the magic words at the guilty plea hearing. ${ }^{44}$ The strength of the defendant's available defense does not figure at all. The government's evidence gets only the most perfunctory testing when the prosecutor

TIVE MATERIALS 1037-58 (2d ed. 2003) (discussing knowledge, voluntariness, and an adequate factual basis to support the charges as the "three essential ingredients for a valid plea of guilty").

${ }^{42}$ See FED. R. CRIM. P. 11(b) (directing courts, before accepting a guilty plea, to ensure that the defendant understands the rights she waives, that the plea was entered into voluntarily, and that there is a factual basis for the plea); Henderson v. Morgan, 426 U.S. 637, 645 (1976) (holding that a guilty plea is not voluntary unless the defendant receives "real notice of the true nature of the charge against him" (citation and internal quotation marks omitted)); Boykin v. Alabama, 395 U.S. 238, 243 (1969) (requiring that a defendant entering a guilty plea understand that she waives her right against compulsory self-incrimination, her right to trial by jury, and her right to confront her accusers); State v. Bellamy, 835 A.2d 1231, 1238-39 (N.J. 2003) (concluding that, before accepting a defendant's plea, a court must ensure that the defendant understands the possibility of indefinite future civil commitment under the Sexually Violent Predator Act that may result from the plea). But cf. Ruiz, 536 U.S. at 629-33 (allowing the entry of a guilty plea despite the plea agreement's limitations on prosecutorial disclosure of "material impeachment evidence").

${ }^{43}$ See Moore v. Michigan, 355 U.S. 155, 161 (1957) (holding that a defendant in a murder case had a constitutional right to counsel before entering a guilty plea).

${ }^{44}$ For an account of an exceptional case in which the trial judge did not accept a plea of guilty despite the proper catechism responses from the defendant, see Associated Press, Judge Nixes Guilty Plea in AOL Spam Case, Dec. 21, 2004, http://i.abcnews. com/Business/wireStory?id=350717 (reporting that Judge Alvin Hellerstein refused to accept a guilty plea from AOL software engineer Jason Smathers because the judge was not convinced that Smathers had committed a crime under the new federal "canspam" legislation). 
orally summarizes, in a few moments at the guilty plea hearing, the "factual basis" of the government's case. ${ }^{45}$

A defendant can enter a "voluntary" plea even while maintaining her innocence; such Alford pleas are said to express the defendant's voluntary acknowledgement that the government's evidence is too strong. ${ }^{46}$ Even if the judge who will preside at trial and pronounce the sentence urges the defendant to accept a plea offer rather than going to trial, in many jurisdictions such a guilty plea is considered voluntary. ${ }^{47}$

This legal doctrine grows out of a contractual view of plea bargaining. In their purest form, contractual theories evaluate plea negotiations on the same grounds used to evaluate private contract negotiations. For each case, individual negotiators are presumed to act in their own best interests. The presumption is strong, and perhaps irrebuttable: only the parties know their own interests and any systemwide effort to second-guess the outcomes negotiated by willing buyers and sellers would be folly. ${ }^{48}$

These theories treat the potential results at trial as an imperfect measure of what really happened at the scene of the crime; the negotiating parties themselves will have more complete information on this score, without interference from rules of evidence and other artifacts

${ }^{45}$ See FED. R. CRIM. P. 11 (b) (3) (requiring the court to find some factual basis for the plea). The guilty plea can be declared knowing and voluntary even if the judge accepts the guilty plea but does not accept the plea agreement that induced the defendant to plead guilty. See United States v. Hyde, 520 U.S. 670, 671 (1997) (holding that a defendant could not withdraw his plea after the district court had accepted the plea but deferred the decision on whether to accept the plea agreement); Julian A. Cook, III, All Aboard! The Supreme Court, Guilty Pleas, and the Railroading of Criminal Defendants, 75 U. COLO. L. REV. 863, 863-68 (2004) (examining the rules allowing for the acceptance of a guilty plea without acceptance of the plea agreement).

${ }^{46}$ See North Carolina v. Alford, 400 U.S. 25, 37-38 (1970) (holding that a guilty plea could be entered despite the defendant's belief in his innocence when the State demonstrated a strong factual basis for the plea).

${ }^{47}$ See MonT. CODE ANN. \$ 46-12-211 (2005) (allowing the court to advise the defendant regarding whether it will accept a proposed guilty plea and to afford the defendant an opportunity to withdraw that plea); N.C. GEN. STAT. § 15A-1021(a) (2005) (allowing the trial judge to participate in plea discussions); ILL. SUP. CT. R. 402(d) (permitting the trial judge to opine when parties propose a plea deal); State v. Warner, 762 So. 2d 507, 514 (Fla. 2000) (finding that a court may comment on a plea deal proposed by the parties). Only explicit browbeating from the trial judge will lead to a finding that a "knowing" plea was nevertheless "involuntary." See, e.g., State v. Bouie, 817 So. 2d 48, 54-55 (La. 2002) (finding a plea to be involuntary when entered only after repeated statements by the trial judge that acquittal was unlikely and that the sentence differential between a plea and a trial would be at least twenty years).

${ }^{48}$ See Easterbrook, supra note 9, at 308-322 (discussing the desirability of plea bargaining from a market perspective). 
of courtroom proof. ${ }^{49}$ Thus, the match between potential trial results and actual negotiation results is not relevant to the quality of the guilty plea. ${ }^{50}$

Variations on the case-level contractual view of plea bargains-we might label them "motive" theories-focus on the personal motives of prosecutors. They attempt to identify recurring biases in the decisions of prosecutors about whether to accept a proposed plea bargain.

Too often, however, motive theories produce contradictory accounts. One might theorize, based on an economic model of rational behavior, that prosecutors try too few cases because they would rather spend time golfing or pursuing some other leisure. ${ }^{51}$ Or one might argue that prosecutors try too many cases because they want to develop their trial skills and make themselves more attractive to private firms offering large salaries. ${ }^{52}$ These theories are indeterminate because the

49 See Frank H. Easterbrook, Plea Bargaining as Compromise, 101 YALE L.J. 1969, 1970-71 (1992) (arguing that negotiations between sophisticated persons unencumbered by the rules of evidence produces more accurate results than trials produce).

${ }^{50}$ Contractual theories also take more nuanced forms. Robert Scott and William Stuntz concede the defendant's voluntariness for most cases, but identify some exceptional settings where a fully informed (and innocent) defendant might enter an involuntary guilty plea. See Robert E. Scott \& William J. Stuntz, Plea Bargaining as Contract, 101 YALE L.J. 1909, 1957-66 (1992) (examining the problem of incompetent defense lawyering and situations where great disparity exists between a post-trial sentence and a plea sentence). The Scott-Stuntz approach shares some features with trial distortion theory. Like trial distortion theory, Scott and Stuntz measure the legitimacy of plea bargains by their ability to produce accurate convictions. However, they promote rules that make it easier for prosecutors to offer large discounts to defendants in weaker cases and reject efforts to evaluate plea bargains based on the outcomes they produce.

${ }^{51}$ Cf. Stephen J. Schulhofer, Criminal Justice Discretion as a Regulatory System, $17 \mathrm{~J}$. LEGAL STUD. 43, 50-51 (1988) (noting that prosecutors are influenced by day-to-day motivations that may rank higher than maximizing deterrence). Similarly, one might theorize on the basis of sociological insights about "working groups" that prosecutors try too few cases because they put too great a value on stable and non-adversarial relationships with judges and defense attorneys. See, e.g., JAMES EISENSTEIN \& HERBERT JACOB, FELONY JUSTICE: AN ORGANIZATIONAL ANALYSIS OF CRIMINAL COURTS 27-28, 3234 (1977) (describing how working-group dynamics strive to maintain cohesion and reduce conflict within the courtroom); HENRY R. GLICK, COURTS, POLITICS, AND JUSTICE 234 (3d ed. 1993) (positing that close interactions within courtroom working groups encourage plea bargain settlements).

${ }^{52}$ See Edward L. Glaeser et al., What Do Prosecutors Maximize? An Analysis of the Federalization of Drug Crimes, 2 AM. L. \& ECON. REv. 259, 288 (2000) (arguing that the decision to take cases to trial in the federal system is based partly on the desire of prosecutors to develop human capital in trials); Richard T. Boylan \& Cheryl X. Long, Abstract, The Sources of Agency: An Empirical Examination of United States Attorneys (1999), available at http://papers.ssrn.com/abstract=200508 ("[P] rosecutors may take cases to trial to acquire human capital unless they are closely monitored.”).

As a matter of game theory, it is possible that prosecutors would go to trial more often in their weakest cases, but a shift in a few working assumptions leads to the oppo- 
incentives at work on prosecutors and other actors in individual cases point in different directions. The motive theories also concentrate on a secondary level of social problems by promoting efficiency rather than accuracy in criminal justice. The most compelling reason to try more criminal cases is not to encourage an honest day's work from public servants. It is to promote the central reason behind the criminal trial: to sort the innocent from the guilty. ${ }^{53}$

We need an alternative theory of guilty pleas, one that transcends the hidden intentions and grudgingly spoken words of defendants and the contradictory incentives at work on prosecutors in particular cases. An external evaluation of guilty pleas is necessary because none of the negotiating parties will reliably protect the public interest. The prosecutor, as an agent of the public, will not necessarily follow the wishes of the principal. Defense lawyers might also be viewed as agents of the public, assigned the duty of assuring accurate and accountable adjudications of crime. But lack of funding and other obstacles may lead defense attorneys to fall short in these public duties. ${ }^{54}$

site result: prosecutors will go to trial in their strongest cases. See Scott Baker \& Claudio Mezzetti, Prosecutorial Resources, Plea Bargaining, and the Decision To Go to Trial, 17 J.L. ECON. \& ORG. 149, 162-66 (2001) (concluding that prosecutors will only go to trial when they think they have a strong chance of success); Gene M. Grossman \& Michael L. Katz, Plea Bargaining and Social Welfare, 73 AM. ECON. REV. 749 (1983) (describing the motivation of prosecutors to go to trial only where a guilty outcome is appropriate); Jennifer F. Reinganum, Plea Bargaining and Prosecutorial Discretion, 78 AM. ECON. REV. 713, 713-28 (1988) (discussing the strength of a prosecutor's case as a key element in the decision to offer a plea bargain).

${ }^{53}$ See AkHil Reed Amar, The Constitution and Criminal Procedure: First PRINCIPLES 154-55 (1997) (positing a truth-finding function as a central constitutional value of criminal procedure); WiLliam Pizzi, TRIALS Without TRUTH: Why OUR SyStem of Criminal Trials Has Become an EXPENSIVE FaIluRe and WHAT We NeEd TO Do TO REBUILD IT passim (1999) (criticizing U.S. criminal procedure for placing insufficient value on the trial's truth-finding function); Christopher A. Bracey, Book Review, Truth and Legitimacy in the American Criminal Process, 90 J. CRIM. L. \& CRIMINOLOGY 691, 698-99 (2000) (arguing that the truth-finding capacity of police, prosecutors, and courts is central to the public legitimacy of criminal justice).

${ }^{54}$ See AM. Bar Ass'N Standing Comm. ON Legal Aid \& Indigent Defendants, GIDEON's BROKEN PROMISE: AMERICA's CONTINUING QUEST FOR EQUAL JUSTICE 7-13 (2004), available at http:/ /www.abanet.org/legalservices/sclaid/defender/brokenpromise/ fullreport.pdf (finding that many defendants are represented by lawyers who are without adequate resources to provide effective representation); Albert W. Alschuler, The Defense Attorney's Role in Plea Bargaining, 84 YALE L.J. 1179, 1206-55 (1975) (discussing the limits and the pressures put upon public defenders in plea bargaining); Ronald $\mathrm{F}$. Wright, Parity of Resources for Defense Counsel and the Reach of Public Choice Theory, 90 IowA L. REV. 219, 221-25 (2004) (discussing the relative lack of resources provided to public defenders and potential sources for remedy). 
Thus, there are public interests at stake in plea negotiations that both parties at the table might ignore. ${ }^{55}$ The public's interests in plea discounts of the right scope can be protected best in a process that is open to public scrutiny and accountability. ${ }^{56}$ Outsiders must be able to estimate, based on the likely views of judges and juries who evaluate admissible evidence, what would have occurred at trial and use that estimate to test the predictions or calculations of the parties.

It may be impractical to make such judgments in individual cases, for that would require access to all the witnesses and evidence that might play out at trial. But the insistence that the parties do not always know best-central to a trial distortion theory-gets stronger when observers review outcomes in many cases across time. ${ }^{57}$ Patterns in outcomes can signal potentially distorting plea negotiation practices, even if the reliability of evidence from case to case is unknowable. Whatever the words that defendants utter at the plea hearings, a system should not tolerate plea bargaining practices that distort the outcomes that would have occurred at trial.

\section{Macro-Level Social Purposes}

Other approaches to guilty pleas move outside the minds of the negotiating parties-and outside the criminal courtroom altogetherto ask whether guilty pleas serve larger social purposes. Some writers in this vein conclude that they do, while others judge plea bargains a failure and call for their abolition. Despite their disparate vantage points, these perspectives on plea bargaining share common ground: they discuss plea bargaining as a social institution that must stand or fall as a whole.

Crime control plays a leading role among the relevant social purposes that plea bargaining can serve. Under this approach, plea negotiations succeed if they extend the power of government to punish

${ }^{55}$ See Stephen J. Schulhofer, Plea Bargaining as Disaster, 101 YALE L.J. 1979, 1985-90 (1992) (arguing that both prosecutors and defenders may fail to internalize serious issues of public interest in their plea negotiations); Easterbrook, supra note 49, at 1970 (noting that prosecutors and defense attorneys often agree to plea negotiations because they believe all defendants are guilty).

${ }^{56}$ See Ronald Wright \& Marc Miller, Honesty and Opacity in Charge Bargains, 55 STAN. L. REV. 1409, 1410-12 (2003) (arguing in favor of greater transparency in plea bargaining).

${ }_{57}$ For an influential exploration of the conditions that make the parties less than trustworthy in evaluating plea bargains, see Bibas, supra note 12, at 2470-82 (discussing the troublesome incentives of prosecutors and defense attorneys entering plea negotiations). 
(and therefore to control) crime. ${ }^{58}$ Economic models of plea bargaining urge prosecutors to obtain as much criminal punishment as possible within a limited office budget. ${ }^{59}$ Social cohesion is another public purpose used to evaluate guilty pleas. Some social historians posit that plea bargaining allows elite social classes to soften the enforcement of a criminal law that falls heavily on the lower social orders, and that it thereby reduces social conflict. ${ }^{60}$

Legal scholars who criticize plea bargains answer these claims on several levels. First, they dispute the factual claims about the degree of crime control or social cohesion believed to flow from plea bargains. ${ }^{61}$ And on a normative level, abolitionists give central impor-

${ }^{58}$ Cf. Gary S. Becker, Crime and Punishment: An Economic Approach, 76 J. PoL. ECON. 169, 176-79 (1968) (arguing that criminal law procedures that increase conviction rates make crime less economically beneficial, thereby reducing the incentive to engage in criminal offenses); Easterbrook, supra note 9, at 289 (arguing that plea bargaining is one of several elements of the criminal justice system that set the "price" of crime); Fred C. Zacharias, Justice in Plea Bargaining, 39 WM. \& MARY L. REV. 1121, 113549 (1998) (discussing the taxonomy of just results theories and resource/efficiency theories). In Zacharias's scheme, trial distortion theory would be considered a "just results" theory. See id. at 1135-44 (describing the premises and justifications of "just results" theories).

${ }^{59}$ See William Landes, An Economic Analysis of the Courts, 14 J.L. \& ECON. 61, 63-64 (1971) (noting that prosecutors must work within their offices' budgetary constraints to maximize the number of convictions and their resulting sentences); Jennifer F. Reinganum, Sentencing Guidelines, Judicial Discretion and Plea Bargaining, 31 RAND J. ECON. 62, 69 (2000) (treating a prosecutor's objective as maximizing prison sentences while minimizing the cost of prosecution). Prosecutors themselves care more about accuracy and less about maximum coverage than economic theory suggests. See DAVID T. Johnson, The Japanese Way OF Justice: ProseCuting Crime in JAPAN 97-98 \& tbl.3.1 (2002) (describing survey responses of American and Japanese prosecutors); Brian Forst \& Kathleen B. Brosi, A Theoretical and Empirical Analysis of the Prosecutor, 6 J. LEG. STUD. 177, 178-79 (1977) (arguing that prosecutors, to obtain greater crime-rate reductions, choose to focus their resources on cases involving recidivists rather than on those involving first-time offenders); $c f$. Alissa Pollitz Worden, Policymaking by Prosecutors: The Uses of Discretion in Regulating Plea Bargaining, 73 JUDICATURE 335, 340 (1990) (concluding from statistical data that prosecutors are more concerned with ensuring due process than maximizing conviction rates).

${ }^{60}$ See Mary E. Vogel, The Social Origins of Plea Bargaining: Conflict and the Law in the Process of State Formation, 1830-1860, 33 LAW \& SOC'Y REV. 161, 235-37 (1999) (arguing that plea bargaining was developed in part as an effort by the courts to include members of the lower social orders in the political system and to thus give them a better opportunity for citizenship). For persuasive critiques of Vogel's account, see FISHER, supra note 22, at 11 (arguing that plea bargaining should be understood as a legal, not social, phenomenon); Stephanos Bibas, Pleas' Progress, 102 MicH. L. REV. 1024, 1030 (2004) (reviewing FISHER, supra note 22).

${ }^{61}$ See Albert W. Alschuler, Implementing the Criminal Defendant's Right to Trial: Alternatives to the Plea Bargaining System, 50 U. CHI. L. REV. 931, 940 (1983) (citing the reduced duration of felony cases following the imposition of Alaska's ban on plea bargaining as evidence that the practice does not save resources); Schulhofer, supra note 
tance to lawyerly process values: even weighty social ends do not justify sordid procedural means. ${ }^{62}$ In utilitarian terms, it is corrosive to ignore the question of public confidence in the quality of criminal case outcomes.

Both the positive social purpose theories and the abolitionist critiques analyze plea bargains at a high level of abstraction. The theories address plea bargaining as a social institution, with similar effects for good or for ill wherever it goes. Discussion at the macro level, however, has proven useless in viable legal reform efforts, for its all-ornothing reform agenda is dispiriting in a world where plea bargaining is so entrenched. ${ }^{63}$ Instead, we need a mid-level theory-something between the accounts focused on the individual-case level and the social-institution level-that evaluates plea bargaining as an artifact of a particular criminal justice system, with different features from place to place.

A mid-level theory would offer two sorts of advantages over the micro- and social-level accounts of plea bargaining. First, as an administrative matter, the social-purpose theories rely on evidence that is difficult to obtain. To evaluate guilty pleas under a social-purpose theory, we must estimate whether a society might experience more crime or more social conflict if the law discouraged or barred certain plea negotiations. Instead, a mid-level theory would direct us to accessible sources when judging the quality of plea negotiation practices. ${ }^{64}$ Such a theory would require us to examine the patterns of procedural outcomes across the system as a whole, rather than the intentions of the parties in particular cases or the larger social ends that guilty pleas might achieve. In short, a mid-level theory would depend on the types of evidence that working criminal justice professionals already routinely collect, and it asks professionals and scholars to make judgments they are competent to make.

55, at 1988 (arguing that any crime-control benefits derived from plea bargaining may be undermined by competing economic pressures on assistant prosecutors).

${ }^{62}$ See Albert W. Alschuler, The Changing Plea Bargaining Debate, 69 CAL. L. REV. 652, 671-77 (1981) (arguing that it is morally impermissible in Kantian terms to balance virtues of trials against economic costs of trials).

${ }^{63}$ See Fisher, supra note 11, at 1067-75 (discussing how plea bargaining has become entrenched despite the existence of alternative mechanisms of criminal case resolution).

${ }^{64}$ George Fisher presents the account of plea bargaining that most closely resembles the mid-level theory I elaborate here. Fisher rejects the social-purpose theories and constructs an historical account of plea bargaining that looks to the evidence available from courtroom practices. See id. at 893-936. 
The second advantage of a mid-level theory is its ability to respond to meaningful differences among types of guilty plea practices. Public attitudes reflect this divided reality, ${ }^{65}$ and fundamentals of human psychology suggest that some plea bargains are worse than others. ${ }^{66}$ We now turn to one possible mid-level indicator of troublesome negotiating practices: the number of acquittals in a jurisdiction.

\section{ACQUITTALS AS A WARNING}

Look around the globe, and you will find criminal justice systems where extremely low rates of acquittals reveal profound trouble. ${ }^{67}$ In the courts of the former Soviet Union, for example, acquittal rates remained extremely low, largely because the judges knew that acquittals threatened their career advancement. ${ }^{68}$ Soviet judges could not afford to take very seriously the truth-finding function of criminal adjudication. On the other hand, remarkably low acquittal rates in other countries inspire more confidence. The Japanese courts acquit

${ }^{65}$ See Sergio Herzog, The Relationship Between Public Perceptions of Crime Seriousness and Support for Plea-Bargaining Practices in Israel: A Factorial-Survey Approach, 94 J. CRIM. L. \& CRIMINOLOGY 103, 127-28 (2003) (finding that public disapproval of plea bargaining is stronger for more serious offenses).

${ }^{66}$ See generally Bibas, supra note 12 (applying a structural-psychological perspective to the analysis of plea bargaining and the influence of party incentives).

${ }^{67}$ The differences in acquittal rates correlate with differences in guilty plea negotiation practices. Today, most countries with a civil law tradition do allow some form of negotiation between the parties in criminal matters, but these countries are still less hospitable to guilty plea negotiations than we are in the United States. See JoHnson, supra note 59, at 246 (noting that guilty pleas are not formally recognized in Japan and that most cases are instead based on "confessions"); Richard S. Frase \& Thomas Weigend, German Criminal Justice as a Guide to American Law Reform: Similar Problems, Better Solutions?, 18 B.C. INT'L \& COMP. L. REV. 317, 344-46 (1995) (noting that while Germany does not explicitly allow plea bargaining, analogues of plea negotiations do take place); Geraldine Szott Moohr, Prosecutorial Power in an Adversarial System: Lessons from Current White Collar Cases and the Inquisitorial Model, 8 BUFF. CRIM. L. REV. 165, 208 (2004) (arguing that a comparison of the roles of American federal prosecutors and their European counterparts in investigating, charging, and sentencing confirms that our present system has "a decidedly administrative cast," giving federal prosecutors all the powers of inquisitorial prosecutors without the formal and informal limits on that power).

${ }^{68}$ See Peter H. Solomon, Jr., The Case of the Vanishing Acquittal: Informal Norms and the Practice of Soviet Criminal Justice, 39 SOVIET STUD. 531, 536-38 (1987) (positing that low acquittal rates from judges in the Soviet Union resulted from pressure from political parties that controlled nomination for judicial reelection and from oversight by superiors). 
very few defendants, yet the review and resources devoted to each case make the system a potentially positive model. ${ }^{69}$

Such divergent lessons about acquittals also play out in the United States. Low acquittal rates in some jurisdictions might reflect a tragic indifference to the truth and the prosecutors' determination above all to secure convictions. Conversely, low acquittal rates might bring positive news of prosecutors who select and prepare cases with great care, defense attorneys who have enough time and resources to develop the best available defense, and sentencing judges who offer only a modest benefit for pleading guilty.

So a significant drop in acquittal rates is an important event in a criminal justice system, but it is ambiguous when it comes to the truthfinding function of the law. Lower acquittal rates should serve only as a warning light, a reason to examine a system more closely for other signs that the environment is compromising reliable outcomes. On this score, the federal system reveals a point of genuine concern, because for the last twenty-five years acquittals have dropped faster than dismissals or trial convictions.

\section{A. Federal Acquittal Rates and the Guilty Plea Connection}

It is no surprise that when guilty plea rates rise, acquittal rates fall, and vice versa. Figure 2 shows the long-term trends for acquittals in the federal system.

\footnotetext{
${ }^{69}$ Acquittals in Japan remain low, perhaps, because the prosecutors have the time and incentive to screen out their weakest cases. See JOHNSON, supra note 59, ch. 7 (arguing that the low acquittal levels in Japan arise in part from the combination of a "conservative charging policy" and the ability of Japanese prosecutors to investigate cases more thoroughly before charging a defendant); J. Mark Ramseyer \& Eric B. Rasmusen, Why Is the Japanese Conviction Rate So High?, 30 J. LEGAL STUD. 53, 53 (2001) ("[T] he high conviction rates [in Japan] reflect case selection and low prosecutorial budgets; understaffed prosecutors present judges with only the most obviously guilty defendants."). But see Hiroshi Matsubara, Trial by Prosecutor, LEgAL AfF., Mar.-Apr. 2003, at 11, 11-12 (arguing that Japan's high conviction rate reflects procedural injustice). For a discussion of acquittal and guilty plea rates in another common law system, see Michael Zander, What the Annual Statistics Tell Us About Pleas and Acquittals, 1991 CRIM. L. REV. 252, 252 (noting that pleas in Great Britain went up in the 1980s from $62 \%$ to $72 \%$ of defendants, but acquittal rates stayed flat).
} 


\section{Figure 2: Federal Acquittals and Mistrials in Adjudicated Cases, 1945-2002 (Percent) ${ }^{70}$}

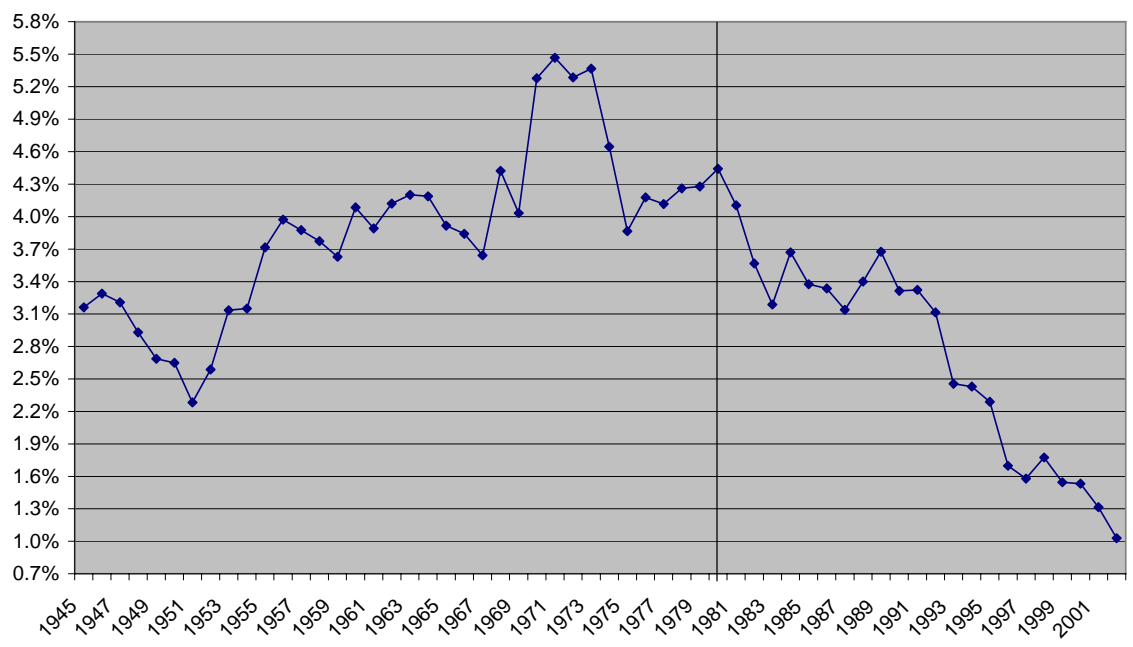

During the two decades from 1951 through 1971, acquittal rates rose to their highest post-World War II levels, up from $2.3 \%$ in 1951 to $5.5 \%$ in 1971 . The years since 1971 brought acquittal rates down to the lowest level in the history of the federal criminal justice system: $1 \%$ in 2002. ${ }^{71}$ The declines since 1989 have been particularly steep.

${ }^{70}$ The statistics supporting this figure, which are compiled in the Statistical Appendix, supra note 13, at app. 1, derive from the AOUSC. See Bureau of Justice Statistics, Federal Justice Statistics Resource Center (2003), http://fjsrc.urban.org/ noframe/download.cfm (follow the "Download Data" hyperlink; then the "Standard Analysis Files" hyperlink; then the hyperlink for the dataset desired; and then apply the recommended compression software to obtain data in a form suitable for processing by statistical management software, such as SPSS or SAS). The AOUSC defines "acquittals" to include acquittals, mistrials, or verdicts of not guilty by reason of insanity. In cases of multiple counts charged against a single defendant in a case, the outcome of the most serious charged offense is used to classify the case. Thus, a defendant who obtains an acquittal on the most serious count and convictions on lesser counts would be classified as an acquittal.

The vertical line on Figure 2 marks the point at which guilty pleas began a sustained climb in 1980. See Figure 1.

${ }^{71}$ Earlier periods also saw interesting interactions between guilty pleas and acquittals. Between 1910 and 1933, as guilty plea rates climbed, the acquittal rates fell more severely than at any other time in the century-from nearly $15 \%$ to $1.9 \%$-continuing a long-term slide from highs of almost $24 \%$ in the 1890s. Between 1934 and 1951, while the guilty plea rates fell and then rose, the acquittal rates rose and then fell. See Statistical Appendix, supra note 13, at app. 1. 
Although the acquittal rates show an intuitive connection with guilty plea rates (acquittal rates go down when guilty plea rates go up), a closer look reveals a more important and subtle feature of the relationship: comparably high guilty plea rates do not always produce equally low acquittal rates. The years 1951 and 2002 produced two of the higher points in guilty plea percentages, with roughly the same rates in both years (at $90.3 \%$ and $95.2 \%$, respectively). Yet those same years did not generate equally low acquittals: The acquittal rate for $1951(2.3 \%)$ was over twice as high as the rate in $2002(1 \%){ }^{72}$ Put in terms of a ratio, guilty pleas outnumbered acquittals 40 to 1 in 1951, and 93 to 1 in 2002, making the imbalance of recent years the most extreme in the history of federal criminal justice.

Even though acquittals tend to go down when guilty pleas go up, it is not true that higher guilty plea rates cause lower acquittal rates. Rather, certain plea negotiation practices cause the changes in both of these dispositions. Those times and places where the ratio between guilty pleas and acquittals reach their highest point deserve the closest scrutiny, for there we find the greatest risk that plea negotiations are distorting the outcomes that would happen at trial.

\section{B. Acquittals and the Other Displaced Outcomes}

So far I have treated acquittal rates and guilty plea rates as a bilateral relationship, when in fact the relationship is multilateral. Guilty plea rates change alongside acquittals, but they also change along with trial convictions, dismissals by judges, and dismissals by prosecutors.

As slices of the disposition pie, acquittals, dismissals, and trial convictions all tend to shrink as the guilty plea slice grows larger, but the amount that each shrinks is not preordained. It is possible that guilty plea negotiations could affect all of the alternatives equally. ${ }^{73}$ But it is

Bench trial acquittal rates increased from 1982 to 2001 across all crime types. See Statistical Appendix, supra note 13, at app. 5; cf. Andrew D. Leipold, Why Are Federal Judges So Acquittal Prone?, 83 WASH. U. L.Q. 151, 164 fig.3, 166 \& fig.5 (2005) (charting the federal bench trial conviction rates since 1946). On the other hand, from 1946 to the early 1960s, judges had higher conviction rates than juries. See Leipold, supra, at 164 fig.3.

${ }^{72}$ See Statistical Appendix, supra note 13, at app. 1.

${ }^{73}$ For instance, imagine that a guilty plea rate of $70 \%$ occurs in Year 1 alongside $20 \%$ dismissals, $7 \%$ trial convictions, and $3 \%$ acquittals. If that guilty plea rate rises to $75 \%$ in Year 2, and simultaneously moves the dismissals down to $16.7 \%$, the trial convictions to $5.8 \%$, and the acquittals to $2.5 \%$, then the growth in guilty pleas reduces each of the alternatives in equal proportions. That is, the mix among the non-plea outcomes remains the same; in both Year 1 and Year 2, acquittals account for $10 \%$ of the non-plea outcomes ( 3 of 30 in Year 1 and 2.5 of 25 in Year 2). 
also possible that guilty pleas could displace acquittals at a faster rate than the other non-plea outcomes, and change the mix over time. As Figures 3 and 4 show, the acquittal slice of the pie in the federal system has been shrinking more quickly than the slices for dismissals or trial convictions. Acquittals now occupy a smaller portion of the nonplea outcomes than at any time since the repeal of Prohibition.

Figure 3 tracks the relationship between acquittals on the one hand and dismissals on the other, expressed as a ratio of dismissals to acquittals. Larger numbers (higher points on the vertical axis) denote a weakening of acquittals compared to dismissals. As the upward movement of the graph shows, acquittals have lost ground to trial convictions and dismissals since the 1950s. Just before the rate of guilty pleas bottomed out in the 1970s, dismissals gained ground on acquittals and the graph line moved up more steeply. The most recent decade brought the highest ratios of dismissals to acquittals.

\section{Figure 3: Ratio of Dismissals to Acquittals in Federal Court, 1950-2002}

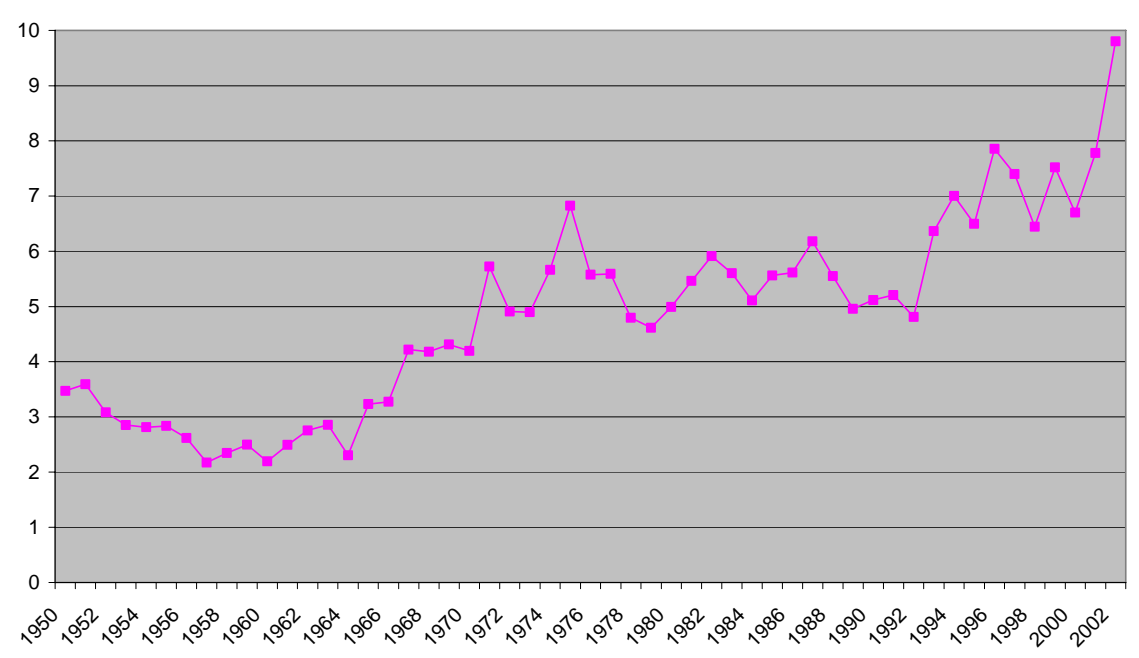




\section{Figure 4: Ratio of Trial Convictions to Acquittals in Federal Court, 1950-2002}

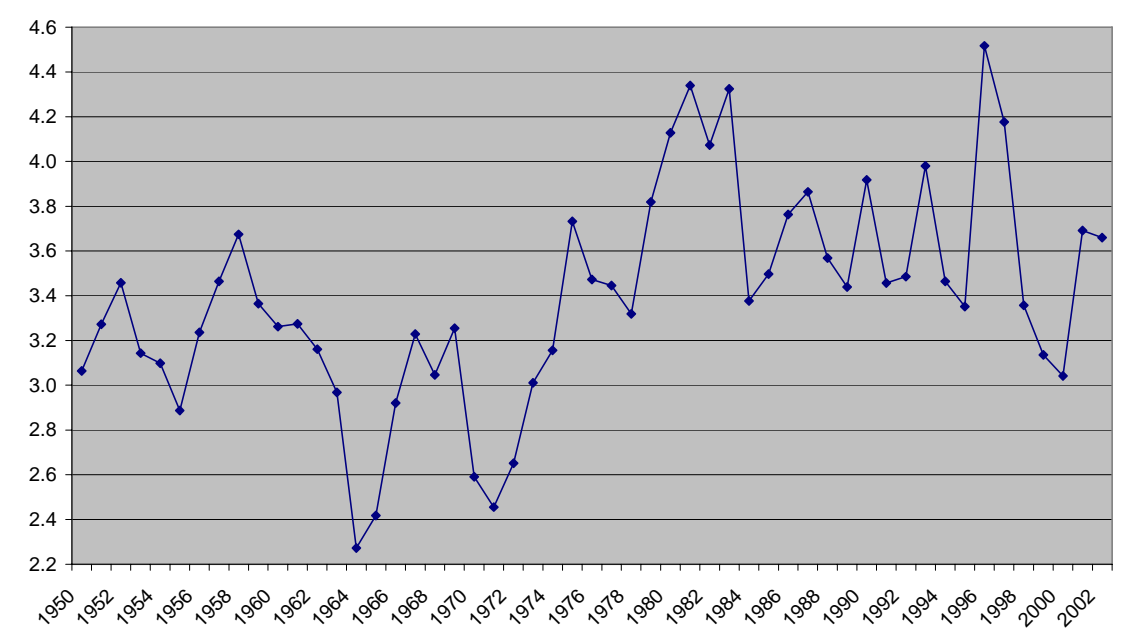

Figure 4 gives us a separate picture of the acquittal-trial conviction relationship. The graph line here also runs in a telling direction. During the 1950 s and 1960 s, when guilty pleas were decreasing, acquittals gained ground on trial convictions. In recent decades, as guilty pleas increased, trial convictions became more common than acquittals and the graph line shifted higher. ${ }^{74}$

${ }^{74}$ Because dismissals and acquittals both result in non-conviction (and freedom) for a defendant, one additional relationship among the outcomes merits attention: the changing ratio of dismissals and acquittals on the one hand to trial convictions on the other. A figure illustrating this relationship over time appears in the Statistical Appendix, supra note 13, at 6 .

The relationship between acquittals and dismissals was the center of attention in Finkelstein's 1975 analysis, supra note 14. He labeled the difference between the average acquittal and dismissal rate and a particular district's acquittal and dismissal rate as the "implicit non-conviction" rate, $i d$. at 295-98, arguing that districts with belowaverage non-conviction rates would likely produce extra acquittals and dismissals if those districts had a lower guilty plea rate. See id. at 304-09. This article was based on an ingenious insight, and tracked federal criminal justice outcomes more thoroughly than any study had done since the American Law Institute study in the 1930s. See ALI, supra note 26 (studying criminal cases in thirteen federal district courts over a period of three years).

While the idea is useful, Finkelstein's analysis remains incomplete for purposes of evaluating plea bargain practices. First, he did not explore in any detail the different possible causes of below-average acquittal and dismissal rates. He used a two-variable regression, tracking correlations between acquittals and guilty pleas without attempting to measure other differences among districts. Second, Finkelstein combined trial convictions and guilty pleas rather than independently tracking their interaction with acquittals and dismissals. This combination obscures the impact of guilty pleas across 
Overall, the increased prevalence of guilty pleas since the $1980 \mathrm{~s}$ spells danger for federal criminal justice. Guilty plea negotiations have crowded out other alternatives, taking the heaviest toll on acquittals.

\section{The Mid-Level Trial Distortion Theory}

Up to this point in the Article, only a quick outline of the trial distortion theory was necessary as background to our review of guilty plea rates and other dispositions in the federal system. More detail is now required, however, as we sort through the possible meanings one might attach to high guilty plea and low acquittal rates.

Trial distortion theory walks a path between the micro- and macro-level accounts of guilty pleas. It differs from micro-level methods of evaluating guilty pleas because it examines patterns across many cases rather than reconstructing evidence and events in particular cases. ${ }^{75}$ It differs from macro-level methods because it remains focused on courtroom results rather than crime control, social cohesion, or other broad-based social effects. This path between the micro- and the macro-levels uses information readily at hand to create a targeted critique of plea practices.

Ideally, under trial distortion theory, extra guilty pleas should produce the same mix of convictions and non-convictions that a system would produce if every filed case either went to trial or was dismissed. ${ }^{76}$ Every person who holds a genuine factual or legal defense to the crime as charged should either be acquitted at trial or leave the system when the prosecutor decides not to file the charge or when the prosecutor or judge dismisses the charge. Because such a person should not be convicted at trial, that defendant likewise should not

all the alternative outcomes. Third, Finkelstein did not use the diagnostic tool he pioneered to find particular plea practices to regulate. Instead, he treated the presence of "implicit non-convictions" as a basis for outright abolition of guilty pleas. Fourth, combining dismissals and acquittals makes it difficult to interpret the meaning of trends. Dismissals, more easily than acquittals, can be taken as a sign of increasing accuracy in a system, for reasons discussed in Part II.C.

${ }^{75}$ A case-level effort to estimate acquittal rates that might exist in the absence of guilty pleas appears in William M. Rhodes, Plea Bargaining: Its Effect on Sentencing and Convictions in the District of Columbia, 70 J. CRIM. L. \& CRIMINOLOGY 360 (1979). Rhodes collected several case-file variables that indicate the strength of evidence in order to estimate the probability of conviction if a defendant pleading guilty had instead gone to trial. Id. at 364 .

${ }^{76}$ In this mental exercise, the imagined trials that the guilty pleas replace take an average length of time based on current trial practices, supported with the personnel and resources available for the typical trial. 
plead guilty, at least from a societal perspective where the system's legitimacy is at stake. ${ }^{77}$

The theory at the bottom of this enterprise treats trial outcomes, by definition, as truthful outcomes. Obviously, trial outcomes do not always accurately reflect the events that occurred at the scene of the crime. $^{78}$ Nevertheless, trial distortion theory relies on the lawyerly assumption, built into the deepest convictions of the adversarial process, that this method of ascertaining the truth is more reliable-on average across a system-than other methods of reconstructing truth after the fact. ${ }^{79}$ In particular, this theory treats the outcome of public proceedings as presumptively more accurate than the outcome of unseen negotiations between the parties. It also reflects the judgment that a prosecutor's choices about which defendants are factually guilty and what range of punishment they deserve should be subject to evaluation by others.

\section{Trial Distortion and Trial Penalties}

Since the earliest public discussions of "compromises" in criminal cases, defenders of plea bargains have argued that the negotiating parties simply replicate the likely outcomes of a trial. ${ }^{80}$ Each party estimates the chances of conviction and the sentence a judge would probably impose after conviction at trial. Then together they settle on the proper amount to compensate the defendant for removing uncertainty about the outcome at trial and for saving the government and

${ }^{77}$ See Givelber, supra note 7, at 1342-44 (discussing the problem of innocent defendants accepting guilty pleas); Andrew D. Leipold, The Problem of the Innocent, Acquitted Defendant, 94 Nw. U. L. REV. 1297, 1354 (2000) (suggesting that the court should not accept a guilty plea from a factually innocent defendant).

${ }^{78}$ For one example of a gap between trial outcomes and truth in the real world, see Fox Butterfield, Guns and Jeers Used by Gangs To Buy Silence, N.Y. Times, Jan. 16, 2005 , at 1 (describing the use of intimidation to prevent gang members from cooperating with the police in drug trials in Boston).

${ }^{79}$ For a comparison of civil- and common-law perspectives on the truth-finding function of the trial, see Mirjan Damaška, Evidentiary Barriers to Conviction and Two Models of Criminal Procedure: A Comparative Study, 121 U. PA. L. REV. 506, 580-87 (1973) ("I contend that the continental non-adversary system of procedure is more committed to the search for truth than is the Anglo-American adversary system.”).

${ }^{80}$ See Justin Miller, The Compromise of Criminal Cases, 1 S. CAL. L. REV. 1, 2-8 (1927) (discussing the various sorts of "compromise" that represent viable alternatives to criminal trial); Moley, supra note 20, at 123 (summarizing the arguments favoring plea bargaining, as stated by prosecutors in the 1920s); S. Chesterfield Oppenheim, Waiver of Trial by Jury in Criminal Cases, 25 MICH. L. REV. 695, 710-17 (1927) (arguing that public interest theory accepts a guilty plea as an appropriate alternative to a trial in a criminal case). 
its witnesses the resources necessary to try the case. In this happy account of rational economic actors, the negotiations for guilty pleas take place "in the shadow of the trial" and merely save system resources. ${ }^{81}$

By invoking this hoary theme in the debates about the legitimacy of plea bargaining, I do not make any descriptive claim. Without a doubt, some bargains do not produce results that resemble what a trial would have produced; not all bargaining happens in the shadow of trials. Perhaps prosecutors have their reasons to grant concessions that are too large; perhaps defense attorneys act as unfaithful agents for their clients and ask for too little. ${ }^{82}$ Defendants themselves might poorly predict the likely outcome of a trial. ${ }^{83}$

Instead, the trial distortion theory is normative: plea practices are good to the extent that they mimic trial results, with proper routine sentence discounts. In this view, not all guilty pleas are created equal and not all forms of coercion used to induce a plea of guilty are equally troubling. The coercive power of strong evidence creates no concern. Some defendants plead guilty simply because they accept responsibility for their crimes or recognize the futility of resisting the government's strong evidence. These easy cases would have produced convictions even without the guilty pleas, but only after trials purchased at greater public expense, so the savings from the plea can be devoted to additional criminal cases or to other social priorities.

${ }^{81}$ For examples of discussions treating plea bargains as taking place in the shadow of trials, see Thomas W. Church, Jr., In Defense of "Bargain Justice," 13 LAW \& SOC'Y REV. 509, 513 (1979) ("Any criminal defendant faces unpleasant alternatives: he can either plead guilty or defend himself at trial."); Susan N. Herman, Applying Apprendi to the Federal Sentencing Guidelines: You Say You Want a Revolution?, 87 IOWA L. REV. 615, 632 (2002) (“[T] he prosecutors' and defense attorneys' estimation of how a jury might decide a case becomes the benchmark against which plea bargaining takes place. . . It is in cases where the two sides have different expectations of a jury ... that a trial will occur.").

${ }^{82}$ See Candace McCoy, Politics and Plea Bargaining: Victims' Rights in CALIFORNIA Xvii (1993) (discussing how politics can cause poor plea bargaining results by reducing the amount of scrutiny given to individual cases); Schulhofer, supra note 55 , at 1987-91 (discussing how, in the reality of plea bargaining, "[t] he real parties in interest (the public and the defendant) are represented by agents (the prosecutor and the defense attorney) whose goals are far from congruent with those of the principals," carrying "a potential for conflicts of interest").

${ }^{83}$ Stephanos Bibas has ably catalogued a variety of reasons-some of them built into the institutional arrangements of the criminal courtroom, others growing out of common human failures to process information rationally- that most plea bargains may not accurately predict trial results. See Bibas, supra note 12, at 2496-527 (analyzing the various ways in which human psychology poses serious pitfalls for plea bargaining). 
Trial-distorting plea bargains are more likely to occur in cases where the government has weak evidence to support the charges as filed. ${ }^{84}$ In these cases, the discount that a prosecutor offers might grow quite large, because a lucrative offer is needed to convince a defendant to give up a strong chance of outright acquittal. The rational prosecutor must set a "market-clearing" price high enough to obtain guilty pleas even in weak cases.

One difficulty with such large plea discounts (or trial penalties) is the effect they might have on defendants. ${ }^{85}$ The difference between the predicted sentence after a trial conviction and the predicted sentence after a guilty plea could become so large that some defendants would not accurately weigh their options and would not dare go to trial, even with a strong defense. ${ }^{86}$

More to the point, these discounts might grow so large in some cases that they become unworthy of public support, regardless of their

${ }^{84}$ See David Lynch, The Impropriety of Plea Agreements: A Tale of Two Counties, 19 LAW \& SOC. INQUIRY 115, 132 (1994) ("[M] any prosecutors . . . will . . . resort to offering incredibly lenient punishments to assure the entry of guilty pleas in those weak cases that probably would and should be lost at trials . . .."); cf. Albert W. Alschuler, The Prosecutor's Role in Plea Bargaining, 36 U. CHI. L. REV. 50, 58-65 (1968) (arguing that prosecutors seek bargains most persistently in their weakest cases to ensure some positive outcome); Dean J. Champion, Private Counsels and Public Defenders: A Look at Weak Cases, Prior Records, and Leniency in Plea Bargaining, 17 J. CRIM. JUST. 253, 261-62 (1989) (finding that, when deciding the terms of a plea agreement, prosecutors took into account not only the strength of the evidence but also who represented the defendant).

${ }^{85}$ See Richard Birke, Reconciling Loss Aversion and Guilty Pleas, 1999 UTAH L. REV. 205, 207-09 (applying prospect theory to plea bargaining and arguing that the most likely reason for the inapplicability of prospect theory is that prosecutors offer such a large guilty plea bonus that it overcomes all other incentives); Hans Zeisl, The Offer That Cannot Be Refused, in FrAnkLin E. ZIMring \& Richard S. Frase, THE Criminal Justice SYSTEM: MATERIALS ON THE ADMINISTRATION AND REFORM OF THE CRIMINAL LAW 558, 559-60 (1980) ("[T] he greater the difference between the offered sentence and the sentence expected after conviction at trial, the more defendants will plead guilty and avoid trial."); Note, Plea Bargaining and the Transformation of the Criminal Process, 90 HARV. L. REV. 564, 574-76 (1977) (positing that fear of a heavier sentence after trial might lead defendants to accept virtually any offered plea bargain).

${ }^{86}$ See Donald G. Gifford, Meaningful Reform of Plea Bargaining: The Control of Prosecutorial Discretion, 1983 U. ILL. L. REV. 37, 45-53 (arguing that most plea bargains are unconscionable because they result from unequal bargaining power and involuntary because defendants do not understand their situation); Daniel Givelber, Punishing Protestations of Innocence: Denying Responsibility and Its Consequences, 37 AM. CRIM. L. REV. 1363, 1394-98 (2000) (noting that sentencing guidelines punish more strongly those who claim to be innocent and that some innocent defendants will plead guilty to avoid the possibility of that increased punishment); Robert E. Scott \& William J. Stuntz, A Reply: Imperfect Bargains, Imperfect Trials, and Innocent Defendants, 101 YALE L.J. 2011, 2012-13 (1992) (arguing that innocent defendants are more risk averse than guilty defendants and are more likely to accept a plea bargain even when a trial probably would vindicate them). 
effect on defendants. Granted, the public normally should repay a defendant for the savings of trial preparation and court resources that flow from a guilty plea. The value of the savings, however, must be discounted by the fact that a guilty plea cuts short the public's chance to learn details about the facts in the case because the factual basis for the plea, as described at the plea hearing, will offer only a quick sketch of the evidence. Prosecutors see an immediate resource savings in the office budget when a defendant pleads guilty, but they might undervalue the need for public awareness of the details that prosecutors already know about the crime and investigation. ${ }^{87}$ Prosecutors with such a blind spot might offer overly large discounts to the defendant.

A guilty plea discount, in addition to rewarding the defendant for saving the government trial resources, also reflects the uncertainty that a defendant saves the government by pleading guilty. There are some forms of uncertainty, however, that the public should resolve only through a trial, even if the defendant offers to remove all risk from the case. When a defendant accepts a steep discount to waive a trial that carries only a remote chance of conviction beyond a reasonable doubt (say, a 20\% chance), this is no cause for rejoicing. Many features of the criminal trial, from the rules of evidence to the standard of proof, declare the importance of a high level of confidence in criminal convictions. ${ }^{88}$ When uncertainty about the accuracy of a conviction becomes too high, the public should not be willing to accept

${ }^{87}$ See Gifford, supra note 86, at 70-73 (describing the benefits of the trial process for the community, and especially for the victim, affected by a given crime); Abraham S. Goldstein, Converging Criminal Justice Systems: Guilty Pleas and the Public Interest, 49 SMU L. REV. 567, 570-77 (1996) (proposing techniques to protect the public interest in a system given over to party initiative and party control); Kenneth Kipnis, Plea Bargaining: A Critic's Rejoinder, 13 LAW \& SOC'Y REV. 555, 556-57 (1979) (explaining how the public benefits from open jury trials).

In some notorious cases that implicate the integrity of criminal justice (for instance, prosecutions of wealthy or famous defendants that raise questions about the even-handed quality of enforcement), the public can benefit enormously from a public airing of the alleged offense and the government's investigation. See, e.g., Barry Meier, 2 Guilty in Fraud at a Cable Giant, N.Y. TIMEs, Mar. 7, 2004, at A1 (discussing the background and verdict of the Adelphia case); Jury Finds Stewart Guilty on All Counts, L.A. TIMES, July 9, 2004, at C2 (reporting on the verdict in Martha Stewart's trial for conspiracy, obstruction of justice, and lying to investigators). Such a public airing would be especially important for cases filed in areas where social attitudes are in flux, such as possession of medicinal marijuana or hate crimes.

${ }^{88}$ Even defenses based on the likely exclusion of reliable but illegally obtained evidence should be considered in examining the necessary public confidence in criminal proceedings. One aspect of the public legitimacy of criminal proceedings is the confidence that law enforcement officers respect the relevant legal constraints. 
the conviction, even when the defendant offers it. ${ }^{89}$ Because the criminal system emphasizes public responses to alleged violations of public values, the need to demonstrate the legitimacy of the criminal justice system must trump the preferences of defendants. At some point, the purchase of too many uncertain convictions undermines our confidence that the system is leading to the accurate results necessary for legitimacy.

The trial distortion theory, therefore, promotes guilty plea negotiations and sentence practices that offer only modest plea discounts to defendants. In setting the legal requirement that a plea of guilty be "voluntary," trial distortion theory defines improper coercion to include any discounts offered in weak cases that are large enough to undermine confidence in the outcome. ${ }^{91}$ If cases of a given evidentiary strength produce a certain pattern of trial outcomes (say, a conviction in two out of every three cases), plea negotiations should produce a similar pattern of outcomes. Better to have confidence in the accuracy of two convictions with sentences near full strength, along with one dismissal or acquittal, than to negotiate for three convictions that produce weaker sentences and inspire weaker confidence.

According to these guiding principles, federal plea practices under current sentencing law present a risky proposition. Granted, the ample resources of the federal system do allow agents to build solid evidentiary foundations for many cases. But even in weaker cases

${ }^{89}$ To put the point another way, while "cost bargaining" is acceptable under the trial distortion theory, the most extreme cases of "odds bargaining" are not. See Francis James, Effective Plea and Sentence Bargaining in South Africa, Just 'CAUSE (Vera Inst. of Just., New York, N.Y.), Jan.-Feb. 2003, at 3 ("[I]f accused defendants who were guilty knew for certain the outcome of a plea of guilty, they would, in fact, plead guilty .... Poorly implemented, however, plea bargaining could erode the quality of justice by encouraging the innocent to plead guilty and undermine public confidence in the administration of justice."); cf. Marc Miller \& Norval Morris, Predictions of Dangerousness: An Argument for Limited Use, 3 Violence \& Victims 263, 278-79 (1988) (drawing a distinction between the level of proof required at trial and the level of certainty necessary to support the use of predictions about a defendant's dangerousness); Moohr, supra note 67, at 214-16 (arguing that public trials provide a rationale for sentences, educate the business community about the illegality of specific conduct, and strengthen the shared social norms of the business community against fraud).

${ }^{90}$ See FED. R. CRIM. P. 11 (b) (2) ("Before accepting a plea of guilty or nolo contendere, the court must address the defendant personally in open court and determine that the plea is voluntary and did not result from force, threats, or promises (other than promises in a plea agreement).”).

${ }^{91}$ Cf. Strickland v. Washington, 466 U.S. 668, 694 (1984) (holding that the prejudicial effect of substandard attorney performance can lead to reversal when it creates prejudice sufficient to undermine confidence in the outcome, and thus adopting a standard lower than preponderance of the evidence). 
(where the risk of trial distortion is greatest), federal prosecutors have little to fear. The penalties they can impose on defendants start well above the typical penalties that most states would impose. ${ }^{92}$ As we will see, current sentencing law gives prosecutors and judges many ways to reward cooperation, yet the discounts they offer still result in sentences higher than the norm in the state system. Sentence severity in the federal system today carries a built-in risk that the plea discount will become too large and distort hypothetical trial outcomes.

\section{Are Lost Acquittals and Dismissals Trial Distortions?}

Where do acquittal rates fit into this world centered around the hypothetical results that trials would produce? A trial distortion theory does not imply that there is a particular level of acquittals that is healthy or unhealthy; acquittals become a point of concern not simply when they become too high or low in absolute terms, but also when they change persistently in one direction. ${ }^{93}$ Moreover, the meaning of lower acquittal rates will differ from place to place. In some places, acquittals dwindle because plea bargains are being offered and accepted in weaker cases. In other places, however, lower acquittal rates show that prosecutorial screening and trial performance are improving.

Let us first explore the more discouraging scenario: when dropping acquittal rates show that more innocent defendants are being convicted. The number of defendants in weak cases who accept plea offers should rise over time if prosecutors or judges increase the trial penalty. These increases could result from changes in the law (say, the passage of a new mandatory-minimum sentencing law that gives

\footnotetext{
${ }^{92}$ Although state sentences actually served tend to be lower than the federal sentences served, federal penalties in general do not exceed public expectations for punishment. See United States v. Wilson, 350 F. Supp. 2d 910, 916-19 (D. Utah 2005) (noting that penalties for some crimes under the Federal Sentencing Guidelines generally tracked respective state sentences as well as public opinion); PETER H. ROSSI \& RICHARD A. Berk, Public Opinion ON SENTEnCING Federal Crimes 79-81 (1995), http://www.ussc.gov/nss/jp_ch5.pdf (summarizing survey responses regarding just punishment for a series of hypothetical cases, and finding that the central tendency of public opinion roughly matches guideline ranges for crimes, with exceptions for some drug crimes, bank robbery, and some fraud offenses).

${ }_{93}$ Movements in either direction could tell us something about the quality of results in the justice system. A sustained increase in acquittals might reveal that some prosecutors are losing touch with the values of jurors and the community, or it could indicate sloppy investigations. The guilty pleas resulting from such a system might deserve some special scrutiny. But the more pertinent problem in the current federal system (and probably in many state systems, as well) is a persistent decline in acquittals.
} 
the prosecutor a new bargaining chip) ${ }^{94}$ or from a change in policy or practice (perhaps an emphasis by a newly elected prosecutor on filing habitual-felon charges whenever possible). ${ }^{95} \quad$ The discount can become quite large; some estimates peg the guilty plea discount at roughly half the length of sentences received after conviction at trial. ${ }^{96}$

Losses in at least some types of dismissals might also indicate trial distortion at work. Dismissals include decisions by judges to terminate a case before the end of trial because of inadequate evidence or some other problem. These dismissals are functionally similar to acquittals,

${ }^{94}$ See Drug Mandatory Minimums: Are They Working?: Hearing Before the Subcomm. on Criminal Justice, Drug Policy, and Human Resources of the H. Comm. on Gov't Reform, 106th Cong. 62 (2000) (statement of John Roth, Chief, Narcotic and Dangerous Drug Section, Criminal Div., Dep't of Justice) (stating that mandatory-minimum sentences for drug crimes provide "an indispensable tool for prosecutors" to induce defendants to cooperate).

${ }^{95}$ For an example of the range of charges available to a federal prosecutor to respond to a given set of facts, consider the case of Nathaniel Heatwole. This student at the Quaker-affiliated Guilford College hid box cutters on airplanes to expose weaknesses in airport security. Federal prosecutors originally charged him with a felony (taking a dangerous weapon aboard an aircraft) with a ten-year maximum sentence. After plea negotiations, prosecutors changed that charge to a misdemeanor with a maximum penalty of six months in prison and a $\$ 5,000$ fine. Associated Press, Box Cutter Student Cops Plea, Makes Video to Aid Screeners, USA TODAY, Apr. 24, 2004, http://www.usatoday.com/travel/news/2004-04-24-box-cutters_x.htm. He was ultimately sentenced to two years supervised probation, 100 hours of community service, and a $\$ 500$ fine. Associated Press, Student in Box-Cutter Case Gets Probation, NewsMAX.COM, June 24, 2004, http://www.newsmax.com/archives/articles/2004/6/24/ 122102.shtml.

${ }^{96}$ For estimates of the size of the trial penalty, see David Brereton \& Jonathan D. Casper, Does It Pay To Plead Guilty? Differential Sentencing and the Functioning of Criminal Courts, 16 LAW \& SOC'Y REV. 45, 55-56 (1981); Richard S. Frase, Implementing Commission-Based Sentencing Guidelines: The Lessons of the First Ten Years in Minnesota, 2 CORNELL J.L. \& PUB. POL'Y 279, 316-19 (1993) (finding that defendants found guilty at trial were significantly more likely to receive a prison sentence than those who pled guilty); Nancy J. King et al., When Process Affects Punishment: Differences in Sentences After Guilty Plea, Bench Trial, and Jury Trial in Five Guidelines States, 105 COLuM. L. REV. 959, 973-75 (2005) (estimating the guilty plea discount for different crime types); Thomas M. Uhlman \& N. Darlene Walker, "He Takes Some of My Time; I Take Some of His": An Analysis of Judicial Sentencing Patterns in Jury Cases, 14 LAW \& SOC’y REv. 323, $327-37$ (1980) (presenting the occurrence of a guilty plea discount in Metro City data); Hans Zeisel, The Disposition of Felony Arrests, 1981 AM. B. FOUND. RES. J. 407, 444-49 (estimating, in one selection of cases, a $42 \%$ increase in severity from sentences offered in exchange for guilty pleas to those eventually imposed following trial); Comment, The Influence of the Defendant's Plea on Judicial Determination of Sentence, 66 YALE L.J. 204, 207 (1956) ("[Judges'] estimates of the extent to which the fine or prison term was diminished for a defendant pleading guilty varied from 10 to 95 per cent of the punishment which would ordinarily be given after trial and conviction." (footnote omitted)). 
so a decrease in this type of dismissal would mean roughly the same thing to defendants as a decrease in acquittals. ${ }^{97}$

Dismissals also include decisions by prosecutors to terminate cases early. Prosecutors commonly dismiss a case after reviewing the file or interviewing the witnesses and realizing that the preliminary reading of the evidence was overly optimistic. If guilty pleas replace dismissals that correct such inadvertent overcharges, they distort the outcomes that would have emerged from the trial process.

Dismissals could also happen when a prosecutor finds it necessary to correct a deliberate overcharge. Under this scenario, after a prosecutor asks for a plea of guilty to an untenable charge ("It never hurts to ask"), the defendant is not fooled and declines the offer, and the prosecutor gives up on the ruse and dismisses the case. ${ }^{98}$ A decline in this type of prosecutor dismissal could indicate that more defendants are taken in by the maneuver (and are pleading guilty to unfounded charges), a troubling prospect under the trial distortion theory. ${ }^{99}$ But a decline in dismissals might also indicate that prosecutors are making fewer of these gambits in the first place, which would be good news for trial distortion purposes. Thus, given these various sub-types that point in different directions, dismissals send out even more ambiguous trial-distorting signals than acquittals do.

\section{The Accuracy Hypothesis}

As we have seen, there is an alternative explanation for declines in both acquittals and dismissals, one with more benign implications than a trial distortion theory. Instead of postulating that fewer acquittals result from more defendants abandoning viable defenses because of a higher trial penalty, such lower acquittal rates might simply mean that the quality of cases filed is improving over time. This "accuracy hypothesis" could prove true if prosecutors screen cases more care-

${ }^{97}$ Acquittals have different appeal and double jeopardy consequences than some dismissals by judges. See United States v. Sanges, 144 U.S. 310, 312-13 (1892) (finding that following the acquittal of a defendant, the State can neither appeal nor seek a new trial).

98 See Model Rules of Prof'L CONDUCt R. 3.8(a) ("The prosecutor in a criminal case shall ... refrain from prosecuting a charge that the prosecutor knows is not supported by probable cause ....").

99 See Joseph A. Colquitt, Ad Hoc Plea Bargaining, 75 Tul. L. Rev. 695, 740-41, 75058 (2001) (criticizing bargains for pleas of guilty to nonexistent, inapplicable, or timebarred crimes, and arguing that judges should reject those bargains). If the prosecutor overcharges the case but the defendant ultimately pleads guilty to a lesser charge to which she has no viable defense, then the prosecutor's charging decision amounted to harmless error and the case presents no problems for trial distortion purposes. 
fully as they enter the system or if investigators assemble stronger cases in the first place. ${ }^{100}$ It could also happen if prosecutors solidify cases after they are filed through more complete preparation for trial. ${ }^{101}$ If cases were strengthened in this way, a drop in the acquittal rate would accurately reflect the government's better prospects at trial, and would not indicate any distortion of trial outcomes during plea negotiations. $^{102}$

A prosecutor's office that receives more resources (whether it be new funding from the legislature or more available hours because fewer existing cases go to trial) could spend those resources either on extra quantity or on extra quality. When the new resources buy extra quantity, newly added cases are likely to involve less serious crimes or less persuasive evidence, because the office would have already selected the highest priority cases with the first available funds. ${ }^{103}$

When new resources buy extra quality, however, the system outcomes change to reflect the better truth-finding function of the system. Improvements in case screening would shift careful prosecutorial scrutiny of the case to the pre-charge stage and would consequently drive down the dismissal rates. ${ }^{104}$ An investment in higher-quality case screening might also lead to lower acquittal rates.

${ }^{100}$ See Wright \& Miller, supra note 23, at 116-17 (concluding that principled screening in New Orleans created positive outcomes while reducing reliance on plea bargains); Note, The Elimination of Plea Bargaining in Black Hawk County: A Case Study, 60 IOWA L. REV. 1053, 1066-69 (1975) (finding that improved screening in an Iowa county accounted for the fact that, despite the elimination of guilty pleas, the conviction rate remained unchanged).

${ }^{101}$ See Bruce H. Kobayashi \& John R. Lott, Jr., In Defense of Criminal Defense Expenditures and Plea Bargaining, 16 INT'L REV. L. \& ECON. 397, 407-11 (1996) (finding that appropriate prosecutorial preparation leads to guilty defendants receiving more overall punishment than innocent defendants).

102 See Finkelstein, supra note 14, at 306-07 (noting that acquittal and dismissal rates in different districts are based on a similar mix of crimes charged). But cf. Alschuler, supra note 19, at 28 n.151 (discussing Finkelstein's failure to examine in depth the possible differences in charging and evidentiary quality from district to district).

${ }^{103}$ See Michael M. O'Hear, Sentencing the Green-Collar Offender: Punishment, Culpability, and Environmental Crime, 95 J. CRIM. L. \& CRIMINOLOGY 133, 181-83 (2004) (arguing that the increased number of environmental prosecutions likely reflects the fact that more marginal cases are being brought). The new cases added with the additional resources will not necessarily be the least serious in the mix, if the resources arrive as perceptions are shifting about which crimes are serious. For instance, if methamphetamine cases receive higher priority just as prosecutors find extra resources to devote to them, the new cases will not be perceived as the least serious charged.

${ }^{104}$ If a prosecutor's office adopts poor screening structures, a case that is too weak might get filed before the prosecutor reviews it carefully. When an overworked prosecutor finally turns to the case for trial preparation and discovers its weaknesses, dismissal is a better option than going to trial with only slim chances of success. 
Roughly speaking, stronger cases selected at the start should produce stronger results at trial for the government. ${ }^{105}$ Similarly, if improved preparation reveals flaws in the evidence that can be remedied (for instance, a witness who needs additional documentary support to tell the truth convincingly) the acquittal rate should go down. ${ }^{106}$

Thus, the tradeoff between quantity and quality of cases could offer an important clue as to whether dropping acquittals in a particular system present good news (the accuracy hypothesis) or bad news (trial distortion). Based on this criterion, it appears that the most recent era in federal criminal justice is the most worrisome, for reasons we will now explore.

\section{WHAT MADE FEDERAL ACQUITTALS DISAPPEAR?}

So far, I have argued that the combination of higher guilty plea rates and lower rates of acquittal in a jurisdiction creates a real source of concern. Why did these outcomes shift over time in the federal system? In this section, I concentrate on the most likely causes for two eras of noteworthy change: the guilty plea decreases of the 1950s and 1960 s and the guilty plea increases from the 1980s to the present. Part IV will narrow the focus to consider in more detail the troubling developments in the most recent decade.

The causation story changes as we move from one era to the next. Some earlier changes in guilty plea and acquittal rates may have reflected an increasingly accurate system, probably based on improvements in access to defense counsel and lower workloads for judges. Developments in the last twenty-five years, however, were more likely the result of prosecutorial negotiation techniques that distorted trial

${ }^{105}$ It is possible that high-quality case screening can coexist with high acquittal rates. Some prosecutors' offices that set consistently demanding standards for the filing of cases nevertheless take some calculated risks and lose a relatively large number of cases at trial. See, e.g., Wright \& Miller, supra note 23, at 76-77 (describing the relatively high rate of acquittals in New Orleans).

${ }^{106}$ If extra trial preparation reveals fatal flaws in more cases, it would probably increase the dismissal rate because the prosecutor would not often forge ahead to try a hopeless case.

Economic theory might suggest that prosecutors probably devote more marginal new resources to case screening and negotiating efforts than to improved trial preparation. Attorneys always give high priority to trial preparation because trials are such visible events with an impact on the prosecutor's professional reputation; put in economic terms, trial preparation resembles a fixed cost, while the quality of case screening and the quantity of cases reviewed for possible charges both look more like variable costs. Cf. Lynch, supra note 84, at 130-31 (arguing that lawyers may rise to the occasion when in the constructively adversarial environment of a trial, but that more variation exists in the quality of counsel during plea negotiations). 
outcomes. In particular, federal sentencing law over those decades changed to give prosecutors and judges greater ability to impose an ever larger and more certain penalty on defendants who go to trial. It has become far too costly in federal court to claim and prove innocence.

\section{A. Case Volume}

The volume of defendants and cases passing through American criminal justice systems increased throughout the twentieth century. ${ }^{107}$ As time in the criminal courtroom grew scarcer, a major time-saver grew to dominate the system. Not surprisingly, then, many historians of plea bargaining point to rising workloads of criminal justice actors as the best explanation for their embrace of plea bargains. ${ }^{108}$

In the federal system, this account holds some weight, but the role of case volume and workload is complex. Once we adjust for the increasing number of judges and prosecutors assigned to the system over the years, we see that case volume has had mixed effects on guilty plea and acquittal rates. As the discussion in this section demonstrates, a lighter workload for judges over the years produced fewer guilty pleas and more acquittals, but lighter workloads for prosecutors over time led to just the opposite result: more guilty pleas and fewer acquittals.

We can explore caseload at the simplest level by tracing the volume of cases moving through the system each year. In gross terms, higher federal case volume did seem to produce higher guilty plea rates. The increases in guilty plea rates that began in the 1980s hap-

107 RULE OF LAW 29-30 (1996) (providing statistics indicating both increased crime and increased incarceration).

${ }^{108}$ See, e.g., Markus Dirk Dubber, American Plea Bargains, German Lay Judges, and the Crisis of Criminal Procedure, 49 STAN. L. REV. 547, 574-77 (identifying a German statute "designed specifically to ... alleviate the workload of judges and prosecutors," which "significantly contributed to the expansion of plea bargaining"); Fisher, supra note 11, at 865 (noting that prosecutors in the nineteenth century "plea bargained to ease their crushing workloads"); Note, Restructuring the Plea Bargain, 82 YALE L.J. 286, 286 (1972) (arguing that plea bargaining is necessary because the American system renders it "impossible for every defendant to claim his right to a jury trial"). For the view repudiating the importance of caseload, see Jo Dixon, The Organizational Context of Criminal Sentencing, 100 AM. J. SOC. 1157, 1177 (1995) for examples of studies demonstrating that plea rates are unrelated to caseload; also useful is Stephen P. Lagoy et al., An Empirical Study on Information Usage for Prosecutorial Decision Making in Plea Negotiations, 13 AM. CRIM. L. REV. 435, 462 (1976), which provides, "It appears that where case load pressures were less, there was actually a greater probability of the acceptance of a plea bargain." 
pened alongside annual increases in the number of defendants moving through the system. ${ }^{109}$ At first glance, the connection is also fairly strong between case volume and acquittal rates. The last three decades have been typical: as case volume increased, acquittals decreased. ${ }^{110}$

Despite the apparent connection between volume on the one hand and acquittal and guilty plea rates on the other, raw case volume is a misleading proxy for the caseloads that prosecutors and judges actually face when processing cases. As the total volume in the system increases, legislatures periodically add capacity to the system by funding new prosecutors and judges. ${ }^{11}$ Thus, a doubling of the case volume might produce no real change in the caseload for individuals if the number of prosecutors and judges also eventually doubles.

The connection between case volume and guilty plea rates and acquittal rates weakens substantially after adjusting the annual criminal caseload in light of the number of federal judges and prosecutors at work in those years. The spectacular influx of cases during Prohibition, however, did produce a link between increased workload and decreased acquittals. During those thirteen years, the number of prosecutors and judges never had time to catch up with the increase in cases. ${ }^{112}$ During later periods, however, when the growth in volume

${ }^{109}$ The number of defendants in terminated cases rose from 44,585 in 1971 to 78,835 in 2002 . The correlation over time between guilty plea rates and sheer volume, however, is not perfect. For instance, the volume of defendants stayed fairly steady from 1951 to 1971, when guilty plea rates dropped and acquittal rates climbed back up. By 1956, the caseload was between 30,000 and 40,000 defendants, where it remained even during the long slide in guilty pleas until 1971. Guilty plea rates and volume figures part ways at other points as well. In the period before Prohibition, guilty plea rates actually began their steep climb in 1912, before volume had picked up very much. See Statistical Appendix, supra note 13, at app. 1.

One statistical measure of the match between two sets of numbers, a Pearson's correlation coefficient, was moderately strong for the overall period, 1910-2002, at 0.54 .

${ }^{110}$ The correlation between acquittal rates and volume of cases terminated during the period from 1910 to 2002 equals -0.73 ; the correlation for the period from 1945 to 2002 is similarly strong, at -0.74 .

${ }^{111}$ Cf. Richard T. Boylan, Fiscal Federalism and the War on Drugs 1 (Nov. 29, 2003), available at http:/ / papers.ssrn.com/abstract=474161 (discussing how "a higher fraction of drug incarcerations are federal in states ... with lower per-capita income," indicating that these states are less capable of prosecuting drug cases at the state level).

${ }^{112}$ See ALI, supra note 26, at 57 (explaining that during Prohibition, the criminal justice system was "not geared to handle this increase in business"); Alschuler, supra note 19, at 32 (suggesting that the end of Prohibition might explain the drop in guilty pleas between 1920 and 1936); John F. Padgett, Plea Bargaining and Prohibition in the Federal Courts, 1908-1934, 24 LAW \& SOC'Y REv. 413, 419-24 (1990) (discussing "guilty pleas as a response to caseload" before and during Prohibition). 
was more incremental and allowed the addition of new judgeships and prosecutor positions, volume had much weaker effects. Surprisingly, the average number of cases terminated per judge and per prosecutor declined over the years because the number of new judges and prosecutors outpaced the rise in case volume.

In the specific context of judicial criminal caseload, the average number of criminal cases terminated per district court judge declined consistently from 1950 to 1981 and then rose modestly during the last two decades, as Table 2 shows. ${ }^{113}$ When judges had more time to devote to criminal cases, the guilty plea rate tended to fall and the acquittal rate tended to rise: the judicial workload fell along with the guilty plea rate from the 1950s through the 1970s. The gentle rise in the judicial criminal caseload since 1981 corresponded with the large increase in the guilty plea rate and large decrease in the acquittal rate. $^{114}$

${ }^{113}$ The criminal cases flowing through the federal courts are not the only source of caseload pressure. Particularly for the judges, an expanding civil docket creates pressure to dispose of all cases more quickly. Fisher, supra note 11, at 867 ("As judges devoted a hugely increasing proportion of their time to the civil caseload, they devoted a shrinking proportion to the criminal caseload, and they resolved more and more criminal cases by guilty plea."). The number of civil cases filed has increased more quickly than the number of cases on the criminal docket over the last sixty years, possibly causing judges to be more amenable to guilty pleas in order to clear their criminal dockets more efficiently. See Marc Galanter, The Vanishing Trial: An Examination of Trials and Related Matters in Federal and State Courts, 1 J. EMPIRICAL LEGAL STUD. 459, 492 (2004) (noting the disparity in the two dockets' increase, and suggesting a causal connection between the more dramatic increase in civil caseloads and guilty pleas).

Between 1945 and 2002, the combined caseload per judge fluctuated several times. Between 1945 and 1968, the combined judicial caseload dropped from 542 to a low of 311 . The caseload then increased for a time, up to a high of 640 in 1985, before dropping back to around 550 in the last few years. More detailed combined caseload numbers appear in the Statistical Appendix, supra note 13, at app. 3.

The match between these combined judicial caseloads and guilty plea rates is tolerably good, but imperfect. The long decline in guilty pleas from 1951 to 1971 mostly coincided with a decreased judicial caseload, and the first half of the sustained rise in guilty pleas during the last three decades matched a rise in the judicial caseload. When judges had more time for each case, apparently they did not encourage guilty pleas so strongly. Since 1985, however, the connection between these factors has disappeared. See Statistical Appendix, supra note 13, at app. 3.

${ }_{114}$ More specific judicial criminal workload numbers appear in the Statistical Appendix, supra note 13, at app. 3. 
Table 2: Criminal Cases Terminated per Judge and per Prosecutor in Federal Courts, 1950-2000

\begin{tabular}{lll} 
& $\begin{array}{l}\text { Cases per } \\
\text { Prosecutor }\end{array}$ & $\begin{array}{l}\text { Cases per } \\
\text { Judge }\end{array}$ \\
\hline \hline 1950 & - & 183 \\
\hline 1955 & - & 171 \\
\hline 1960 & 51 & 137 \\
\hline 1965 & 50 & 117 \\
\hline 1970 & 37 & 111 \\
\hline 1975 & 33 & 128 \\
\hline 1980 & 19 & 76 \\
\hline 1985 & 21 & 95 \\
\hline 1990 & 19 & 106 \\
\hline 2000 & 13 & 91 \\
\hline & 15 & 123 \\
\hline
\end{tabular}

The match, however, between judicial criminal caseload on the one side and guilty plea or acquittal rates on the other side is imperfect. Some years were mismatches; in addition, the guilty plea and acquittal rate changes over the last two decades were much stronger than the gradual increases in judicial criminal caseloads. Overall, there was only a weak correlation between judicial criminal caseload on the one hand and guilty plea or acquittal rates on the other. ${ }^{115}$

Although the fact is counterintuitive, the criminal caseload of prosecutors also appears to have become lighter over the last four decades. Unlike the judicial caseload, which fluctuated over time, the prosecutor caseload fell pretty steadily during the last half of the twentieth century. The average number of criminal cases terminated per prosecutor was about fifty-five in 1958, but, as Table 2 shows, by 1980 it was down to nineteen, in the same neighborhood as the current figure. ${ }^{116}$ Thus, the expansion in the number of federal criminal prose-

${ }^{115}$ Between 1945 and 2002, the correlation coefficient between judicial criminal caseload and the guilty plea rate was 0.20 ; the correlation between judicial criminal caseload and the acquittal rate was -0.15 .

${ }^{116}$ The number of Assistant U.S. Attorneys rose from 582 in 1958 to 5304 in 2002. See Statistical Appendix, supra note 13, at app. 3. More specific prosecutor workload numbers appear in the Statistical Appendix. Id. The workload calculation used here (total number of cases terminated in a year divided by the average number of Assistant U.S. Attorneys employed during that year) is imperfect because it includes both civil and criminal litigators, but a more precise breakdown is not available for a long span of years. For an example of a similar calculation, see Michael Edmund O'Neill, When 
cutors more than compensated for the increased criminal case volume in the federal courts over the years. ${ }^{117}$

New prosecutor positions outpaced new case volume from the 1950 s to 1990 , meaning that prosecutors had more time to devote to each case on average. Perhaps the new resources went into higher quality rather than greater quantity of cases. ${ }^{118}$ Two time periods, however, cast a more negative light on the effect of prosecutor caseloads. First, prosecutor caseloads fell even during periods when acquittal rates rose, such as the 1960s. Second, prosecutor caseloads stayed constant from 1990 to the present, a period of sharply falling acquittal rates. ${ }^{119}$

These patterns do not speak well for the accuracy hypothesis. Since acquittal rates increased during some periods when the overall prosecutor caseload decreased, it is difficult to maintain that federal prosecutors used their extra time to produce more accurate results through screening cases more accurately or preparing more thoroughly for trial. Moreover, since caseloads stayed flat during the most recent drop in acquittal rates, it is hard to believe that extra prosecutor efforts in each case produced more accurate outcomes during this period.

Prosecutors Don't: Trends in Federal Prosecutorial Declinations, 79 NOTRE DAME L. REV. 221, 258-59 (2004) (combining both civil and criminal litigators).

${ }^{117}$ The effect of the increasing civil docket on plea bargaining could also reach prosecutors, although the impact should be slight, as the U.S. Attorneys' offices devote separate staff to civil litigation. When we count only civil cases involving the government as a litigant, civil and criminal cases per prosecutor decreased from the 1950 s to 1974, increased for the next decade, and then decreased again from 1985 to 2002. Again, as with the criminal caseload, the decline in combined caseload per prosecutor happened early, and flattened out in recent years. See Statistical Appendix, supra note 13, at app. 3.

${ }^{118}$ A law enforcement agency such as the FBI might also aim for quality over quantity, meaning that as the cases get more factually complex and varied, the amount of time needed to reach a minimum level of competence for each case increases. See, e.g., M. Elaine Nugent \& Mark L. Miller, Basic Factors in Determining Prosecutor Workload, Prosecutor, July-Aug. 2002, at 32, 36 (concluding that criminal cases with "complications" have longer "case processing times"); $f$. LAWRENCE M. FRIEDMAN \& ROBERT V. PERCIVAL, The RoOTS OF Justice 194-95 (1981) (concluding that the increased rate in plea bargains resulted from the professionalization of police and prosecutors and from increased reliance on law enforcement); Padgett, supra note 112, at 441-44 (stating that the professionalization of the FBI during the 1920s led to stronger evidence and contributed to declining acquittal rates in that decade).

${ }^{119}$ Prosecutor workloads correlated more strongly than judicial criminal workloads with guilty plea and acquittal rates. The correlation between prosecutor caseload and guilty plea rates for the period from 1958 to 2002 was moderately strong, at -0.45 . The correlation between prosecutor workload and acquittals was even stronger, at 0.62 . 


\section{B. Legal Complexity and Defense Counsel in the 1950s and 1960 s}

The legal tools available to criminal judges, prosecutors, and defense lawyers change over time. When legal rules change to create more cumbersome trials, in theory guilty plea rates should rise because the legal actors (especially the prosecutors and judges) have greater incentive to avoid trials. ${ }^{120}$

These general observations about criminal adjudication, however, did not play out as predicted in the federal system. The federal criminal court rules became more complex during the 1950s and 1960 s, but the rule changes that made trials more expensive actually contributed to rising trial rates and acquittals during that era. The most important legal changes of that era, especially the widespread availability of defense counsel, gave more complete information to defendants about the strength of the government's case and made a threat to go to trial more credible.

During some earlier eras in federal criminal justice, simpler legal rules made it possible to conduct cheaper trials, and more trials did result, just as one might predict. ${ }^{121}$ But the profound legal changes that reshaped federal criminal justice in the $1950 \mathrm{~s}$ and $1960 \mathrm{~s}$ also made it clear that some forms of procedural complexity-laws that make trials more expensive-can nevertheless cause trial rates to go up. The longest sustained rise in federal criminal trial rates happened

${ }^{120}$ See, e.g., WAYNe R. LAFAve ET AL., Criminal Procedure $\$ 21.1$ (b) (4th ed. 2004) (listing "the broadening of the right to counsel" and "the due process revolution" among the reasons for the expansion of guilty pleas); Malcolm M. Feeley, Legal Complexity and the Transformation of the Criminal Process: The Origins of Plea Bargaining, 31 ISRAEL L. REV. 183, 218 (1997) (finding that "as trials became more vigorous and complex, lawyers came to rely on an alternative, the guilty plea"); John H. Langbein, Understanding the Short History of Plea Bargaining, 13 LAW \& SOC'Y REV. 261, 264 (1979) (describing the relative simplicity of trials in the time before plea bargaining became common); see also David L. Cook et al., Criminal Caseload in U.S. District Courts: More Than Meets the Eye, 44 AM. U. L. REV. 1579, 1593-94 (1995) (suggesting that the number of criminal cases understates true workload because criminal cases have become more lengthy).

${ }^{121}$ See Alschuler, supra note 19, at 42 ("The simpler and more straightforward the trial process, the more likely it is that the process will be used."). Bench trials, which are usually simpler and less expensive than jury trials, became available in the federal courts in the 1930s, a time when guilty plea rates did fall. See Patton v. United States, 281 U.S. 276, 312 (1930) (holding that the defendant may waive her constitutional right to a jury trial); FED. R. CRIM. P. 23(a) (stating that if a defendant is entitled to a jury trial, the defendant must have such a trial unless the defendant waives it in writing, the government consents, and the court approves). However, the simplifying effect of federal bench trials did not last long, and by the 1940s guilty pleas increased again even while the number of bench trials continued at their previous levels. See Statistical Appendix, supra note 13, at app. 5 . 
between 1951 and 1971. During these same years, the Warren Court reinterpreted the Constitution to provide federal defendants with several new claims to raise before trial, relating to searches, seizures, interrogations, and identifications. ${ }^{122}$ These changes to the governing trial procedures had some effect on the cost of trials, as seen through an increase in the average length of a federal trial as the decades passed. ${ }^{123}$

Although many legal changes contributed to the length and complexity of trials, the right to defense counsel in particular probably helped decrease the guilty plea rates for a time. The drop in guilty plea rates between 1951 and 1971 coincided with the emergence of the right to defense counsel in routine federal criminal cases. This right to appointed counsel in federal court, first recognized as a constitutional requirement in $1938,{ }^{124}$ did not become an everyday reality until more than two decades passed. Federal defendants who could not afford an attorney (an estimated one-third to one-half of all federal defendants at that time) received appointed lawyers, ${ }^{125}$ but those lawyers received neither compensation nor funds to pay for expert

${ }^{122}$ See Mapp v. Ohio, 367 U.S. 643, 656-57 (1961) (enforcing the exclusion of evidence obtained by unlawful seizure); Miranda v. Arizona, 384 U.S. 436, 471 (1966) (ruling that an individual held for interrogation must be informed of her right to consult with an attorney and to have the attorney present during police interrogation); United States v. Wade, 388 U.S. 218, 226-27 (1967) (requiring court scrutiny of all pretrial confrontations of the accused to determine if presence of counsel is necessary for a fair trial); Spinelli v. United States, 393 U.S. 410, 418 (1969) (reinforcing a high standard of accuracy in identifications); $c f$. Ronald F. Wright, How the Supreme Court Delivers Fire and Ice to State Criminal Justice, 59 WASH. \& LEE L. REv. 1429, 1432-38 (2002) (explaining how the Warren Court forced a shift in police practices and courtroom customs).

${ }^{123}$ In the 1950 s, criminal trials averaged less than two days each. The average increased through the years to a high of 3.48 days in 1997, before falling slightly over the last five years. Estimates of trial length, based on data from the AOUSC, appear in the Statistical Appendix, supra note 13. But the longer criminal trials in federal court occurred during both the increases and the decreases in the guilty plea rates. They also occurred regardless of whether acquittal rates were high or low.

${ }^{124}$ Although a 1790 statute provided for appointed counsel in some capital cases, Act of Apr. 30, 1790, ch. IX, § 29, 1 Stat. 112, 118, the constitutional requirement was not announced until Johnson v. Zerbst, 304 U.S. 458, 469 (1938). See also Evans v. Rives, 126 F.2d 633, 638 (D.C. Cir. 1942) (holding that the right to counsel in all criminal prosecutions is not limited to felonies); David Fellman, The Constitutional Right to Counsel in Federal Courts, 30 NEB. L. REV. 559, 561-62 (1951) (discussing the legal evolution of the right to counsel in criminal cases).

${ }^{125}$ FED. R. CRIM. P. 44 (1966) (instituting the appointment of lawyers for the indigent in all stages of a criminal proceeding); see also REPORT OF THE ATTORNEY GENERAL'S COMMITTEE ON POVERTY AND THE ADMINISTRATION OF FEDERAL CRIMINAL JUSTICE 16-17 (1963) [hereinafter COMM. REPORT ON POVERTY] (providing results of a study on provision of appointed lawyers). 
witnesses, investigators, or other defense services. The lawyers were also appointed to the case at arraignment, after several important events in the case had already transpired. ${ }^{126}$

The formal right to federal defense counsel became more meaningful in 1964 with the passage of legislation authorizing and funding a national system of federal public defenders and panel attorneys. ${ }^{127}$ As more federal defendants gained practical access to compensated defense lawyers for the first time, they became more likely to go to trial. ${ }^{128}$ The appointed lawyers helped argue for lower bail and advised some defendants during preliminary hearings. ${ }^{129}$ Defense attorneys also provided more defendants with an independent estimate of their odds of victory at trial; in addition, the availability of investigators and experts actually increased their odds of acquittal. ${ }^{130}$

Another legal tool strengthened the position of defendants during this time and may have empowered them to go to trial more often. Congress passed the Bail Reform Act in 1966, which made it easier for federal defendants to gain their release from detention before trial. ${ }^{131}$ Because defendants who remain in detention before trial are more anxious to resolve their cases, they plead guilty more often than defendants who are released pending trial; additionally, because detained defendants cannot assist their attorneys in locating witnesses and evidence, their chances of acquittal are lower. ${ }^{132}$ Thus, changes in pretrial release practices could have contributed to the decrease in

${ }^{126}$ See COMM. REPORT ON POVERTy, supra note 125, at 24 (highlighting the strategic importance of counsel's presence in early stages of the trial).

127 Act of Aug. 20, 1964, Pub. L. No. 88-455, § 3006A, 78 Stat. 552.

${ }^{128}$ See COMM. REPORT ON POVERTY, supra note 125, at 19. The rising trial rates (and corresponding drop in guilty plea rates) during this period are depicted in Figure 1. See also Statistical Appendix, supra note 13, at app. 1. The federal experience appears to conflict with Malcolm Feeley's thesis that plea negotiations increase when more defendants have access to defense attorneys. See Malcolm M. Feeley, Plea Bargaining and the Structure of the Criminal Process, 7 JUST. SYs. J. 338, 340 (1982) (arguing that as resources, including defense counsel, have become more accessible to the accused, the opportunity for negotiation has also increased).

129 See COMM. REPORT ON POVERTY, supra note 125, at 24 (discussing the trialoriented role defense counsel can play in earlier stages in the proceedings).

${ }^{130} I d$. at $26-29$.

131 18 U.S.C. $\$ 3146$ (b) (2000).

132 See Am. BAR Ass'N, StANDARDS RELATING TO THE AdMINISTRATION OF CRIMINAL JUSTICE 237 (1968) ("The fact that a defendant has been detained pending trial should not be allowed to prejudice him at the time of trial or sentencing."); VERA INSTITUTE, TEN YEAR REPORT, 1961-1971, at 18 (1972) ("[T] he detainee is more apt to be convicted than if he were free on bail ...."); Note, Compelling Appearance in Court: Administration of Bail in Philadelphia, 102 U. PA. L. REV. 1031, 1048 (1954) (discussing the negative effects on preparation for trial when a defendant cannot post bail). 
guilty pleas and the increase in acquittals during the late 1960s (although both of these trends began well before the passage of the bail statute). ${ }^{133}$ Similarly, the arrival of pretrial detention under legislation passed in 1984 and upheld three years later against constitutional attack $^{134}$ may have contributed slightly to the increased guilty plea rates and decreased acquittal rates of the 1980s and 1990s (although the rates started moving a few years before the bail reform statute took effect).

It thus appears that many of the same legal changes that made federal trials longer and more complex also made acquittals more realistic for defendants. In particular, the increased prevalence of defense counsel made defendants better informed and less desperate during plea negotiations. These changes in the adversarial testing of each case, in turn, likely improved the accuracy of outcomes in the federal system during the 1960s and 1970s.

\section{Crime of the Decade}

The federal criminal code, even more than state criminal codes, has expanded to cover more and more conduct over the years. ${ }^{135}$ But the real footprint of federal criminal justice is measured not by the reach of the code, but by the number and type of cases actually filed.

${ }^{133}$ See Daniel J. Freed \& Patricia M. WAld, Bail in the United States 63 (Nat'l Conf. on Bail and Criminal Justice: May 26-29, 1964) (showing that $60 \%$ of recommended parolees in New York were acquitted as opposed to the mere $23 \%$ of those who were not recommended).

${ }^{134} 18$ U.S.C. $\$ \S 3141-54$ (1984); see Salerno v. United States, 481 U.S. 739, 755 (1987) (holding that the "provisions for pretrial detention in the Bail Reform Act of 1984 fall within [the] carefully limited" category of acceptable instances of detention).

${ }^{135}$ See AM. BAR ASs'N, THE FEDERALIZATION OF CRIMINAL LAW 7-11 (1997) (revealing that more than $40 \%$ of federal criminal statutes were enacted over the past thirty years); John S. Baker, Jr., Measuring the Explosive Growth of Federal Crime Legislation 5 (2004) http://www.fed-soc.org/Publications/practicegroupnewsletters/criminallaw/ crimreportfinal.pdf (discussing an ABA report that documents an "explosive growth" in federal criminal law since 1970); 1 FED. COURTS STUdy COMm., Report of the Federal Courts Study Committee, in WORKING PAPERS AND SubCOMmittee RePORTS, July 1, 1990, at 1, 23-39 (attributing the judicial caseload spiral to the recent broad range of statutes creating or implying new federal causes of action); Steven D. Clymer, Unequal Justice: The Federalization of Criminal Law, 70 S. CAL. L. REV. 643, 645 (1997) (discussing the encroachment of the federal criminal code on state criminal laws); L.B. Schwartz, Federal Criminal Jurisdiction and Prosecutors' Discretion, 13 LAW \& CONTEMP. ProBS. 64, 65 (1948) (discussing the extension of federal law into the traditional state realm); see also William J. Stuntz, The Pathological Politics of Criminal Law, 100 MiCH. L. REV. 505, 517 (2001) (arguing that federal criminal law "probably covers more conduct . . than any state criminal code"). 
There are certain constants in the mix of crimes that attract the attention of federal prosecutors. Various forms of fraud and theft have remained staples of the federal docket, occupying between $20 \%$ and $35 \%$ of the cases filed over the last six decades. ${ }^{136}$ But as criminal behavior changes or (more likely) as the priorities of U.S. Attorneys change, the federal criminal docket evolves to reflect these changes as the generations pass. ${ }^{137}$

The shifting mix of crimes prosecuted helps explain the peaks and valleys in the rates of guilty pleas and acquittals. Some crimes are simply easier to prove than others, and some investigating agencies may be especially efficient at assembling the necessary facts to support a criminal conviction. ${ }^{138}$ Whatever the precise reason, a change in the number of certain crimes can shift the overall trends in guilty pleas or acquittals.

The liquor cases filed between 1920 and 1933 offer one possible explanation for a period of high guilty plea rates and low acquittal rates. ${ }^{139}$ In one sense, the liquor cases were not radically different from other federal cases, as they produced acquittal rates and guilty plea rates virtually identical to those seen in the rest of the federal criminal docket. ${ }^{140}$ However, the differential between the sentence imposed after trial and the sentence imposed after a guilty plea (a rough approximation of the trial penalty) was distinct from that of the other cases in the federal docket. The proportion of liquor defendants receiving a prison sentence rose by 28 percentage points when

${ }^{136}$ For the precise figures, see the Statistical Appendix, supra note 13. See also Cook et al., supra note 120, at 1586 (showing that forgery and counterfeiting cases declined dramatically from 1972 to 1994).

${ }^{137}$ For a discussion of the quantity of immigration, automobile theft, bank robbery, and weapons crimes on the federal criminal docket during different eras, see the Statistical Appendix, supra note 13, at app. 4. Since 1995, immigration cases have become more prominent and the high guilty plea rate and low acquittal rate for those cases have shifted the overall case mix. From 1960 to 1980, relatively simple Dyer Act prosecutions had some influence on the criminal docket.

${ }^{138}$ Cf. Lawrence M. Friedman, Plea Bargaining in Historical Perspective, 13 LAW \& SOC'Y REV. 247, 257 (1979) (arguing that plea bargaining resulted less from caseload pressures than from increased quality of proof as a consequence of professionalization of prosecutors and police).

139 See H.R. REP. NO. 71-722, at 56 (1931) (discussing plea bargains in the federal system made necessary by caseload pressures); Rubin, supra note 26, at 496-97 (analyzing the number of criminal prosecutions for violations of the Prohibition Act). The National Prohibition Act used to be at 27 U.S.C. 1 (1919) (repealed 1935).

${ }^{140}$ Based on a sample of cases from thirteen districts, $2.3 \%$ of terminated liquor cases ended in acquittals, versus $2.9 \%$ of terminated non-liquor cases. Comparable numbers also appear for guilty pleas, with $72.6 \%$ of liquor cases ending in guilty pleas, versus $72.5 \%$ of all other cases. ALI, supra note 26 , at 115 . 
the defendants went to trial; for the non-liquor defendants, the sentence increased by only 7 points. ${ }^{141}$

These are evocative numbers when viewed through the lens of trial distortion theory. Apparently, in the liquor cases, federal prosecutors had to offer larger concessions in their recommended sentences before defendants would give up their valuable trial rights. It is possible that the jury appeal of the liquor cases made them systematically weaker than other federal cases. If that was the case, the offers of greater discounts in liquor cases helped to suppress what otherwise might have been a substantial increase in the acquittal rate.

Like the liquor cases, federal narcotics cases also varied in important ways over the years. ${ }^{142}$ The proportion of the federal criminal docket devoted to narcotics cases grew spectacularly in the last half of the twentieth century, with more than a six-fold increase over five decades. ${ }^{143}$

When narcotics crimes constituted a smaller part of the docket, defendants were especially likely to go to trial. In 1951, about $75 \%$ of the drug defendants ended their cases in guilty pleas, compared to $83 \%$ of the total defendant population. During the 1950s and 1960s, the guilty plea rate for drug cases stayed below the rates for other types of crimes, even as the overall rates declined. ${ }^{144}$ But when the guilty plea rates for non-drug crimes rose again in the early 1970s, the plea rates for drug cases increased more quickly and drew closer to the norm. ${ }^{145}$ Thus, as the drug cases asserted a larger and larger role

${ }^{141} I d$. at 141 . The percentage of sentences involving imprisonment for non-liquor convictions was $82.1 \%$ after trial and $75.6 \%$ after a guilty plea. For liquor convictions the percentage was $62.4 \%$ after trial and $34.5 \%$ after a guilty plea. Id.

${ }^{142}$ See Cook et al., supra note 120, at 1583-90 (showing that drug cases fell from 1973 to 1980 , but rose from 1980 to 1994 ).

${ }^{143}$ These crimes accounted for $6 \%$ of the defendants on the federal docket in 1951, 12\% in 1971 (after the passage of a new anti-drug statute in 1970), 21\% in 1973, $30 \%$ in 1988 , and $37 \%$ in 2002 . Narcotics cases are now the largest single category of crime type. Note also that the mix of drug cases shifted decisively over time from possession to distribution cases. See Cook et al., supra note 120, at 1586-87 (showing that while possession filings decreased from $17 \%$ to $14 \%$ from 1972 to 1994 , distribution offenses now make up $74 \%$ of all drug cases).

${ }^{144}$ More details about the guilty plea rates in narcotics cases, compared to the rest of the pool, appear in the Statistical Appendix, supra note 13, at app. 4. The guilty plea rate was $63 \%$ in 1956 and $64 \%$ in 1961. Id.; see also BUREAU OF JUSTICE STATISTICS, U.S. DEP'T OF Justice, NCJ 187285, FEDERAL Drug OfFEnders, 1999: With TRENDS $1984-1999$, at 8 (2001) (noting that $95 \%$ of those defendants charged with a drug offense pled guilty to at least one charge).

${ }^{145}$ Frank Bowman and Michael Heise noted an increased guilty plea rate in drug cases in the 1990s. Frank O. Bowman, III \& Michael Heise, Quiet Rebellion? Explaining Nearly a Decade of Declining Federal Drug Sentences, 86 IOwA L. REV. 1043, 1104-05 (2001) 
in the federal docket, the guilty plea rate for those crimes also came much closer to matching the plea rate for other federal crimes.

The odds of acquittal in narcotics cases also shifted over time. In 1950, federal drug cases produced an acquittal rate above the norm for that year: $3.3 \%$ of narcotics cases versus $2.4 \%$ of federal cases overall. Today, drug cases are less likely than the standard federal case to end with an acquittal: $0.6 \%$ for drug cases versus $0.9 \%$ overall for $2002 .{ }^{146}$

Plainly, something happened to federal drug crimes over the years. They became much more numerous, harder for defendants to win, and more likely to end with a guilty plea. ${ }^{147}$ The narcotics cases, like the liquor cases in earlier days, drew closer to the norm on guilty plea and acquittal rates possibly because of an increasing trial penalty. Perhaps the best we can do for now is to ascribe the phenomenal growth (one might even call it metastasizing) of drug cases to the shifting priorities of federal prosecutors and lawmakers.

The various types of crimes that influenced the mix of outcomes over the years are not limited to liquor and drug cases. In recent years, immigration and weapons cases have become salient, and in earlier eras, automobile theft cases had a significant presence. ${ }^{148}$ In each of these instances, the effect of the crime category was noteworthy but brief. Liquor cases dominated the federal scene, but only during the 1920s and early 1930s. Narcotics cases mattered not at all until the 1970 s, because there were so few of them until that time. Particu-

(showing that guilty plea rates in drug trafficking cases climbed steadily from $82 \%$ in 1992 to $94.2 \%$ in 1999 ).

${ }^{146}$ According to statistics from the AOUSC, the cases of 80 of the 2,400 narcotics defendants in 1950 ended in acquittals. Bureau of Justice Statistics, supra note 70. In 2002, 184 of 29,477 ended in acquittals. Id. Because successful motions to suppress evidence in drug cases often effectively end the cases by producing dismissals, dismissals as opposed to acquittals might become especially significant dispositions in drug cases.

${ }^{147}$ Various features of drug cases that signal their seriousness (such as type of drug, amount of drugs, or number of persons involved in the distribution) can only explain a small portion of the changes in acquittal and guilty plea rates. See Bowman \& Heise, supra note 145, at 1088, 1128 (stating that recent changes in the types of cases and defendants prosecuted correlate with prosecutor willingness to engage in plea bargaining practices); Frank O. Bowman, III \& Michael Heise, Quiet Rebellion II: An Empirical Analysis of Declining Federal Drug Sentences Including Data from the District Level, 87 IOWA L. REV. 477, 547 (2002) (discussing how "low-seriousness" drug crimes often receive extra sentence discounts beyond what the guidelines dictate).

${ }^{148}$ See Statistical Appendix, supra note 13, at app. 4. Immigration cases affected guilty plea and acquittal rates whenever prosecutors filed them in large numbers, but these cases appeared in high volume only during the 1940s, the early 1950 s, and from the mid-1990s to the present. Id. 
lar crimes always stay on the leading edge of changes in federal acquittals and guilty pleas, but the identity of such crimes changes often across the years.

\section{Sentence Severity and Trial Penalties in the 1990 s}

Sentencing law becomes relevant at the end of a criminal case, after conviction, but the effects of sentencing radiate back much earlier in the case to influence both guilty plea decisions and acquittal outcomes. Changes in federal sentencing practices during the 1980s and 1990s increased the certainty and size of the penalty for going to trial, and mightily influenced the guilty plea and acquittal rates during those times.

Given this clear logical connection between sentencing laws and guilty plea rates, it makes sense to concentrate on the Sentencing Reform Act of 1984 and the massive changes it wrought on federal criminal sentencing. The statute abolished parole, instituted the U.S. Sentencing Commission, and instructed the Commission to create federal sentencing guidelines that would direct the sentencing decisions of federal judges. ${ }^{149}$

The sentencing guidelines that took effect nationwide in 1989, together with some important mandatory sentencing laws that Congress passed between 1984 and 1989, dramatically shifted the sentencing outcomes in federal court. ${ }^{150}$ Sentences became far more severe: the use of probation withered, and prison terms stretched out. ${ }^{151}$ Given this new severity, some predicted that the sentencing guidelines would prompt a catastrophic increase in the trial rate, as defendants facing

\footnotetext{
${ }^{149}$ Sentencing Reform Act of 1984, Pub. L. No. 98-473, tit. II, ch. 2., 98 Stat. 1837, 1984; see generally Ronald F. Wright, Sentencers, Bureaucrats, and the Administrative Law Perspective on the Federal Sentencing Commission, 79 CAL. L. REV. 1, 7 (1991) (noting that a federal court must abide by the guidelines created by the Commission unless a departure is warranted).

${ }^{150}$ See Mistretta v. United States, 488 U.S. 361, 412 (1989) (affirming the constitutionality of the Sentencing Reform Act); Gary T. Lowenthal, Mandatory Sentencing Laws: Undermining the Effectiveness of Determinate Sentencing Reform, 81 CAL. L. REV. 61, 61 (1993) ("[D] eterminate sentencing schemes and mandatory enhanced sentences have largely displaced discretionary sentencing regimes operating within broad sentencing constraints.").

${ }^{151}$ U.S. Gen. Accounting Office, Sentencing Guidelines: Central QuesTIONS REMAIN UNANSWERED 19 tbl.1(1992) (showing that among the problems with the guidelines identified by judges, attorneys, and probation officers are dehumanization, severity, and lack of discretion).
} 
such severe sentences would have little to lose by going to trial. ${ }^{152}$ Those predictions turned out to be wrong, as guilty plea rates continued to climb after the guidelines took effect. ${ }^{15}$

Predictions about the effect of the sentencing guidelines on guilty plea rates initially focused on the wrong factor. The severity of sentences generally matters less in plea bargaining than the size of the discount that a defendant receives for pleading guilty. ${ }^{154}$ To the extent the plea discount is large and certain, guilty pleas will follow; when the plea discount is small and uncertain, more trials will occur. ${ }^{155}$

One key accomplishment of the federal sentencing guidelines was to make the plea discounts more certain. For example, defendants typically had to plead guilty to receive the two-level or three-level sen-

${ }^{152}$ See Terence Dunworth \& Charles D. Weisselberg, Felony Cases and the Federal Courts: The Guidelines Experience, 66 S. CAL. L. REV. 99, 151 (1992) (ascribing increased trial rates, especially for drug cases, to the implementation of the guidelines and the concomitant mandatory minimums and changes in prosecutorial policies); Gerald W. Heaney, The Reality of Guidelines Sentencing: No End to Disparity, 28 AM. Crim. L. REv. 161,184 (1991) ("[T] he sentencing data from the selected districts demonstrate that the guidelines have reduced the number of defendants pleading guilty even though the guidelines have increased the incentive to plead guilty and enhanced the penalty for going to trial."); cf. Reinganum, supra note 59, at 65 (2000) (stating that the game theory model suggests that the guidelines will increase average sentence length but not the guilty plea rate).

153 See U.S. SENTENCING COMM’N, The Federal Sentencing Guidelines: A Report on the Operation of the Guidelines System and Short-Term Impacts on Disparity in Sentencing, Use of Incarceration, and Prosecutorial Discretion and Plea Bargaining, 66-77(1991) (demonstrating "the lack of an effect associated with the guidelines on the number and proportion of guilty pleas among filed cases."). The two-year hiatus in guilty plea rate increase, from 1989 to 1990 , could be attributed to the uncertainty of the parties over how to apply the new rules. Several Department of Justice policies issued between 1989 and 1992 attempted to control the use of plea bargains by line prosecutors, and these policies might help explain the depressed rates of guilty pleas in the 1989-1991 period. See MILLER \& WRIGHT, supra note 41, at 1014-25 (discussing how even after the adoption of the sentencing guidelines, prosecutors continued to engage in charge, fact, and sentence bargains, but were restricted by Attorney General policies). This theory seems tenuous, as rates increased again in 1992, while those policies were still in effect.

${ }^{154}$ See Bibas, supra note 12, at 2504-07 (discussing the effect of discounts on plea bargaining); Leipold, supra note 71, at 158 (indicating the effect of probable trial outcome on bargaining strategy); Marc L. Miller, Domination E Dissatisfaction: Prosecutors as Sentencers, 56 STAN. L. REV. 1211, 1258 (2004) (stating that guilty plea rates will continue to rise if prosecutors have the habit of offering deals the defendant "cannot refuse").

${ }^{155}$ See Celesta A. Albonetti, Prosecutorial Discretion: The Effects of Uncertainty, 21 LAW \& SOC'Y REV. 291, 295 (1987) (hypothesizing that with increased uncertainty in obtaining a conviction comes a decrease in the chances of prosecution, which in turn decreases the number of guilty pleas); Anne M. Heinz \& Wayne A. Kerstetter, Pretrial Settlement Conference: Evaluation of a Reform in Plea Bargaining, 13 LAW \& SOC'Y REV. 349, 363-64 (1979) (stating that $60 \%$ of defendants interviewed said that the prospect of a more severe sentence after trial was an important factor in deciding to plead guilty). 
tence discount for "acceptance of responsibility;" 156 about $94 \%$ of the defendants who pled guilty received the discount while only $8 \%$ of the defendants who went to trial were given credit at sentencing for accepting responsibility. ${ }^{157}$ In a similar vein, prosecutors were highly unlikely to recommend a "substantial assistance" departure for defendants who insisted on a trial. ${ }^{158}$ Other portions of the guilty plea discount were delivered through "guideline factor bargains" (in which the parties agree to the applicability of certain adjustments up or down in the guideline calculations) and "fact bargains" (in which the parties stipulate to the presence of certain facts relevant to the sentence). ${ }^{159}$

These methods of guaranteeing a plea discount, especially when combined with the increased certainty that the judge (now subject to appellate review) would remain near the sentence range that the parties recommended, promoted more guilty pleas. It also appears likely that the size of the discount bulked up during the guideline years. ${ }^{160}$

${ }^{156}$ U.S. SENTENCING GuIDELInes MANuAL \$ 3E1.1 (2004) (setting forth the "Acceptance of Responsibility" guidelines); see also Michael M. O'Hear, Remorse, Cooperation, and "Acceptance of Responsibility": The Structure, Implementation, and Reform of Section $3 E 1.1$ of the Federal Sentencing Guidelines, 91 Nw. U. L. REv. 1507, 1513 (1997) (arguing that the commission sought to encourage guilty pleas without incurring the disadvantage of automatic sentence discounts, and found acceptance of responsibility discounts to be a good solution); Andrew J. Hosmanek, Beyond Remorse: True Acceptance of Responsibility and a Proposal for the Reform of Section 3E1.1 of the Federal Sentencing Guidelines 19-24 (Nov. 2004), available at http:// papers.ssrn.com/abstract=613687 (discussing what it means to "accept responsibility" and when this downward adjustment should be, and is most frequently, granted).

${ }^{157}$ More specifically, according to Sentencing Commission data for fiscal year $2001,6.1 \%$ of defendants pleading guilty or nolo contendere failed to receive a discount for acceptance of responsibility, while $92 \%$ of the defendants going to trial failed to receive such a discount. Bureau of Justice Statistics, supra note 70.

${ }^{158}$ See 18 U.S.C. $\$ 3553$ (e) (2000) (providing courts with limited authority to impose a sentence below the statutory minimum to reflect a defendant's substantial assistance in the investigation or prosecution of another defendant); U.S. SENTENCING GUIDELINES MANUAL $\$ 5 \mathrm{~K} 1.1$ (2004) (describing factors the court may consider when determining a substantial assistance departure). In fiscal year 2001, $17.7 \%$ of defendants who pled guilty also received a substantial assistance departure, while $1.7 \%$ of defendants who went to trial received such a departure sentence. The specific figures appear in the USSC SC01OUT database. See Bureau of Justice Statistics, supra note 70.

${ }_{159}$ See Stephen J. Schulhofer \& Ilene H. Nagel, Plea Negotiations Under the Federal Sentencing Guidelines: Guideline Circumvention and Its Dynamics in the Post-Mistretta Period, 91 Nw. U. L. REV. 1284, 1292-93 (1997) (discussing guideline factor bargains and fact bargaining and their use in circumventing the guidelines).

${ }^{160}$ The average prison sentence, in months, imposed in 2001 was 42.5 after a guilty or nolo plea, and 138.5 after trial. These calculations are derived from the USSC SC01OUT database. See Bureau of Justice Statistics, supra note 70. 
The federal guidelines changed more than the size and certainty of the trial penalty: they also changed who controls the penalty. Whereas the judge and the prosecutor once competed for control over the rewards for pleading guilty, the sentencing guidelines, operating in a high volume system, shifted more of this control away from the judge and toward the prosecutor. Defense attorneys grumble that prosecutors operating under the sentencing guidelines can make it virtually impossible to resist a guilty plea offer. ${ }^{161}$ Judges also observe frequently that the sentencing guidelines increased the relative strength of the prosecutors and upset the balance of power in the system. ${ }^{162}$ More interestingly, federal judges note that the price of going to trial has become so high that it undermines confidence in the accuracy of guilty pleas. ${ }^{163}$ Academics and journalists make the same observation in passing. ${ }^{164}$

${ }^{161}$ See Margareth Etienne, The Declining Utility of the Right to Counsel in Federal Criminal Courts: An Empirical Study on the Diminished Role of Defense Attorney Advocacy Under the Sentencing Guidelines, 92 CAL. L. REV. 425, 482-83 (2004) (explaining that some federal defense attorneys have recharacterized the central focus of their jobs as counseling defendants on sentencing consequences, rather than resisting charge and risking loss of credit for cooperation); Laurie P. Cohen \& Gary Fields, Reasonable Doubts: How Unproven Allegations Can Lengthen Time in Prison, WALL ST. J., Sept. 20, 2004, at A1 (quoting a defense attorney as saying, "Probation officers go to town and kill defendants who go to trial .... If you go to trial and lose, you get the book thrown at youwithout having a jury consider all the facts of your case. It dissuades you from your constitutional right to go to trial").

${ }^{162}$ See Molly Treadway Johnson \& Scott A. Gilbert, The U.S. SEntencing GUIDELINES: RESUlTS OF THE FEDERAL JUDICIAL CENTER's 1996 SURVEY 6 (1997), available at http://www.fjc.gov/public/pdf.nsf/lookup/gssurvey.pdf (reporting that over $86 \%$ of district judges and chief probation officers either somewhat or strongly agreed with the statement, "The Sentencing Guidelines give too much discretion to prosecutors"); KATE STITH \& JOSE CABRANES, FEAR OF Judging: SENTENCing GuidELines in THE FEDERAL COURTS 195 n.12 (1998) (listing several articles, essays, and letters written by judges that criticize the guidelines).

${ }^{163}$ See United States v. Green, 346 F. Supp. 2d 259, 288-89 (D. Mass. 2004) (ruling that the sentencing guidelines are unconstitutional partly because of the prosecutor power to penalize going to trial).

${ }^{164}$ See Lowenthal, supra note 150 , at 78 (stating that the threat of filing a charge with a mandatory minimum sentence "pressure[s] defendants, who otherwise might test the state's evidence, into accepting guilty pleas"); Robert G. Morvillo \& Barry A. Bohrer, Checking the Balance: Prosecutorial Power in an Age of Expansive Legislation, 32 AM. CRIM. L. REV. 137, 137 (1995) (explaining that guidelines give prosecutors "greater leverage to virtually compel plea bargaining, force cooperation, and in essence determine the length of sentences"); William J. Stuntz, Plea Bargaining and Criminal Law's Disappearing Shadow, 117 HARV. L. REV. 2548, 2551-54 (2004) (discussing how the costs of going to trial affect plea bargaining); Mary Pat Flaherty \& Joan Biskupic, Prosecutors Can Stack the Deck, WASH. POST, Oct. 7, 1996, at A1 (describing several cases in which the maximum sentence imposed by the federal sentencing guidelines influenced a defendant's decision to plea bargain); Marc Miller \& Ronald Wright, Prosecutor Rex, 
Recent developments in federal sentencing law accelerated the trend toward concentrating the control over the trial penalty in the hands of the prosecutor. In 2003, Congress amended the sentencing statutes (in the so-called "Feeney Amendment") to restrict the power of judges to depart from the presumptive guideline sentence, except in cases where the prosecutor recommends a discount. ${ }^{165}$ The same law gave prosecutors absolute control over one part of the sentence discount for acceptance of responsibility. ${ }^{166}$

In 2005, another profound change in federal sentencing shifted the control back toward a more even balance between the prosecutor and the judge. The Supreme Court ruled in United States $v$. Booker that a sentencing judge cannot increase the presumptive guideline range applicable to a defendant unless a jury finds the facts needed to authorize the increased sentence. ${ }^{167}$ Yet in a remarkable application of severability doctrine, the Court also declared that the remedy for this unconstitutional application of the guidelines in some cases was to treat the guidelines as non-binding in all cases. Because the guidelines are now non-binding, the plea discounts that prosecutors offer to defendants are less certain than before. The judge might or might not follow the recommendation for a guideline sentence, leaving defendants less certain about whether a given judge will apply the sentence discounts as expected. ${ }^{168}$

The federal guidelines were not the only source of changes in sentencing law that affected the price defendants paid for going to trial.

PHILA. INQUIRER, Dec. 19, 2003, at A39 (suggesting that large differences between sentences from trials and sentences from plea bargains can unduly sway defendants towards plea bargains).

${ }^{165}$ See Prosecutorial Remedies and Tools Against the Exploitation of Children Today (PROTECT) Act of 2003, Pub. L. No. 108-21, § 401, 117 Stat. 650, 667-76 (detailing when a judge may impose a sentence below the guideline standard). For commentary on the effects of the PROTECT Act, see Miller, supra note 154, at 1227, which notes in particular how the PROTECT Act induced changes in the sentencing guidelines regime beyond the original congressional intent); also helpful is Stephanos Bibas, The Feeney Amendment and the Continuing Rise of Prosecutorial Power to Plea Bargain, 94 J. CRIM. L. \& CRIMINOlOGY 295, 297-303 (2004), which predicts that the Feeney Amendment will lead to decreased judicial discretion and increased prosecutorial power).

${ }^{166}$ PROTECT Act $§ 401,117$ Stat. at 671-72; see generally Margareth Etienne, Acceptance of Responsibility and Plea Bargaining Under the Feeney Amendment, 16 FED. SENT'G REP. 109 (2003) (outlining increased options for plea bargaining in light of the new legislation).

167 S. Ct. 738 (2005).

${ }^{168}$ The precise contours of this uncertainty will depend on the type of appellate review that develops under the "reasonableness" standard of review that the Booker court created. For that standard, see $i d$. at 765 . 
The guidelines took effect in 1989, but the severity of federal sentences increased for many years before that, just as guilty plea increases and acquittal decreases pre-dated the guidelines. ${ }^{169}$ Over the long haul, as the severity of the sentencing options that prosecutors could utilize increased, larger plea discounts became possible.

While acknowledging the more long-term forces at work in the law of federal sentencing, we must keep the guidelines at the center of the story. Recall from Figure 2 that acquittals in federal court, while they declined throughout the 1980s, began their steepest decline after 1989. ${ }^{170}$ The greatest imbalances between acquittals and other outcomes (including guilty pleas, trial convictions, and dismissals) all appeared in the $1990 \mathrm{~s}$. In short, the federal sentencing guidelines were a driving force in the disturbing disappearance of acquittals from the system.

\section{E. Prosecutor Power as the Leading Acquittal Culprit}

As we have seen, several different features of federal criminal practice could have altered guilty plea and acquittal rates over the decades. But it is one thing to know the possible culprits, and another thing to know which were the most important and how they interacted. Furthermore, our list of possible causes for guilty pleas and acquittals is only a partial one.

How might we estimate which of the many likely causes were most important? One clue comes from longevity. The effects of particular types of crimes (especially narcotics crimes) and procedural complexities (such as the presence of defense counsel and the expansion of pretrial release) were concentrated in fairly small time periods. The effect of prosecutor and judge caseloads, however, worked across many decades. For that reason, caseloads were probably more important than crime type or procedural complexity.

Statistical techniques also allow us to see the relative strength of several causes that contribute to a single effect. A standard statistical

169 Cf. Bureau of Justice Statistics, U.S. DeP'T OF Justice, supra note 36, at 12 (indicating an increase in prison sentences prior to 1989). For indications that guilty pleas increased and acquittals decreased before 1989, see supra Figures 1 and 2 and the Statistical Appendix, supra note 13, at app. 1.

${ }^{170}$ One aspect of the federal sentencing guidelines changed the value of partial acquittals: relevant conduct provisions made it more likely that even acquitted conduct would still increase the defendant's sentence. See Rachel E. Barkow, Recharging the Jury: The Criminal Jury's Constitutional Role in an Era of Mandatory Sentencing, 152 U. PA. L. REV. 33, 93-94 (2003) (describing the limited value of partial acquittals under the sentencing guidelines). 
tool of social scientists known as multiple regression analysis tracks the effects of several different factors on an outcome and estimates the weight of each factor, while holding constant the influence of the others. ${ }^{171}$ Treating the yearly rates of guilty pleas and acquittals as the two "effects" to be explained, multiple regression analyses for the period from 1945 to 2002 (set out in the Appendix) confirm that the number of prosecutors was the strongest among the potential causes. $^{172}$

The significant influences on the guilty plea rate in a given year included the number of federal prosecutors, the number of district court judges, and the percentage of immigration crimes prosecuted that year. For acquittal rates, the significant variables included those same three factors plus the combined civil and criminal caseload on judges.

Among all the significant variables, prosecutor resources showed the largest effects. A larger number of prosecutors tended to send acquittals down and guilty pleas up. Meanwhile, the number of judges had just the opposite effects: a larger judiciary produced higher acquittal rates and lower guilty plea rates. Judges with larger combined caseloads had lower acquittal rates.

Why would more prosecutors-presumably with more time to devote to the available cases-tend to produce more guilty pleas and fewer acquittals (even after controlling for the number and complexity of criminal cases terminated in a given year)? This may be a sign that when the Department of Justice hired new prosecutors, they added to the quantity more than the quality of cases.

Another relationship among the possible causes of these outcomes deserves close attention as well: the positive and negative signs for the judge variables point in the opposite direction from the signs for the prosecutor variables. Every prosecutor positive finds a matching judicial negative, and vice versa. This polarity-additional judges and prosecutors had opposite effects on both the acquittal rate and

${ }^{171}$ For a more complete description of regression analysis, see MiCHAEL O. FinKELSTEIN \& BRUCE LEVIN, STATISTICS FOR LAWYERS 323-29 (1990). The two regressions presented in the Appendix to this Article are weighted least squares regressions because the number of cases terminated in each year varied, making the percentages for some years more reliable than others.

${ }^{172}$ There is some risk of multi-collinearity in the use of annual data. For that reason, the regression in the Appendix explores a minimal number of variables and its results should be interpreted cautiously. 
guilty plea rate-speaks volumes about the accuracy hypothesis. ${ }^{173}$ If additional prosecutors were presenting stronger and more convincing cases at trial, the addition of new judges to preside over these supposedly more reliable cases should not cause an increase in the acquittal rate. Instead, the extra judges would make it possible to achieve more trial convictions in these higher quality cases.

Granted, it is conceivable that extra judges made trials less accurate, perhaps by giving unwarranted consideration to defense motions to exclude reliable but improperly obtained evidence. ${ }^{174}$ But this explanation of the statistical polarity between prosecutors and judges requires us to believe that judges acted against type for many decades. The aspiration of the trial judge in an adversary system is to promote justice through accurate factual findings.

Statistical analysis indicating judges and prosecutors working at cross purposes, and prosecutors exerting the larger influence, does not speak well for the overall accuracy of the system. In a world where additional prosecutors and judges have opposite effects, it seems more likely that new prosecutors add new (probably weaker) cases to the system and keep the guilty plea rate high by increasing the size or certainty of the guilty plea discount.

The interaction of the limited number of factors explored so far tells us that guilty plea rates move higher and acquittal rates move lower when prosecutors have the time to push them there. The displaced acquittal is a marker of prosecutorial opportunity and power.

The factors discussed so far do not exhaust the possibilities. For one thing, we have reviewed potential causes internal to the criminal justice system (such as the legal rules and resources available to the parties), but no factors external to the system. For instance, changing crime rates or the type of crime politics at work in a particular era might give prosecutors different attitudes about guilty pleas. ${ }^{175}$ Judges under different social conditions might prove more or less willing to reward defendants for pleading guilty.

Many social conditions could affect the pool of potential jurors, making them less inclined to acquit. Public attitudes toward crime

${ }^{173}$ Cf. FISHER, supra note 22, at 116-24 (arguing that caseload pressures on judges made them more amenable to plea bargaining).

${ }^{174}$ See PIZZI, supra note 53, at 69-72, 222-23 (1999) (contending that a defendant's ability to suppress essential evidence through procedure is symptomatic of a weak trial system).

${ }^{175}$ See generally TED GeST, CRIME \& POLITICS (2001) (describing the interaction between policymaking and crime control); STUART ScheIngOLD, THE POLITICS OF STREET CRIME (1990) (discussing how politics can affect the criminal process). 
changed over the years, and very well could have affected the pattern of outcomes in federal court. Over the last few decades in particular, there has been a hardening of public attitudes about crime. ${ }^{176}$ Such a shift of attitudes might have encouraged guilty pleas and made acquittals more difficult to achieve.

Some additional factors "internal" to criminal justice, such as the role of defense counsel or particular types of sentence discounts, also have received only passing attention so far. Surely, then, our brief look at the federal criminal docket over the decades could benefit from a closer look. Part IV takes a more detailed tour of the possible causes for guilty plea and acquittal rates in the federal districts during the remarkable recent period from 1994 to 2002.

\section{LEGAL ENVIRONMENTS HOSTILE TO INNOCENCE}

The federal criminal system divides into ninety-four distinct districts, each sharing some common features. Every district implements the same federal statutes defining crimes, adjudication procedures, and sentences, and each follows the same policies set by "Main Justice" in Washington, D.C., for the entire Department. ${ }^{177}$ The U.S. Attorney's Offices also operate under centralized budgetary constraints from Congress, money that the legislature sometimes uses to encourage particular priorities for investigation and prosecution. ${ }^{178}$

But each of the ninety-four federal districts also has much autonomy, and each produces its own distinctive brand of federal justice. The United States Attorney for each district makes all the hiring deci-

${ }^{176}$ See Austin Sarat \& Neil Vidmar, Public Opinion, the Death Penalty, and the Eighth Amendment: Testing the Marshall Hypothesis, 1976 WIS. L. REV. 171, 175-76 (finding dramatic growth in public support for capital punishment from 1966 to 1976); Tom R. Tyler \& Robert J. Boeckmann, Three Strikes and You Are Out, But Why? The Psychology of Public Support for Punishing Rule Breakers, 31 LAW \& SOC'Y REV. 237, 257 (1997) (stating that public support of punishment has increased over the last forty to fifty years); $c f$. Neil Vidmar, Retribution and Revenge, in HANDBOOK OF JUSTICE RESEARCH IN LAW 31, 41-57 (Joseph Sanders \& V. Lee Hamilton eds., 2001) (exploring the sociological and psychological functions that punishment serves).

${ }^{177}$ A few federal districts must process a distinctive set of crimes because of the presence of Indian reservations or large government installations such as military bases. See Assimilative Crimes Act, 18 U.S.C. $\$ 13$ (1996) (providing instruction for the sentencing of crimes, not otherwise punishable, that are committed within federal jurisdictions).

${ }^{178}$ See generally Daniel C. Richman, Federal Criminal Law, Congressional Delegation, and Enforcement Discretion, 46 UCLA L. REV. 757, $793-99$ (1999) (describing how Congress's budgetary powers can influence criminal enforcement decision making). For an example in the arena of weapons crimes, see Daniel C. Richman, "Project Exile" and the Allocation of Federal Law Enforcement Authority, 43 ARIZ. L. REV. 369, 392-96 (2001). 
sions for local attorneys and support staff, and allocates resources to respond to the priorities of the district. The prosecutors in each district interact with a defense bar with a distinctive local character, ${ }^{179}$ and they encounter trial judges with individual priorities and habits, along with the life tenure to protect that individuality. ${ }^{180}$

This setting creates the conditions for a natural experiment. ${ }^{181}$ While holding constant the basic legal framework from district to district, the environment changes as prosecutorial policies and habits of working groups shift from place to place. Tracking these environmental changes allows us to see which of them contribute to high guilty plea and low acquittal rates. ${ }^{182}$

This Part explores some key characteristics of the ninety-four federal districts between 1994 and 2002. Although the time frame is much shorter than that in our previous inquiry, it covers most of the era of the sentencing guidelines-an era that, as we have seen, produced levels of guilty pleas and acquittals extreme enough to sound a clear warning. The inquiry now becomes narrower but deeper. ${ }^{183}$

Patterns of outcomes in the districts reveal some of the particular sentencing laws that have contributed most clearly to the drop in acquittals over the last decade. Departures from the sentencing guidelines based on a defendant's "substantial assistance" made a measurable difference. The same was true of the three-level "super acceptance of responsibility" discount. Where these methods-largely

${ }^{179}$ Some attorneys are privately retained, some are in private practice appointed by the court under the Criminal Justice Act ("CJA panel attorneys"), and others are staff attorneys for the Federal Public Defender.

${ }^{180}$ See U.S. CONST. art. III, $\S 1$ ("The Judges, both of the supreme and inferior Courts, shall hold their Offices during good Behavior ....").

${ }^{181}$ Others have taken advantage of this natural experiment opportunity in exploring other questions relating to federal criminal justice. See Bowman \& Heise, Quiet Rebellion, supra note 145, at 1126 (investigating factors that influence the length of federal drug sentences); Bowman \& Heise, Quiet Rebellion II, supra note 147, at 554-58 (investigating further the factors that influence the length of federal drug sentences); Michael Edmund O'Neill, When Prosecutors Don't: Trends in Federal Prosecutorial Declinations, 79 Notre DAME L. Rev. 221, 249-71 (2004) (exploring prosecutorial decisions to refuse to pursue indictment).

${ }^{182}$ Cf. J. Fred Springer, Burglary and Robbery Plea Bargaining in California: An Organizational Perspective, 8 JUST. SYS. J. 157, 182-84 (1983) (conducting a three-county study that isolated environmental factors contributing to different guilty plea practices).

${ }^{183}$ The shorter study period also makes it practical to consider a longer list of potential causes based on consistent data sources. Unless otherwise indicated, the district-level data in this Part are compiled from case-level data assembled by the AOUSC or the U.S. Sentencing Commission (the AOUSC ADJOUT and USSC SCOUT databases). See Bureau of Justice Statistics, supra note 70. Many of the variables studied here are not available in consistent and convenient formats prior to fiscal year 1994. 
controlled by prosecutors-were used most commonly, they contributed to an environment in the district that convinced defendants to plead guilty and to opt out of trials that might have ended in acquittals. More generally, the prosecutor's willingness to decrease the offense level under the guidelines resulted in more guilty pleas and fewer acquittals.

Identifying the effects of sentencing devices such as these points the way to a more healthy sentencing law down the road. Sentencing discounts resting solely in the hands of prosecutors, such as substantial assistance departures, create the greatest threat of trial distortion. The size of the trial penalty can remain reasonably small and relatively uncertain-as it should be-only if judges retain some authority to disagree with prosecutors about proposed discounts. Rules that designate judges as legitimate counterweights to prosecutors create a separation of powers for sentencing, a state of affairs that holds the best hope for reliable and accurate criminal justice.

\section{A. Environmental Audits}

The two separate regression analyses constructed here use two different "dependent variables" (the phenomena that are caused by the "independent variables"). ${ }^{184}$ The percentage of guilty pleas and the percentage of acquittals in a particular district for a given year occupy the center of attention, because a key indicator of trial distortion happens when guilty plea rates rise while acquittal rates fall. ${ }^{185}$

The independent variables (that is, the potential causes of change) fall under several different headings. A first group of variables attempts to measure the workload that the key actors must carry. They track the number of cases that each prosecutor and judge han-

\footnotetext{
${ }^{184}$ Because the dependent variables for the two studies are expressed as percentages, I use a weighted least squares regression to account for the different volume of cases in each district. The weighting variable, the number of defendants in each district for each fiscal year whose cases were terminated, is found in the Judicial Business Annual Report of the AOUSC, at Table D-7. See AOUSC Judicial Bus. AnN. ReP. tbl.D7 (1994-1997); AOUSC JUdICIAL Bus. ANN. REP. tbl.D-7 (1998-2002) available at http://www.uscourts.gov/judbususc.judbus.html.

${ }^{185}$ I omitted the Middle District of Georgia for every year in the study because of its extremely high number of acquittals, which is a product of the large number of traffic offenses prosecuted as federal misdemeanors in that district. In a unique arrangement, the federal courts process all traffic violations that occur on two large military bases in the district. Leipold, supra note 71, at 192. Data was often unavailable for at least one variable in Puerto Rico, the Virgin Islands, Guam, and the Northern Mariana Islands; because the weighted least squares regression in Table 2 uses a crosswise delete method, these districts are not included in the study.
} 
dled in each district for each year. ${ }^{186}$ The average number of days devoted to each criminal trial also could affect the workload of the actors and the willingness of the parties to go to trial. ${ }^{187}$ Perhaps the busy prosecutor with a heavier caseload is less anxious to take a case to trial (particularly if the average trial lasts many days) and thus will be more cooperative in plea negotiations or will increase the discount for pleading guilty. ${ }^{188}$ Those steeper discounts could convince more defendants to plead guilty, including a number who otherwise might have been acquitted.

A second group of variables estimates the influence of the leadership within each prosecutor's office. One variable shows the years in office of each U.S. Attorney, and another the political party of the President who appointed each U.S. Attorney. ${ }^{189}$ After the lead prosecutor in a district takes office and enacts new office practices, attorneys in the district should become more certain as to how various types of cases will be handled, and the number of guilty pleas should increase.

A third set of variables tracks various resources and characteristics of the defendant. The average number of "criminal history points" of

${ }^{186}$ The AOUSC calculates a "weighted" criminal caseload per judge for each district in each fiscal year, appearing in its Judicial Business Annual Report, Table X-1A. See AOUSC JUdicial BuS. ANN. REP. 1994-2002, supra note 184, at tbl.X-1A. The prosecutor workload is necessarily a more crude figure, obtained by dividing the number of defendants whose cases were terminated in the district by the number of AUSAs working in the district that year.

${ }^{187}$ Figures that form the basis for this average in each district for each fiscal year appear in the Judicial Business Annual Report, Table T-2. See id. at tbl.T-2. For details on the calculation of this figure, see the Statistical Appendix, supra note 13, at app.3.

${ }^{188}$ See Bowman \& Heise, Quiet Rebellion II, supra note 147, at 552 (concluding that prosecutor workload correlated with sentence reductions in drug cases). Richard Boylan and Cheryl Long explored drug cases from 1993 to 1996 and concluded that prosecutors from the largest and smallest offices are the ones most likely to go to trial, while average-size offices are more likely to produce guilty pleas. They postulate that prosecutors in settings where monitoring is difficult will be more likely to go to trial to develop their "human capital" in trial skills. See Richard T. Boylan \& Cheryl X. Long, Size, Monitoring, and Plea Rate: An Examination of United States Attorneys 1 (July 10, 2000) (unpublished manuscript), http://fmwww.bc.edu/RePEc/es2000/0089.pdf (studying the effectiveness of monitoring and its effect on U.S. Attorney performance by examining plea rates).

${ }^{189}$ In calculating the tenure of U.S. Attorneys, the year of appointment was designated as a 0 , and one point added for each additional year in office. U.S. Attorneys appointed by Republican Presidents were coded as 1, and those by Democratic Presidents as 0. Information about the appointment of U.S. Attorneys was located on http://thomas.loc.gov. See Richard T. Boylan, Salaries, Turnover, and Performance in the Federal Criminal Justice System, 47 J.L. \& ECON. 75, 87 (2004) (demonstrating the use of U.S. Attorney tenure as an independent variable and showing that longer tenure increased the guilty plea rate). 
defendants sentenced in a district might indicate the amount of experience those defendants have with the criminal justice system, and could affect the willingness of the judge and prosecutor to discount a sentence. ${ }^{190}$ Federal prosecutors have relatively little control over the criminal history points that figure into a defendant's sentence. ${ }^{191}$ As a result, this variable presents a test of the accuracy hypothesis: a district with more serious, high-priority repeat criminals to prosecute ought to produce fewer acquittals. Increasingly accurate prosecutors would emphasize quality over quantity, and their district would contribute more than its share to a declining acquittal rate.

Because defendants who are detained until the date of trial are considered more likely to plead guilty, ${ }^{192}$ another variable notes the percentage of defendants in a district who are released before trial. ${ }^{193}$ The percentage of defendants in a district who are Hispanic, black, or female also go into the model. ${ }^{194}$

Another defendant resource to consider is the type of counsel working on the case. ${ }^{195}$ An unusual number of defendants in the federal system retain private counsel, and in many settings it might be

${ }^{190}$ The average criminal history points for defendants sentenced in each district for each fiscal year came from databases of the U.S. Sentencing Commission, using the TOTCHPTS variable. See Bureau of Justice Statistics, supra note 70.

${ }^{191}$ The prosecutor might make some adjustments at the margins, but prior record has more or less the same effect regardless of any negotiated agreements. There are some limited exceptions to this observation: for example, prosecutors do have more practical control on the use of "armed career criminal" and "career criminal" enhancements. See U.S. SENTENCING Guidelines MANUAL § 4B1.1, .4 (2004) (outlining sentencing ranges under these enhancements). These enhancements apply in relatively few cases. As we will see, the usage of career criminal enhancements in a district had no significant effect on guilty pleas or acquittals. See Table 3. The percent of career criminal enhancements applied in each district during each fiscal year was calculated based on the Sentencing Commission database, CAROFFAP variable. See Bureau of Justice Statistics, supra note 70.

${ }^{192}$ See Compelling Appearance in Court, supra note 132, at 1031; supra note 129 and accompanying text.

${ }^{193}$ See Bibas, supra note 12, at 2491-93 (discussing the impact of bail and pretrial detention on guilty pleas); see also 18 U.S.C. $\$ 3146$ (b) (2000); Salerno, supra note 134; supra, notes 131, 134 and accompanying text.

${ }^{194}$ Other scholars have noted a racial differential in the decision to plead guilty. See Celesta A. Albonetti, Race and the Probability of Pleading Guilty, $6 \mathrm{~J}$. QUANTITATIVE CRIMINOLOGY 315, 332 (1990) (finding that black defendants are, in some circumstances, less likely to plead guilty).

${ }^{195}$ The percentage of cases in each district defended by Criminal Justice Act panel attorneys, Federal Public Defender attorneys, or private attorneys (along with the percentage of cases involving waiver of attorney) can be found in the AOUSC ADJOUT database, using the FLCOUNSL variable. See Bureau of Justice Statistics, supra note 70. 
reasonable to expect stronger results from private attorneys. ${ }^{196}$ However, the appointed attorneys in the federal system are exceptionally well-trained and well-funded, so it is just as plausible that the type of counsel used in a federal district does not affect that district's guilty plea or acquittal rates.

The next group of variables explores the types of crimes charged in each district. These include the percentage of drug crimes, violent crimes, theft and fraud crimes, weapon crimes, and immigration crimes terminated annually in each district. ${ }^{197}$ As an overall estimate of the seriousness of the crimes charged, one variable calculates the average "offense level" under the federal sentencing guidelines for defendants sentenced in the district. ${ }^{198}$

In contrast to the variable for criminal history points, the offense level tells us more about the prosecutor's discretionary choices than about the raw material that the docket presents in a district. When it comes to the offense level to be assigned, the federal prosecutor has enormous discretion. ${ }^{199}$ If the average offense level in a district affects

${ }^{196}$ Privately retained attorneys are generally believed to be more likely to go to trial and to obtain acquittals. See COMm. REPORT ON POVERTY, supra note 125, at 29 (citing statistics from various districts showing that "pleas of guilty are entered much more frequently by defendants with assigned counsel than those represented by private counsel"); William J. Stuntz, The Uneasy Relationship Between Criminal Procedure and Criminal Justice, 107 YALE L.J. 1, 35 \& nn.123-24 (1997) (pointing to studies that show that defendants with appointed counsel are more successful).

${ }^{197}$ The types of crimes terminated in each district for each fiscal year are available in the AOUSC ADJOUT database, using the TIGRON variable, which classifies all crimes according to a six-variable classification system of the Bureau of Justice Statistics. See Bureau of Justice Statistics, supra note 70.

The U.S. Sentencing Commission, in its 1995 Annual Report, hypothesized that guilty pleas were increasing because of an increase in immigration and fraud cases. See 1995 U.S. SENTENCING COMMISSION ANNUAL REPORT 51, available at http:// www.ussc.gov/ANNRPT/1995/ch5_95.pdf (identifying lower trial rates for these types of cases as contributing to the overall reduction in total trial rates and subsequent increase in the national plea rate). But George Fisher points out that the increased plea rates in drug cases over time is a better explanation. FISHER, supra note 22, at 344 n.77. Sara Beale has noted that guilty pleas for gun cases are increasing in number as the severity of sentences imposed for those crimes increases. See Sara Sun Beale, The Unintended Consequences of Enhancing Gun Penalties: Shooting Down the Commerce Clause and Arming Federal Prosecutors, 51 DUKE L.J. 1641, 1677 (showing prosecutors' inclination to use enhanced penalties as a "bargaining chip").

${ }^{198}$ The average offense level for each district in each fiscal year was calculated based on the database from the U.S. Sentencing Commission, using the XFOLSOR variable. See Bureau of Justice Statistics, supra note 70.

${ }^{199}$ Cf. David Yellen, Probation Officers Look at Plea Bargaining, and Do Not Like What They See, 8 FED. SENT'G REP. 339, 339 (1996) (reporting that about $40 \%$ of probation officers believe that guideline calculations set forth in plea agreements in a majority of cases are not supported by offense facts). 
the guilty plea or acquittal rates, that should reflect both the raw materials available to the prosecutors (giving us some reason to credit the accuracy hypothesis) and the negotiating power of prosecutors (giving us reason to believe the trial distortion theory).

More clear-cut tests for the trial distortion theory come from variables that more directly measure the perceived guilty plea discount that defendants encounter as they decide whether to proceed with trial. ${ }^{200}$ These address some of the most well-known methods that prosecutors have to reward cooperative defendants, including sentencing departures for those who provide "substantial assistance" to the government, ${ }^{201}$ and the enhanced three-point discount for defendants who fully accept responsibility for their crimes. ${ }^{202}$ The rate of judicial downward departures from the sentencing guidelines could also reveal efforts to reward defendants for pleading guilty. ${ }^{203}$

Two other blunt measures of the trial penalty try to capture the differential between the sentence after trial and the sentence after a guilty plea: one variable looks to the additional proportion of prison

200 Another potential measure of the prosecutor's power to create a guilty plea discount is the percentage of charges filed under statutes carrying mandatory minimum sentences, under such statutes as 21 U.S.C. $\$ 841$ (a) (1), (b) (1) (A), (B) (2000) (narcotics amounts); 21 U.S.C. $§ 843$ (b) (2000) (telephone count); 18 U.S.C. $§ 924$ (c) (2000) (use of firearm). However, because the discounting effect of mandatory minimum charges can be achieved either by filing the charges and dismissing them later, or by threatening to file the charges, this model does not track mandatory minimum charges filed.

${ }^{201}$ U.S. Sentencing Guidelines Manual $§ 5 \mathrm{~K} 1.1$ (2004). The percentage of cases in each district receiving the substantial assistance departure is available in the Annual Sourcebook of Federal Sentencing Statistics of the U.S. Sentencing Commission (for 1996-2002), available at www.ussc.gov/annrpts.htm, tbl.30, and in the Annual Report of the Commission (for 1995), available at www.ussc.gov/annrpts.htm.

${ }^{202}$ During the period 1994-2002, judges retained final authority over the rewarding of the three-point AR discount, but they relied heavily on prosecutors to determine whether the plea of guilty arrived early enough to save the necessary resources. The percentage of cases in each district for each fiscal year receiving a three-point discount for AR is calculated based on the USSC SCOUT database, using the ACCTRESP variable. See Bureau of Justice Statistics, supra note 70.

${ }^{203}$ The percentage of cases receiving a judicial downward departure in each district is available from the Annual Sourcebook of Federal Sentencing Statistics and the Annual Report of the Sentencing Commission. Other studies have treated departure sentences as dependent variables. See Jeffrey T. Ulmer \& John H. Kramer, Court Communities Under Sentencing Guidelines: Dilemmas of Formal Rationality and Sentencing Disparity, 34 CRIMINOLOGY 383, 385-86, 402-04 (1996) (exploring downward departures in three Pennsylvania counties and finding that formal rational factors interact with extralegal criteria deemed relevant by local court actors, and that legally-sanctioned sentencing criteria are intertwined with defendants' race and gender and exercise of trial rights). 
sentences imposed when defendants go to trial, while the other measures the longer duration of prison sentences imposed after trial. ${ }^{204}$

Finally, several variables estimate the influence of different circuit courts on the guilty plea and acquittal rates, after controlling for the other case characteristics described above. ${ }^{205}$ Differences among the circuits might reflect distinctive legal rules imposed by the appellate courts, or they could capture regional differences in courtroom practices and cultural differences in regions of the country that could translate into different acquittal or guilty plea rates.

The results of the two regression analyses-one for guilty plea rates and one for acquittal rates-appear in Table 3.

${ }^{204}$ The differential for each district between the sentencing result after trial and after a guilty plea is calculated based on the AOUSC ADJOUT database. The figures are available through a cross-tabulation of the DISPOSIT variable and the TOTPRISN variable (for duration) or the SENTENCE variable (for prison percentage). See Bureau of Justice Statistics, supra note 70.

Because the cases going to trial may not be randomly selected, it is possible that any difference in the sentences attached to the cases in the guilty plea and trial pools is not actually a discount for pleading guilty. It may instead show that one or the other of the pools involves more serious crimes. See FISHER, supra note 23, at 345 n.85 (investigating severity of the crime as a sentencing differential); Richard S. Frase, Implementing Commission-Based Sentencing Guidelines: The Lessons of the First Ten Years in Minnesota, 2 Cornell J.L. \& PUB. POL'y 279, 287-337 (1993) (analyzing the duration of the sentence as a function of offense severity); Terence D. Miethe \& Charles A. Moore, Socioeconomic Disparities Under Determinate Sentencing Systems: A Comparison of Preguideline and Postguideline Practices in Minnesota, 23 CRIMINOLOGY 337, 337-63 (1985) (showing that even under determinate sentencing schemes, there will be differences in sentence duration that can be attributed to the severity of the offense). Note that offense level, prior criminal record, and several other case features are controlled in this study.

${ }^{205}$ The circuits were coded as categorical variables, and the regressions presented in Table 2 used the Fifth Circuit as the reference category. Because the circuits are categorical variables, the standardized coefficients for the circuits only allow comparisons between the size of impact relative to other circuits; no comparisons with other factors are possible. 
Table 3: Weighted Regression of Annual District-Level Guilty Plea and Acquittal Rates, on Factors Related to Case Processing and Prosecutorial Discretion, Federal Criminal Cases, 1994-2002

\begin{tabular}{|c|c|c|c|c|c|c|}
\hline & \multicolumn{3}{|c|}{ Guilty Plea \% } & \multicolumn{3}{|l|}{ Acquittal \% } \\
\hline & Coefficient & Standardized & $\mathbf{t}$ & Coefficient & Standardized & $\mathbf{t}$ \\
\hline \multicolumn{7}{|l|}{ Caseload Factors: } \\
\hline Prosecutor & $8.735 \mathrm{E}-05$ & 0.031 & 0.980 & $-5.16 \mathrm{E}-06$ & -0.008 & -0.186 \\
\hline \multicolumn{7}{|l|}{ Criminal Caseload } \\
\hline Judge & $-4.25 \mathrm{E}-05$ & $-0.165^{* *}$ & -3.300 & $3.203 \mathrm{E}-06$ & 0.051 & 0.800 \\
\hline \multicolumn{7}{|l|}{ Criminal Caseload } \\
\hline Average Trial Days & $-4.75 \mathrm{E}-03$ & $-0.139^{* *}$ & -4.030 & $1.540 \mathrm{E}-04$ & 0.019 & 0.421 \\
\hline \multicolumn{7}{|c|}{ Prosecutor Office Leadership Factors: } \\
\hline U.S. Attorney & $3.601 \mathrm{E}-04$ & 0.020 & 0.829 & $-1.44 \mathrm{E}-04$ & -0.032 & -1.070 \\
\hline \multicolumn{7}{|l|}{ Tenure } \\
\hline U.S. Attorney & $3.974 \mathrm{E}-03$ & 0.038 & 1.469 & $-1.31 \mathrm{E}-03$ & -0.052 & -1.564 \\
\hline \multicolumn{7}{|l|}{ Political Party } \\
\hline \multicolumn{7}{|l|}{ Defendant Factors: } \\
\hline Black \% & $4.466 \mathrm{E}-02$ & $0.201^{* *}$ & 3.710 & $-1.295 \mathrm{E}-02$ & $-0.238^{* *}$ & -3.440 \\
\hline Hispanic $\%$ & $3.726 \mathrm{E}-02$ & $0.206^{*}$ & 2.482 & $-4.84 \mathrm{E}-03$ & -0.126 & -1.182 \\
\hline Female $\%$ & $5.035 \mathrm{E}-02$ & 0.046 & 1.339 & 2.613E-03 & 0.010 & 0.224 \\
\hline Pretrial Release $\%$ & $5.930 \mathrm{E}-03$ & 0.023 & 0.692 & $-5.75 \mathrm{E}-03$ & $-0.091^{*}$ & -2.162 \\
\hline Counsel Private $\%$ & $-5.85 \mathrm{E}-03$ & -0.019 & -0.454 & $7.147 \mathrm{E}-03$ & 0.094 & 1.786 \\
\hline Counsel FPD \% & $1.708 \mathrm{E}-02$ & 0.073 & 1.626 & $-2.76 \mathrm{E}-03$ & -0.049 & -0.847 \\
\hline Counsel CJA \% & $-6.32 \mathrm{E}-03$ & -0.022 & -0.556 & $-1.10 \mathrm{E}-03$ & -0.016 & -0.311 \\
\hline Criminal History & $5.186 \mathrm{E}-03$ & $0.125^{* *}$ & 3.331 & $-1.14 \mathrm{E}-03$ & $-0.114^{*}$ & -2.361 \\
\hline \multicolumn{7}{|l|}{ Points, Average } \\
\hline Career Criminal & $7.542 \mathrm{E}-02$ & 0.033 & 0.922 & $-3.38 \mathrm{E}-02$ & -0.064 & -1.407 \\
\hline \multicolumn{7}{|l|}{ Enhancement \% } \\
\hline \multicolumn{7}{|l|}{ Crime Type Factors: } \\
\hline $\begin{array}{l}\text { Offense Level, } \\
\text { Average }\end{array}$ & $-9.96 \mathrm{E}-03$ & $-0.521^{* *}$ & -11.583 & $7.138 \mathrm{E}-04$ & $0.154^{* *}$ & 2.673 \\
\hline Drug Crime \% & $-2.49 \mathrm{E}-02$ & -0.070 & -1.473 & $7.076 \mathrm{E}-03$ & 0.082 & 1.346 \\
\hline Violent Crime \% & $-3.83 \mathrm{E}-02$ & -0.033 & -1.087 & $1.524 \mathrm{E}-02$ & 0.054 & 1.394 \\
\hline Theft-Fraud Crime $\%$ & $-5.89 \mathrm{E}-02$ & $-0.145^{* *}$ & -3.253 & $8.137 \mathrm{E}-03$ & 0.083 & 1.446 \\
\hline Weapon Crime $\%$ & -0.131 & $-0.129^{* *}$ & -3.870 & $1.237 \mathrm{E}-02$ & 0.050 & 1.177 \\
\hline Immigration Crime $\%$ & $-1.47 \mathrm{E}-02$ & -0.048 & -0.612 & $-1.08 \mathrm{E}-02$ & -0.144 & -1.454 \\
\hline
\end{tabular}


Table 3 (cont'd)

\begin{tabular}{|c|c|c|c|c|c|c|}
\hline & \multicolumn{3}{|c|}{ Guilty Plea \% } & \multicolumn{3}{|l|}{ Acquittal \% } \\
\hline & Coefficient & Standardized & $\mathbf{t}$ & Coefficient & Standardized & $\mathbf{t}$ \\
\hline \multicolumn{7}{|l|}{ Plea Discount Factors: } \\
\hline $\begin{array}{l}\text { Substantial Assistance } \\
\text { Departure \% }\end{array}$ & $8.117 \mathrm{E}-02$ & $0.117^{* *}$ & 5.591 & $-2.18 \mathrm{E}-02$ & $-0.196^{* *}$ & -4.840 \\
\hline $\begin{array}{l}\text { Acceptance of } \\
\text { Responsibility \% }\end{array}$ & 0.260 & $0.663^{* *}$ & 15.952 & $-3.99 \mathrm{E}-02$ & $-0.418^{* * *}$ & -7.870 \\
\hline $\begin{array}{l}\text { Judicial Downward } \\
\text { Departure \% }\end{array}$ & $3.097 \mathrm{E}-03$ & 0.010 & 0.233 & $-1.48 \mathrm{E}-03$ & -0.020 & -0.360 \\
\hline $\begin{array}{l}\text { Prison \%, } \\
\text { Trial Differential }\end{array}$ & $5.471 \mathrm{E}-02$ & $0.111^{* *}$ & 3.562 & $-2.86 \mathrm{E}-02$ & $-0.239^{* *}$ & -5.992 \\
\hline $\begin{array}{l}\text { Prison Duration, } \\
\text { Trial Differential } \\
\end{array}$ & $5.554 \mathrm{E}-05$ & $0.052^{*}$ & 2.226 & $-7.48 \mathrm{E}-06$ & -0.029 & -0.965 \\
\hline \multicolumn{7}{|l|}{ Regional Factors: } \\
\hline 1st Circuit & $9.453 \mathrm{E}-03$ & 0.027 & 0.995 & $7.022 \mathrm{E}-03$ & $0.084^{*}$ & 2.381 \\
\hline 2d Circuit & $2.089 \mathrm{E}-02$ & $0.125^{* *}$ & 3.592 & $-1.20 \mathrm{E}-03$ & -0.030 & -0.666 \\
\hline 3d Circuit & $2.942 \mathrm{E}-05$ & 0.000 & 0.015 & $2.056 \mathrm{E}-03$ & 0.041 & 1.070 \\
\hline 4th Circuit & $-1.16 \mathrm{E}-02$ & $-0.087^{*}$ & -2.165 & $5.517 \mathrm{E}-03$ & $0.171^{* *}$ & 3.316 \\
\hline 6th Circuit & $-1.15 \mathrm{E}-04$ & -0.001 & -0.022 & $5.882 \mathrm{E}-03$ & $0.149^{* *}$ & 3.616 \\
\hline 7th Circuit & $-1.84 \mathrm{E}-03$ & -0.008 & -0.310 & $-3.38 \mathrm{E}-03$ & -0.063 & -1.829 \\
\hline 8th Circuit & $2.994 \mathrm{E}-03$ & 0.016 & 0.520 & $2.799 \mathrm{E}-03$ & 0.062 & 1.567 \\
\hline 9th Circuit & $1.831 \mathrm{E}-02$ & $0.173^{* *}$ & 3.256 & $-3.25 \mathrm{E}-03$ & -0.130 & -1.862 \\
\hline 10th Circuit & $1.269 \mathrm{E}-02$ & $0.071^{*}$ & 2.372 & $-3.48 \mathrm{E}-04$ & -0.080 & -0.210 \\
\hline 11th Circuit & $-1.96 \mathrm{E}-02$ & $-0.140^{*}$ & -4.360 & $8.093 \mathrm{E}-03$ & $0.238^{* *}$ & 5.810 \\
\hline Constant & 0.943 & & 51.606 & $3.460 \mathrm{E}-02$ & & 6.096 \\
\hline Adjusted R Square & 0.663 & & & 0.449 & & \\
\hline
\end{tabular}

$$
\mathrm{N}=704, * * \mathrm{p}<0.01, * \mathrm{p}<0.05
$$

\section{B. Trials and Tribulations by the Numbers}

For readers unfamiliar with regression analysis, a brief guide is in order. The key entries in Table 3 appear in bold under the "Standardized" column for each of the two studies (one for guilty pleas and one for acquittals). The standardized coefficient allows a reader to compare the relative size of the impact that various factors have on the dependent variable. ${ }^{206}$ A larger standardized coefficient (either in a positive or negative direction) indicates a stronger effect of that

${ }^{206}$ See FINKELSTEIN \& LEVIN, supra note 171, at 324 (explaining how to interpret coefficients). 
variable on guilty pleas or acquittals in the districts. The positive or negative sign of each standardized coefficient is also worth noting: a negative sign means that when the independent variable in that row increases, guilty plea rates decrease (or acquittal rates decrease for the right-hand column of standardized coefficients). A positive sign means that when the factor in question increases, guilty plea or acquittal rates also increase. The variables worthy of attention appear in bold typeface; they produced effects clear enough to leave us confident that the patterns were not merely a product of chance.

The variables that deserve attention first are those that demonstrate a statistically significant impact on both guilty plea and acquittal rates. Two such variables offer some of the most clear-cut signs of prosecutor influence. The first is the enhanced three-point "acceptance of responsibility" sentence discount (or "super AR" for short). The connection between guilty pleas and an ordinary two-point AR discount is not surprising, as virtually all defendants who plead guilty receive the discount and virtually none who lose at trial receive it. ${ }^{207}$ But federal prosecutors powerfully influence the super AR discount; until recently, the guideline language required the defendant to provide "timely" and "complete" information to the government "concerning his own involvement in the offense." to be early enough to permit the government to avoid trial preparation. For all these preconditions to the award of the extra discount, the court relied on factual representations from the government. ${ }^{209}$ As Table 3 shows, in districts where the prosecutors more frequently request this discount, guilty plea rates tend to be higher. Even more revealing is the conclusion that acquittal rates tend to be lower in districts where super AR is used heavily.

"Substantial assistance" departures also affect both the guilty plea and acquittal rates. The positive effect on guilty plea rates confirms other scholars' work showing how prosecutors use these departures to encourage guilty pleas. ${ }^{210}$ Even more dispiriting is the effect of sub-

207 See supra text accompanying notes 156-57.

208 See U.S. SENTENCING GUIDELINES MANUAL § 3E.1(b)(1) (2002) (allowing an additional level of sentence discount).

209 See U.S. SENTENCING GUIDELINES MANUAL § 3E1.1(b) (2004) (requiring motion from the government). This guideline was amended to allow the third discount level in 1992. In 2003, Congress directly amended this provision to place control of the discount completely in the hands of the prosecution.

${ }^{210}$ See Frank O. Bowman, III, Departing Is Such Sweet Sorrow: A Year of Judicial Revolt on "Substantial Assistance" Departures Follows a Decade of Prosecutorial Indiscipline, 29 STETSON L. REV. 7, 13-16 (1999) (showing that defendants are more willing to cooperate with the government when the government files more substantial assistance motions). 
stantial assistance departures on acquittal rates: districts with high levels of such departures also tended to show lower rates of acquittals. Prosecutors are not using their substantial assistance departures only to avoid the easy trials where a conviction was nearly inevitable.

The contrast between the effects of prosecutor versus judicial departures is instructive. The rate of judicial downward departures in a district had no significant effect on either guilty plea or acquittal rates in the district. These departure variables, when combined, give us some reason to believe that prosecutor choices matter more than judicial choices in setting the price of trials.

Another variable offers an unobstructed view of trial distortion at work: the differential between the percentage of prison sentences imposed after trial and after a guilty plea. According to Table 3, districts with a larger differential in the percentage of prison sentences imposed (that is, districts with a larger average plea discount) were likely to have lower acquittal rates and higher guilty plea rates. Even after controlling for type of crime, offense level, and other features of a district's caseload, the prospects of receiving a prison sentence after trial remained an important influence on the decision by defendants to give up their defenses. ${ }^{211}$ For the last decade in the federal system, inducements like these were effective in the weakest cases where juries might otherwise have acquitted.

A pair of variables, when considered together, sheds further light on prosecutor influence: the average offense level for crimes in the district, and the average criminal history points assigned to convicted defendants in the district. These outcomes deserve special attention because they run in opposite directions, both for guilty pleas and acquittals. Higher offense levels generate lower guilty plea rates, while higher criminal history scores lead to higher guilty plea rates. Conversely, higher offense levels send acquittal rates up, but higher criminal history scores drive acquittal rates down.

This pattern is meaningful because prosecutors have more control over offense levels than offender criminal history. Through the relevant conduct rules, prosecutors choose whether or not to marshal the evidence for factual findings that increase the range permitted by the guidelines. The offender's criminal history, which the court is more likely to figure into a defendant's sentence regardless of the prosecutor's choices in constructing the case, has effects more consistent with

${ }^{211}$ A related measure of sentence severity, the difference between the length of prison terms imposed after guilty pleas and the length of terms imposed after trial, significantly influenced guilty pleas but not acquittals. 
the accuracy hypothesis. Districts that process defendants who present more serious criminal histories also produce lower acquittal rates, suggesting that judges and prosecutors in these districts value quality over quantity and put extra effort into avoiding acquittals for these high-priority defendants. ${ }^{212}$

Just the opposite, however, holds true for offense levels. The districts with the highest average offense levels also had the lowest guilty plea rates and highest acquittal rates. If prosecutors in these districts simply faced more objectively serious criminal conduct, an increasingly accurate system would require prosecutors to prioritize resources to these cases and drive the acquittal rates down. Lower offense levels produce higher guilty plea rates, suggesting that prosecutors in these districts work with defendants to reduce the offense level calculations under the guidelines to induce a guilty plea.

The criminal caseloads of prosecutors and judges mattered less over the last decade than they did over the longer period considered in Part III. After controlling for other features of the cases on a district's docket, the prosecutors' caseloads in a district did not affect either the guilty plea or acquittal rate. Heavier judicial criminal caseloads and longer trials (a proxy for the complexity of cases) both had a negative effect on guilty plea rates, but no significant effect on acquittal rates. These variables might identify districts where local attitudes are more favorable to trials (thus producing higher weighted judicial workloads and lower guilty plea rates simultaneously). There is not much evidence here to suggest that judges are influencing guilty plea rates, be it out of concern for docket control or for other reasons. ${ }^{213}$

Two variables relating to defendant demographics also tip the scales towards a trial distortion theory. Black defendants were less likely than white defendants to be acquitted and more likely to plead guilty, holding other caseload features constant. Districts with more Hispanic defendants also had higher levels of guilty pleas. Given the limited number of defendant characteristics captured in this model, the defendant's race or ethnicity might reflect differences of income,

${ }^{212}$ See supra Part II.C.3 for an explanation of the relationship between quality and quantity in criminal case processing.

${ }^{213}$ As Table 3 shows, more pretrial releases in a district lead to fewer acquittals (even though the defendant is available to assist with the defense). One might interpret this finding as good news: federal prosecutors, to their credit, are not taking any tactical advantages that might arise from a defendant being detained before trial. 
education, or other personal characteristics. ${ }^{214}$ Still, the race and ethnicity variables do suggest that offender demographics influence plea negotiations and outcomes, which is consistent with studies that have focused more closely on how these factors distort the operation of more legally relevant factors. ${ }^{215}$

Statistics about the litigation resources and outcomes for each of the federal districts give us only a partial view of the rich reality of federal courthouses; this view, however, is from a new vantage point that allows a view of things not easily visible from ground level. The statistics on court resources and outcomes tell us that dropping acquittal rates over the last decade in federal court is a valid cause of concern. The acquittal trend reveals a system that probably distorts trial outcomes and produces less reliable results than it once did. The devices available to offer defendants a large and certain sentence discount for waiving trial-particularly those devices largely in the control of prosecutors-have come to dominate the practice of criminal law in the federal courts.

\section{The Sentencing Law Nexus}

What guidance can this survey offer about the reforms needed to prevent the distortions from expected outcomes at trial? Most conversations about plea bargains eventually return to sentencing laws and practices, and this one is no exception. Most of the devices that drive down acquittal rates are grounded in sentencing laws; hence, the best strategy for improving the reliability and public legitimacy of plea bargains should focus on the nexus between plea bargains and sentencing.

These are times for taking stock in federal sentencing. The Supreme Court, in Blakely $v$. Washington, ${ }^{216}$ overturned a state sentencing system that allowed a judge rather than a jury to find facts necessary to increase the authorized sentence. In Booker $v$. United States, the Supreme Court applied this holding to the federal sentencing guidelines and restructured the statutes to require district court judges to use the guidelines on an "advisory" basis, leaving the judges free to impose a sentence outside the guidelines if such an outcome would better serve

\footnotetext{
${ }^{214}$ It would be especially important to study case-level data before drawing strong inferences from a finding about race and acquittals, and this study relies on districtlevel data.

${ }^{215}$ See, e.g., Albonetti, supra note 194 (analyzing the relationship between race and guilty plea rates).

${ }^{216} 124$ S. Ct. 2531, 2543 (2004).
} 
the statutory purposes of sentencing. ${ }^{217}$ The sentence that a trial judge imposes is still subject to appellate review, and can be overturned if the sentence is "unreasonable." 218

This is not the place for an analysis of Blakely or Booker as a matter of constitutional law or of sound sentencing policy. ${ }^{219}$ The importance of these cases for our purposes is the upheaval they caused. Congress is now considering fundamental changes in the federal sentencing laws-changes that the Supreme Court forced to the top of the legislative agenda. ${ }^{220}$ Attention to guilty pleas should now inform any wholesale revisions to federal sentencing law that occur during this unexpected effort of redesigning the system.

The main threats to healthy federal guilty plea practices are sentencing and charging practices that increase the size and certainty of the trial penalty. To the extent that a guilty plea becomes a prerequisite to receiving a particular form of sentence discount, that discount undercuts the power of the trial to uncover the truth. Furthermore, the best way to judge the tendency of a sentencing discount to influence the trial penalty is to check who controls the discount. The historical and statistical analyses in Parts III and IV support the commonsense inference that federal prosecutors in our current system affect the trial penalty more than judges do. Therefore, the most important target in reforming sentencing law should be rules that currently give prosecutors monopoly power to link sentence discounts to the defendant's choice to plead guilty.

Two examples of such rules are the enhanced discount for acceptance of responsibility and downward departures based on a defendant's substantial assistance to the government in other investigations.

${ }^{217} 125$ S. Ct. 738, 768 (2005) (loosening the binding power of the sentencing guidelines).

${ }^{218} I d$. at 766 ("Those factors [listed in the sentencing guidelines] in turn will guide appellate courts, as they have in the past, in determining whether a sentence is unreasonable.").

${ }_{219}$ See generally Stephanos Bibas, Originalism and Formalism in Criminal Procedure: The Triumph of Justice Scalia, the Unlikely Friend of Criminal Defendants?, 94 GEO. L.J. (forthcoming Nov. 2005), available at http://papers.ssrn.com/so13/ papers.cfm?abstract_id=763804 (discussing Blakely and Booker as examples of a distinctive style of constitutional reasoning); Nancy J. King \& Susan R. Klein, Beyond Blakely, 16 FED. SENT'G REP. 316 (June 2004) (discussing Blakely's impact on the sentencing guidelines); Steven Chanenson, The Next Era of Sentencing Reform, 54 EMORY L.J. 377 (2005) (discussing criminal sentencing in light of Blakely).

220 See Posting of Douglas A. Berman to Sentencing Law and Policy, A Bit of Booker Fix Buzz, http://sentencing.typepad.com/sentencing_law_and_policy/2005/10/ a_bit_of_booker.html (Oct. 2, 2005, 4:29 PM) (discussing an imminent congressional response to Booker). 
For the latter discounts, the law grants the prosecutor sole power to award the discount, ${ }^{221}$ while in the case of acceptance of responsibility discounts, the prosecutor has always been powerfully persuasive. ${ }^{222} \mathrm{Al}-$ though the prosecutor's basis for awarding these discounts is often opaque, it is clear to most defendants that a guilty plea is a necessary condition. Restoring some judicial control over these sentence discounts could weaken their link to guilty pleas, making them more available to defendants with the temerity to exercise constitutional trial rights.

The remedy cobbled together by five Justices in Booker, while odd as a matter of severability doctrine, might be successful in policy terms. It could shift federal plea practices away from the worst dangers of trial distortion. The basic thrust of the "advisory guidelines" system is to reassert the authority of the sentencing judge and to make less certain the prosecutor's control over the means of delivering a trial penalty. Districts will not move uniformly, but on the whole they could move in the direction of a more balanced exercise of sentencing power.

The advisory guidelines envisioned in Booker will probably not, however, create a stable platform for federal sentencing. Congress is likely to restructure the system, and the options are plentiful: "guidelines without lids," a streamlined set of aggravating facts, or a collec-

${ }^{221}$ U.S. SENTENCING Guidelines MANUAL § 5K1.1 (2004) (permitting courts to depart from guidelines upon motion by the government due to defendant's assistance in other matters); United States v. Wade, 504 U.S. 181, 187 (1992) (explaining that a defendant's assistance does not guarantee such a departure from the guidelines, but that any departure is within the prosecutor's discretion).

${ }^{222}$ U.S. SENTENCING GUIDELINES MANUAL § 3E1.1(b) (2004) (permitting prosecutors to further decrease a sentence due to assistance when the defendant has clearly demonstrated acceptance of responsibility). The 2003 Feeney Amendment solidified prosecutor control over the three-point acceptance of responsibility discounts, already a crucial cause of displaced acquittals. See Michael M. O'Hear, Cooperation and Accountability After the Feeney Amendment, 16 FED. SENT'G REP. 102 (Dec. 2003) (arguing for expanded Justice Department control over the acceptance of responsibility discount). For instance, the 2003 law also empowered prosecutors to designate certain "fast-track" districts for the use of special sentence discounts that would increase the volume of guilty pleas. See Prosecutorial Remedies and Other Tools to End the Exploitation of Children Today (PROTECT) Act $\$ 401$ (d) (2) (2003) (establishing a de novo appellate standard of review for downward but not for upward departures); id. § 401(m) (2) (A) (instructing the Sentencing Commission to place further limits on downward departures); id. § 401(1) (2) (A) (mandating that downward departures and name of sentencing judge be reported to House and Senate Judiciary Committees). 
tion of mandatory minimum penalties superimposed on the advisory guidelines. ${ }^{223}$

In this Article, I have not addressed the impact of mandatory minimum penalties on guilty plea practices, ${ }^{224}$ but these laws invoke familiar themes regarding prosecutorial monopoly power over sentence discounts. Mandatory minimum sentence laws exert a powerful pull on plea negotiations, because a prosecutor's promise not to file (or to dismiss) charges that carry a mandatory minimum penalty can create enormous gaps in the sentence imposed and enormous incentives to plead guilty. ${ }^{225}$ Mandatory minimum sentences might become the rule rather than the exception in the federal system as Congress reconstructs the sentencing system in the aftermath of Blakely and Booker, ${ }^{226}$ but legislators who care about accuracy in criminal justice should look to alternatives.

Healthy revisions to the sentencing laws should give judges the authority to second-guess the prosecutor's desire to discount sentences and induce a guilty plea. Yet there is a danger in such proposals, in that they put upward pressure on federal sentences. The strategy of increasing the authority of judges to counterbalance prosecutors means that judges will reject more sentence discounts. In a federal system that many (myself included) consider to be too severe already, this might be too high a price to pay for a more accurate system that values innocence.

At the end of the day, it may become necessary to address severe sentences directly. Legislatures often create high maximum sentences

${ }^{223}$ See Postings of Douglas A. Berman to Sentencing Law and Policy, Topical Archive: Legislative Reactions to Booker and Blakely, http://sentencing.typepad.com/ sentencing_law_and_policy/legislative_reactions_to_booker_and_blakely (relating and evaluating possible legislative changes to the sentencing system).

${ }^{224}$ See supra note 200 for a discussion of why the study in Part IV does not include mandatory minimum charging as an independent variable.

${ }^{225}$ See Justice KenNedy COMM'N, AM. BAR Ass'N, REPORTS WITH RECOMMENDATIONS 26-27 (2004), http://www.abanet.org/crimjust/kennedy/ JusticeKennedyCommissionReportsFinal.pdf; Ian Weinstein, Fifteen Years After the Federal Sentencing Revolution: How Mandatory Minimums Have Undermined Effective and Just Narcotics Sentencing, 40 AM. CRIM. L. REV. 87, 97 (2003) (“[P]rosecutors exercise significant control of sentence length through charging decisions and use sentencing phase mitigation to give the appearance of mitigation to induce pleas."); Stephen J. Schulhofer, Rethinking Mandatory Minimums, 28 WAKE FOREST L. REV. 199, 202 (1993) ("Mandatories then become little more than a bargaining chip, a 'hammer' which the prosecutor can invoke at her option, to obtain more guilty pleas under more favorable terms.").

${ }^{226}$ See Keith Perine, 'Heightened Tensions' Fray Judicial-Legislative Relations, CQ WEEKLY, Sept. 18, 2004, at 2148 (addressing congressional concerns about using mandatory minimums in response to "activist judges"). 
with the express intention of giving prosecutors a "bargaining chip" to produce more guilty pleas. ${ }^{227}$ An overall reduction in the severity of authorized federal punishments would squeeze down the plea discount that the prosecutor could offer. That would translate into guilty pleas that do not target the weak cases destined for dismissal or acquittal. Less room for discounting sentences during plea negotiations leaves more room for truth to prosper.

\section{CONCLUSION}

Although the lessons for federal criminal justice are profound, the power of plea bargaining practices to displace acquittals and distort the truth-finding function of trials is not strictly a federal problem. The same can and does happen in state criminal justice, where the great bulk of criminal matters in the United States are processed. ${ }^{228}$ The voting public in each state invests large amounts of public funds in criminal justice systems, and expects those systems to uncover the truth.

There are reasons to think the problems of trial distortion are at least as important at the state level as in the federal courts. Lower olume courts dealing with the most serious crimes are said to be the places where trials still matter. The federal courts-which process far more felonies than misdemeanors-are thought to epitomize this sort of system. The caseload for the federal prosecutors, defense attorneys, and judges is less crushing than the caseload for their state counterparts. While plea bargaining is recognized as the most important method for disposing of cases even in the federal system, the federal criminal trial is still thought to cast a long shadow.

On the other hand, in higher volume courts at the lowest levels of the state court systems, trials almost never happen. Those cases almost always result in guilty pleas. In addition, there is only limited conversation between attorneys about how to resolve the case, because the "going rate" for each crime, committed by a defendant with a particular criminal record, is well established. ${ }^{229}$ Given the huge volume chips).

${ }^{227}$ See supra note 94 and accompanying text (discussing prosecutors' bargaining

${ }^{228}$ See Marc L. Miller, A Map of Sentencing and a Compass for Judges: Sentencing Information Systems, Transparency, and the Next Generation of Reform, 105 COLUM. L. REV. 1351, 1362-63 (2005) (articulating the need to gather state-level data that distinguishes between guilty pleas and convictions or acquittals).

${ }^{229}$ See Malcolm M. Feeley, Pleading Guilty in Lower Courts, 13 LAW \& SOC'Y REV. 461, 463 (1979) (“[A] case whose outcome has been the result of vigorous bargaining or trial can establish a new 'going rate' for subsequent similar cases.”). 
of cases involved and the limited scrutiny each receives, there is little reason to hope that the outcomes of plea negotiations come close to replicating the outcomes that a trial would produce. The federal system, for all its problems, is probably not alone in punishing trials so severely that the results do not deserve public confidence.

The relationship between acquittal rates and guilty plea rates is especially relevant for those who still hope to blunt the power of the plea bargain and to give force instead to the public's negative views on bargain justice. Some forms of bargain justice are more harmful than others, and the critical task is to find economical ways of targeting and disposing of the greatest harms.

In the absence of sorting techniques such as the one developed here, we can only speak in bromides about the coercion inherent in plea negotiations, but we cannot easily differentiate among concrete plea practices in specific times and places. When no shorthand method of evaluation is available, we are left waiting for exhaustive case-by-case studies based on the knowledge of local insiders, and we must suspend moral judgment in the meantime. ${ }^{230}$ Accessible but non-definitive measures, such as the warning signals from the drop in acquittals, cure this paralysis. Such a warning gives voice to those willing to speak against possible injustice, even if the definitive proof of injustice in specific cases never arrives.

${ }^{230}$ See Schulhofer \& Nagel, supra note 159, at 1297, for one of the few examples of detailed evaluations of plea bargaining practices, based on rare levels of cooperation from ten U.S. Attorney's Offices. 
APPENDIX

Table A-1: Regression of Annual Guilty Plea and Acquittal Rates on Factors Related to Caseload and Crime Types in Federal Criminal Cases, 1945-2002

\begin{tabular}{|c|c|c|c|c|c|c|}
\hline & $\begin{array}{l}\text { Guilty Plea } \\
\text { Coefficient }\end{array}$ & Standardized & $\mathbf{t}$ & $\begin{array}{l}\text { Acquittal \% } \\
\text { Coefficient }\end{array}$ & Standardized & $\mathbf{t}$ \\
\hline Number of AUSAs & $5.411 \mathrm{E}-05$ & $2.001 * *$ & 7.176 & $-1.22 \mathrm{E}-05$ & $-1.855^{* *}$ & -7.001 \\
\hline $\begin{array}{l}\text { Number of } \\
\text { District Judges }\end{array}$ & $-3.30 \mathrm{E}-04$ & $-1.163 * *$ & -3.032 & $7.818 \mathrm{E}-05$ & $1.131 * *$ & 3.100 \\
\hline $\begin{array}{l}\text { Criminal Case } \\
\text { Volume }\end{array}$ & $1.845 \mathrm{E}-07$ & 0.056 & 0.259 & $2.525 \mathrm{E}-07$ & 0.313 & 1.531 \\
\hline $\begin{array}{l}\text { Civil and Criminal } \\
\text { Cases per Judge }\end{array}$ & $-8.51 \mathrm{E}-06$ & -0.017 & -0.190 & $-3.52 \mathrm{E}-05$ & $-0.285^{* *}$ & -3.399 \\
\hline $\begin{array}{l}\text { Average Days } \\
\text { per Trial }\end{array}$ & $2.38 \mathrm{E}-02$ & 0.339 & 1.327 & $-4.90 \mathrm{E}-03$ & -0.287 & -1.179 \\
\hline Narcotics Case $\%$ & -0.173 & -0.501 & -1.346 & $1.188 \mathrm{E}-02$ & 0.141 & 0.400 \\
\hline Immigration Case \% & 0.251 & $0.520 * *$ & 4.915 & $-5.11 \mathrm{E}-02$ & $-0.434 * *$ & -4.318 \\
\hline Fraud-Theft Case \% & $6.656 \mathrm{E}-02$ & 0.108 & 0.964 & $-7.92 \mathrm{E}-03$ & -0.053 & -0.495 \\
\hline Constant & 0.792 & & 19.341 & $5.031 \mathrm{E}-02$ & & 5.304 \\
\hline Adjusted R Square & 0.793 & & & 0.813 & & \\
\hline
\end{tabular}

$$
\mathrm{N}=58, * * \mathrm{p}<0.01, * \mathrm{p}<0.05 \quad[\text { Model N6] }
$$

The model relies on estimates for the number of Assistant U.S. Attorneys for the years 1945-1957, when Department of Justice annual reports do not publish the number. Assuming some modest growth over time, the model sets the number at 500 for 1945-1950, and at 540 for 1951-1957. "Civil and criminal cases per AUSA" was calculated by adding the number of criminal cases terminated to the number of civil cases terminated in which the United States appeared as a party, and dividing the total by the number of prosecutors for each year. "Civil and criminal cases per judge" was calculated by adding the total number of criminal cases and civil cases terminated each year, and dividing by the number of district court judges on the bench for that year. 